\title{
Application of Hastelloy $X$ in Gas-Cooled Reactor Systems
}

\author{
C. R. Brinkman \\ P. L. Rittenhouse \\ W. R. Corwin \\ J. P. Strizak \\ A. Lystrup \\ J. R. DiStefano
}

\section{OAK RIDGE NATIONAL LABORATORY}




\section{DISCLAIMER}

This report was prepared as an account of work sponsored by an agency of the United States Government. Neither the United States Government nor any agency Thereof, nor any of their employees, makes any warranty, express or implied, or assumes any legal liability or responsibility for the accuracy, completeness, or usefulness of any information, apparatus, product, or process disclosed, or represents that its use would not infringe privately owned rights. Reference herein to any specific commercial product, process, or service by trade name, trademark, manufacturer, or otherwise does not necessarily constitute or imply its endorsement, recommendation, or favoring by the United States Government or any agency thereof. The views and opinions of authors expressed herein do not necessarily state or reflect those of the United States Government or any agency thereof. 


\section{DISCLAIMER}

Portions of this document may be illegible in electronic image products. Images are produced from the best available original document. 
Printed in the United States of America. Available from

National Technical Information Service

U.S. Department of Commerce

5285 Port Royal Road, Springfield, Virginia 22161

Price: Printed Copy \$4.50; Microfiche $\$ 2.25$

This report was prepared as an account of work sponsored by the United States Government. Neither the United States nor the Energy Research and Development Administration/United States Nuclear Regulatory Commission, nor any of their employees, nor any of their contractors, subcontractors, or their employees, makes any warranty, express or implied, or assumes any legal liability or responsibility for the accuracy, completeness or usefulness of any information, apparatus, product or process disclosed, or represents that its use would not infringe privately owned rights. 
Contract No. W-7405-eng-26

METALS AND CERAMICS DIVISION

HTGR BASE PROGRAM

(189a No. OHO34)

C. R. Brinkman, P. L. Rittenhouse, W. R. Corwin,

J. P. Strizak, A. Lystrup, and J. R. DiStefano

Date Published: October 1976

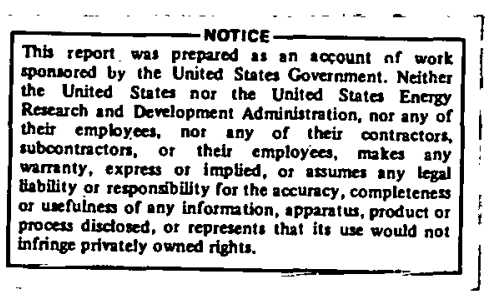

OAK RIDGE NATIONAL LABORATORY

Oak Ridge, Tennessee 37830 operated by

UNION CARBIDE CORPORATION

FOR THE

ENERGY RESEARCH AND DEVELOPMENT ADMINISTRATION 


\section{THIS PAGE}

\section{WAS INTENTIONALLY \\ LEFT BLANK}


CONTENTS

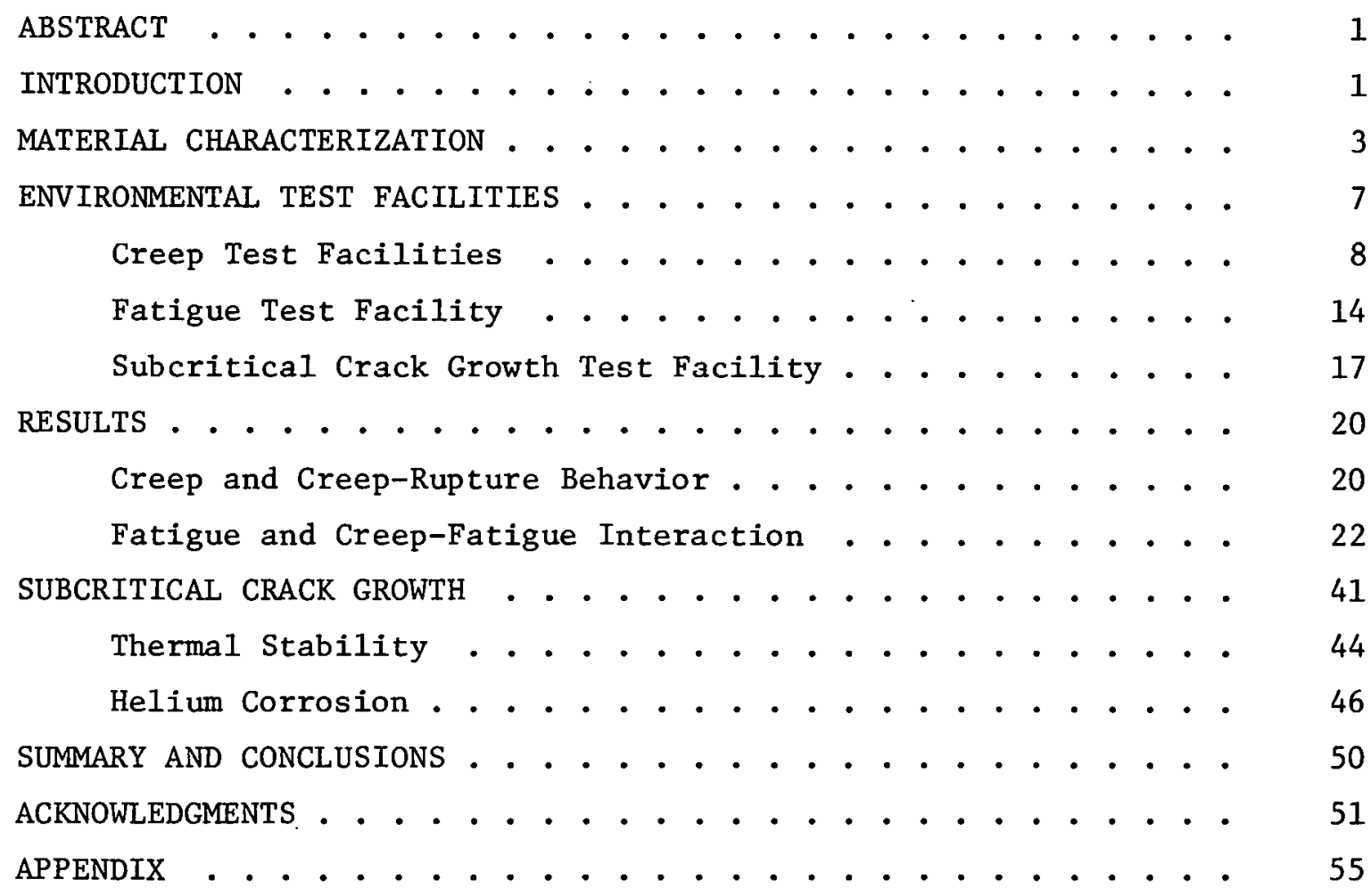




\title{
APPLICATION OF HASTELLOY X IN GAS-COOLED REACTOR SYSTEMS
}

C. R. Brinkman, P. L. Rittenhouse, W. R. Corwin, J. P. Strizak, and A. Lystrup ${ }^{\mathrm{I}}$

\begin{abstract}
Hastelloy $\mathrm{X}$, an Ni-Cr-Fe-Mo alloy, may be an important structural alloy for components of gascooled reactor systems. Expected applications of this alloy in the High-Temperature Gas-Cooled Reactor (HTGR) are discussed, and the development of interim mechanical properties and supporting data are reported. Properties of concern include tensile, creep, creep-rupture, fatigue, creep-fatigue interaction, subcritical crack growth, thermal stability, and the influence of helium environments with controlled amounts of impurities on these properties. In order to develop these properties in helium environments that are expected to be prototypic of HTGR operating conditions, it was necessary to construct special environmental test systems. Details of construction and operating parameters are described. Interim results from tests designed to determine the above properties are presented. To date a fairly extensive amount of information has been generated on this material at Oak Ridge National Laboratory and elsewhere concerning behavior in air, which is reviewed. Howevcr, only limited data are available from tests conducted in helium. Comparisons of the fatigue and subcritical growth behavior in air between Hastelloy $\mathrm{X}$ and a number of other structural alloys are given.
\end{abstract}

\section{INTRODUCTION}

Hastelloy $\mathrm{X}$, an Ni-Cr-Fe-Mo alloy (nominally 47, 22, 19 and 9\%, respectively, by weight), has been used successfully for more than two decades in a variety of elevated-temperature appllcations requiring high strength. It is essentially a single-phase alloy with a face-centered cubic structure and obtains its strength primarily by solid-solution strengthening from the elements $\mathrm{Cr}$, Mo, and $\mathrm{W}$. Some strengthening may also be due to the presence of carbide precipitates. Moreover, because of the high chromium content, it shows excellent resistance to oxidation to temperatures of about $982^{\circ} \mathrm{C}\left(1800^{\circ} \mathrm{F}\right)$ and higher. Perhaps its most

${ }^{1}$ On temporary assignment from the Danish Atomic Energy Commission, Metallurgy Department. 
common usage has been in gas turbine engines, where it has been employed in sheet components. The specifications for this material are covered ${ }^{2,3}$ in SB-435 of Sect. II and Sect. VIII of the ASME BPVC, and in Part 7 of ASTM Standards. ${ }^{4}$ It is also approved for use to $900^{\circ} \mathrm{C}\left(1650^{\circ} \mathrm{F}\right)$ under Case 1321-2 (Special Ruling) to Sect. VIII, in unfired pressure vessels. Hastelloy $X$ is not covered under Sect. III.

In the most recent design of the steam-cycle High-Temperature GasCooled Reactor (HTGR), Hastelloy $X$ was chosen for fabrication of the lower cross ducts, which connect the exit of the reactor core to the steam generators. Similarly, the upper cross ducts, which return the helium to the core, will also be constructed of Hastelloy X. A number of product forms (i.e., plate for the hot duct itself and its thermal barrier cover plates, sheet, bar, and forgings) are also of interest. ${ }^{5}$ The nominal design temperature for the hot duct is $788^{\circ} \mathrm{C}\left(1450^{\circ} \mathrm{F}\right)$, with the possibility of temperature streaking (short term and random in position around the duct) up to $927^{\circ} \mathrm{C}\left(1700^{\circ} \mathrm{F}\right)$. Design lifetime is $280,000 \mathrm{hr}$ in an environment of continuously recirculated and purified helium containing very low levels of impurity gases such as $\mathrm{H}_{2} \mathrm{O}, \mathrm{CO}, \mathrm{CH}_{4}$, and $\mathrm{H}_{2}$. The current technical specification limits the total content of oxidizing (oxygen-containing) species to $10 \mathrm{ppm}$ with an upper design basis limit of about $500 \mathrm{ppm}$. The full-life fluence expected on the hot duct is no greater than $10^{18}$ neutrons $/ \mathrm{cm}^{2}$.

The design for the direct-cycle (gas turbine) HTGR also proposes the use of Hastelloy $\mathrm{X}$, at a nominal temperature of $816^{\circ} \mathrm{C}\left(1500^{\circ} \mathrm{F}\right)$, in the ducts from the reactor core exit to the turbomachinery. Other design considerations for this use would be quite similar to those discussed above for the steam-cycle HTGR. Finally, Hastelloy $X$ is one of the candidate materials for components of gas-cooled reactor processheat plants (VHTR), which are expected to have application in the future for providing heat for coal conversion processes (e.g., hydrogasification, solution hydrocracking, and steam gasification), steel making, etc. In such systems, Hastelloy $\mathrm{X}$ might be used (depending upon temperature, stress, environment, etc.) for ducting or the tube or support-plate material of the intermediate and process-heat exchangers.

${ }^{2} A S M E$ Boiler and Pressure Vessel Code, Section II: Materials Specifications, Part B-Nonferrous, The American Society of Mechanical Engineers, New York, 1971.

${ }^{3}$ ASME Boiler and Pressure Vessel Code, Section VIII: Pressure Vessels, Division 2 -Altermate Rules, The American Society of Mechanical Engineers, New York, 1971.

${ }^{4} 1972$ Annual Book of ASTM Standards, Part 7: Nonferrous Metals and AZloys; Electrodeposited Metaliic Coatings; Metal Powders, Surgical Implarits, American Society for Testing and Materials, Philadelphia, 1972.

${ }^{5}$ P. L. Rittenhouse, Initial Assessment of the Status of HTGR MetalZic Structural Materials Technology, ORNL-TM-4760 (December 1974). 
Use of Hastelloy $\mathrm{X}$ in the gas-cooled reactor systems mentioned above will require additional information and data on its mechanical behavior, thermal stability, and compatibility with helium and process environments. Our current work on Hastelloy $\mathrm{X}$ is specifically directed toward its use in the steam-cycle HTGR and includes efforts on:

1. creep and creep-rupture,

2. low-cycle fatigue and creep-fatigue interaction,

3. subcritical crack growth rates,

4. thermal stability,

5. helium corrosion and its effects on the items above.

In the sections which follow we summarize information currently available relative to each of the items above and describe the work now in progress.

\section{MATERIAL CHARACTERIZATION}

The mechanical behavior of two product forms (plate and bar) is being evaluated in this program. Specific details concerning these materials are given in Table 1. Photomicrographs of samples from both heats are given in Fig. 1. Second-phase microconstituents are probably carbides of the $\mathrm{M}_{6} \mathrm{C}$ type.

Table 1. Material Characterization

\begin{tabular}{|c|c|c|}
\hline Product form: & 13-mm (1/2-in.) plate & $\begin{array}{l}\text { 31. } 8 \text {-mm-diam (1 1/4-in.) } \\
\text { bar }\end{array}$ \\
\hline Heat No. & $2600-34936$ & $2600-3-2792$ \\
\hline Source & Cabot-Stellite & Cabot-Stellite \\
\hline ASME Specification & ASME SB-435 (N06002) & ASME SB-572 (N06002) \\
\hline Heat treatment & $\begin{array}{l}\text { Solution annealed at } 1177^{\circ} \mathrm{C} \\
\left(2150^{\circ} \mathrm{F}\right) \text { followed by a } \\
\text { rapid cool }\end{array}$ & $\begin{array}{l}\text { Solution annealed at } 1177^{\circ} \mathrm{C} \\
\left(2150^{\circ} \mathrm{F}\right) \text { followed by a } \\
\text { rapid cool }\end{array}$ \\
\hline Grain size & $78 \mu \mathrm{m}$ (ASTM 4) & 55 นผ (A3Tก 5) \\
\hline Hardness & DPH 190 & DPH 197 \\
\hline \multirow{2}{*}{ Element } & \multicolumn{2}{|c|}{ Chemical Composition, wt \% } \\
\hline & (plate) & (bar) \\
\hline $\mathrm{Ni}$ & Bal & Ba1 \\
\hline $\mathrm{Cr}$ & 21.82 & 21.25 \\
\hline $\mathrm{Fe}$ & 19.09 & 18.96 \\
\hline Mo & 9.42 & 8.99 \\
\hline Co & 1.68 & 1.94 \\
\hline w & 0.63 & 0.56 \\
\hline Mn & 0.58 & 0.57 \\
\hline Si & 0.44 & 0.41 \\
\hline c & 0.07 & 0.10 \\
\hline $\mathbf{P}$ & 0.016 & 0.018 \\
\hline $\mathbf{s}$ & $<0.005$ & $<0.005$ \\
\hline B & $<0.002$ & $<0,002$ \\
\hline
\end{tabular}



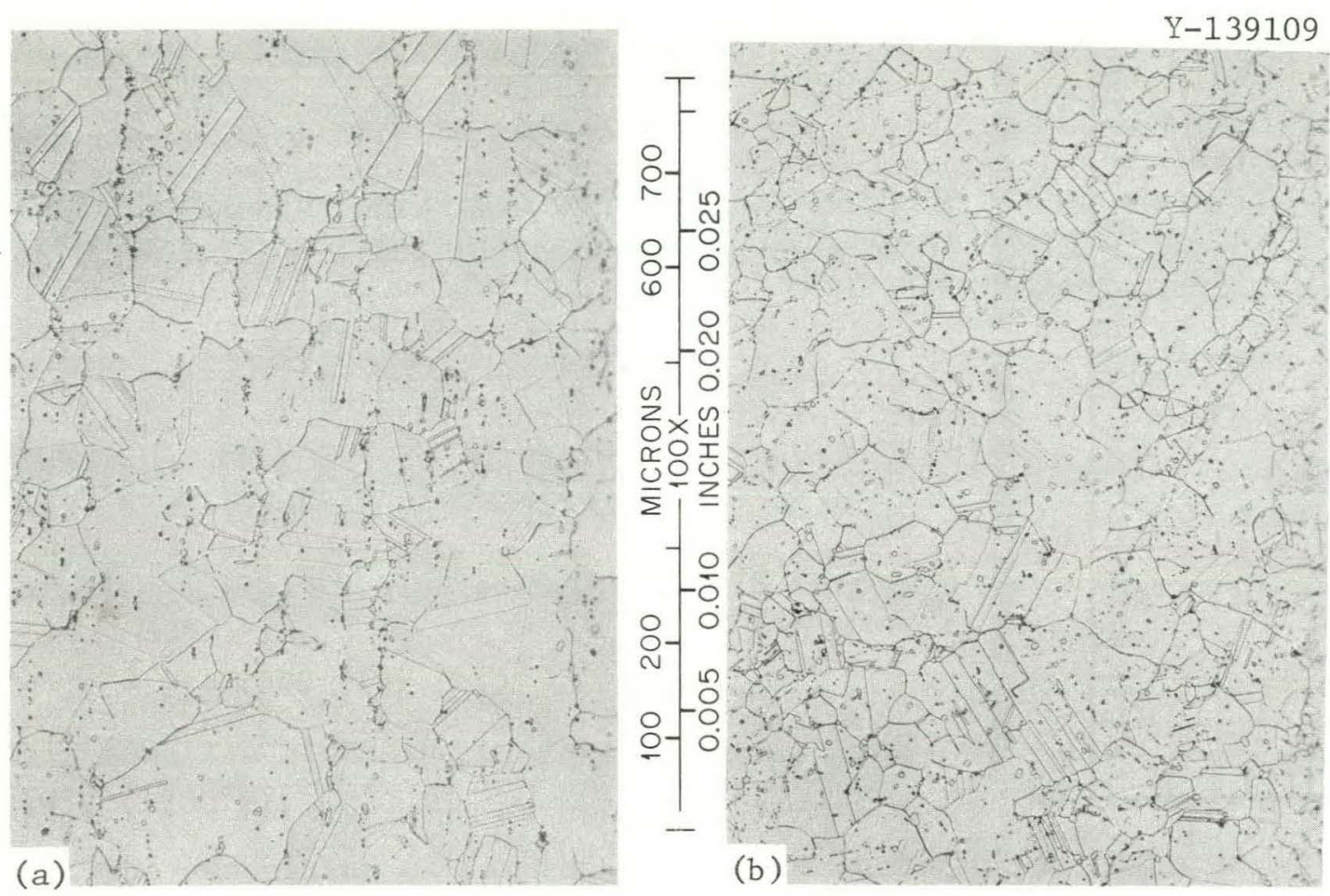

Fig. 1. Photomicrographs of Hastelloy X. (a) Heat No. 2600-3-4936, P1ate. (b) Heat No. 2600-3-2792, Bar.

Tensile tests were conducted on heat 2600-3-4936. These tests were accomplished using specimens with a 6.35-mm-diam (0.25-in.) and 31.8-mm (1,25-in.) gage length. Tensile properties generated over the temperature range 20 to $870^{\circ} \mathrm{C}\left(70\right.$ to $1600^{\circ} \mathrm{F}$ ) are given in l'able 2 , and are compared in Fig. 2 with tensile properties of other heats and product forms of Hastelloy $X$ as given in the literature. ${ }^{6-9}$ Figure 2 indicates that Hastelloy $\mathrm{X}$ shows a minimum in ductility as measured by reduction in area over the temperature range of about 500 to $750^{\circ} \mathrm{C}\left(932\right.$ to $\left.1382^{\circ} \mathrm{F}\right)$. Such a ductility minimum is typical in nickel-base high-temperature alloys. ${ }^{10}$

${ }^{6}$ HasteZZoy AZZoy X, Technical Brochure, Cabot, Stellite Division, 1974.

${ }^{7}$ A. E. Carden and T. B. Slade, High-Temperature Low-Cycle Fatigue Experiments on Hastelloy X, Am. Soc. Test. Mater. Spec. Tech. Publ. 459, American Society for Testing and Materials, Philadelphia, 1968.

${ }^{8} \mathrm{E}$. L. Wagoner, Physical Metallurgy and Mechanical Properties of HasteZloy AZZoy X, Haynes Stellite Company, Division of Union Carbide Corporation, Kokomo, Indiana, 1961.

${ }^{9} \mathrm{C}$. E. Jaske and T. L. Porfilio, Low-Cycle. Fatigue of Type 347 Stainless Steel and Hastelloy X in Hydrogen Gas Environment, TID/SNA 2047, 1971.

${ }^{10}$ M. A. Arkoosh and N. F. Fiore, "Elevated Temperature Ductility Minimum in Hastelloy Alloy X," Metall. Trans. 3: 2235-2240 (August 1972). 
Table 2. Tensile Properties of Hastelloy X Heat 2600-3-4936

\begin{tabular}{|c|c|c|c|c|c|c|c|c|c|}
\hline \multirow{3}{*}{$\begin{array}{l}\text { Test } \\
\text { No. }\end{array}$} & \multirow{2}{*}{\multicolumn{2}{|c|}{ Temperature }} & \multicolumn{4}{|c|}{ Tensile strength } & \multirow{2}{*}{\multicolumn{2}{|c|}{$\begin{array}{c}\text { Elongation in } \\
31.8 \mathrm{~mm}(1.25 \mathrm{in.}), \% \\
\end{array}$}} & \multirow{3}{*}{$\begin{array}{l}\text { Reduction in } \\
\quad \text { area }(\%)\end{array}$} \\
\hline & & & \multicolumn{2}{|c|}{$0.2 \%$ Yield } & \multicolumn{2}{|c|}{ Ultimate } & & & \\
\hline & 101 & & $(\mathrm{MPa})$ & $(k s i)$ & $(\mathrm{MPa})$ & (ksi) & Total & Uniform & \\
\hline 14892 & 20 & 70 & 359 & 52.0 & 762 & 110.5 & 50.5 & 43.8 & 59.8 \\
\hline 14893 & 20 & 70 & 349 & 50.6 & 764 & 110.8 & 51.5 & 43.9 & 59.2 \\
\hline 14894 & 20 & 70 & 350 & 50.8 & 764 & 110.8 & 51.9 & $44 \cdot 3$ & 61.4 \\
\hline 14895 & 150 & 300 & 290 & 42.1 & 682 & 98.9 & 51.1 & 44.7 & 60.6 \\
\hline $14899^{a}$ & 150 & 300 & 288 & 41.8 & 671 & 97.3 & 51.5 & 45.9 & 59.8 \\
\hline 14896 & 290 & 550 & 248 & 36.0 & 662 & 96.0 & 52.8 & 46.2 & 57.9 \\
\hline 14897 & 290 & 550 & 244 & 35.4 & 651 & 94.4 & 53.7 & 48.3 & 55.9 \\
\hline 14814 & 290 & 550 & 245 & 35.5 & 656 & 95.2 & 54.4 & 49.9 & 55.4 \\
\hline 14812 & 430 & 800 & 223 & 32.4 & 627 & 91.0 & 56.5 & 51.1 & 56.9 \\
\hline 14813 & 430 & 800 & 234 & 34.0 & 629 & 91.2 & 49.8 & 47.3 & \\
\hline 14809 & 480 & 900 & 193 & 28.0 & 623 & 90.4 & 59.0 & 53.6 & 43.6 \\
\hline 14810 & 480 & 900 & 234 & 34.0 & 622 & 90.2 & 55.9 & 53.0 & 38.4 \\
\hline 14811 & 480 & 900 & 219 & 31.8 & 621 & 90.1 & 58.4 & 53.6 & 48.2 \\
\hline 14807 & 540 & 1000 & 239 & 34.6 & 592 & 85.8 & 49.9 & 46.5 & 40.9 \\
\hline 14808 & 540 & 1000 & 221 & 32.1 & 596 & 86.5 & 48.8 & 43.9 & 31.4 \\
\hline 14804 & 595 & 1100 & 220 & 31.9 & 585 & 84.9 & 53.3 & 47.9 & 40.9 \\
\hline 14805 & 595 & 1100 & 223 & 32.4 & 587 & 85.1 & 53.1 & 47.7 & 41.9 \\
\hline 14806 & 595 & 1100 & 232 & 33.7 & 581 & 84.3 & 51.5 & 47.0 & 43.0 \\
\hline 14802 & 650 & 1200 & 214 & 31.1 & 507 & 73.6 & 39.7 & 39.4 & 35.9 \\
\hline 14803 & 650 & 1200 & 213 & 30.9 & 507 & 73.6 & 39.7 & 37.9 & 39.4 \\
\hline $14799^{a}$ & 705 & 1300 & 223 & 32.4 & 425 & 61.6 & 48.5 & 23.0 & 41.7 \\
\hline 14800 & 705 & 1300 & 215 & 31.2 & 452 & 65.5 & 37.3 & 29.9 & 33.6 \\
\hline 14801 & 705 & 1300 & 212 & 30.8 & 460 & 66.7 & 37.6 & 30.8 & 35.9 \\
\hline $14790^{a}$ & 760 & 1400 & 215 & 31.2 & 320 & 46.4 & 73.3 & 6.4 & 66.1 \\
\hline $14791^{A}$ & 760 & 1400 & 219 & 31.5 & 323 & 46.9 & 75.6 & 7.8 & 68.8 \\
\hline 14796 & 760 & 1400 & 217 & 31.5 & 385 & 55.8 & 66.6 & 11.7 & 55.8 \\
\hline 14798 & 760 & 1400 & 206 & 29.9 & 381 & 55.2 & 68.1 & 12.0 & 57.0 \\
\hline $14792^{a}$ & 815 & 1500 & 221 & 32.1 & 241. & 34.9 & 87.2 & 3.0 & 78.9 \\
\hline $14793^{a}$ & .815 & 1500 & 232 & 33.7 & 240 & 34.8 & 72.2 & 3.4 & 74.3 \\
\hline $14794^{a}$ & 815 & 1500 & 231 & 33.5 & 238 & 34.5 & 74.6 & 3.2 & 77.1 \\
\hline $14795^{d}$ & 815 & 1500 & 213 & 30.9 & 241 & 34.9 & 81.2 & 3.2 & 81.4 \\
\hline 14797 & 815 & 1500 & 225 & 32.7 & 288 & 41.7 & 86.0 & 5.8 & 69.6 \\
\hline $14815^{a}$ & 870 & 1600 & 161 & 23.4 & 165 & 24.0 & 79.8 & 2.1 & 88.9 \\
\hline $14898^{a}$ & 870 & 1600 & 163 & 23.6 & 168 & 24.3 & 84.4 & 2.3 & 88.2 \\
\hline
\end{tabular}

${ }^{a}$ Constant strain rate of $0.4 \% / m i n$ through failure. All other tests at this rate through yielding and then increased by factor of 4 . 
ORNL-DWG 76-10427
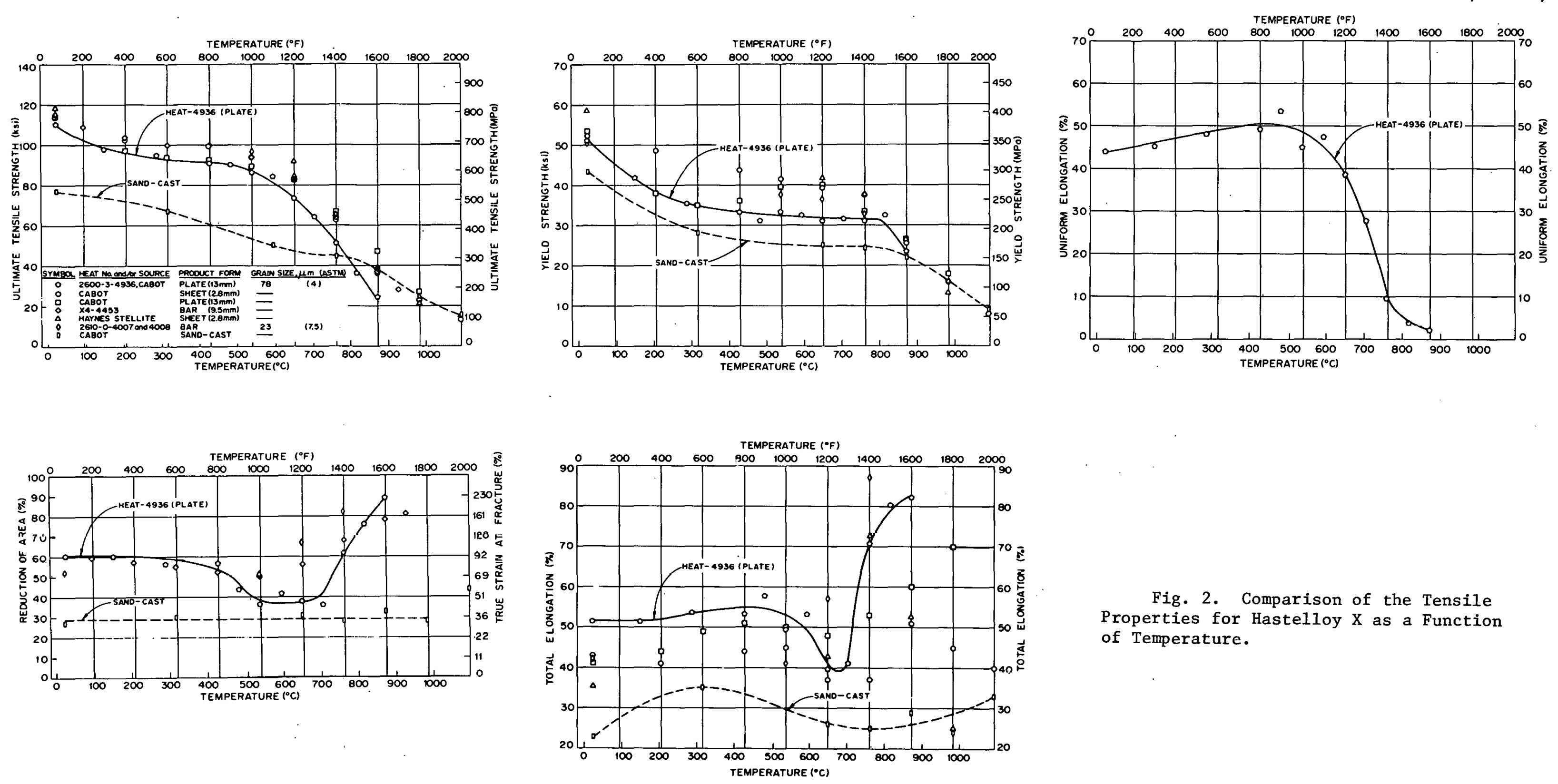

Fig. 2. Comparison of the Tensile Properties for Hastelloy $\mathrm{X}$ as a Function of Temperature. 
ENVIRONMENTAL TEST FACILITIES

It is well established that the fatigue and creep-rupture properties of engineering alloys can be affected by operation at elevated temperatures in gaseous media.11-15 For engineering purposes the magnitude of the effect may be large or small, depending upon the nature of the surface film formed, the surface-to-volume ratio of the components, and the type of loading involved, that is, static or dynamic. The extent of reaction can be particularly pronounced if the environment acts as a mass transfer agent for oxidation, decarburization, or carburization. These reactions can be particularly deleterious if intergranular attack occurs, since grain boundaries tend to be weak at elevated temperatures. In air environments the primary oxide to form on Hastelloy $X$ is a smooth adherent scale of $\mathrm{Cr}_{2} \mathrm{O}_{3}$ which remains stable and protective unt11 temperatures of about $982^{\circ} \mathrm{C}\left(1800^{\circ} \mathrm{F}\right)$ are exceeded. ${ }^{16}$ This adherent oxide makes Hastelloy $\mathrm{X}$ an excellent material for elevated-temperature applications in air. Above about $982^{\circ} \mathrm{C}\left(1800^{\circ} \mathrm{F}\right)$ a volatile oxide product, $\mathrm{CrO}_{3}$, forms which is nonprotective. ${ }^{16}$

The primary coolant of the HTGR, on the other hand, is helium, and it contains only small quantities of oxidizing species, as indicated in Table 3. Therefore the nature (i.e., adherent or exfoliating) of surface films or corrosion products that may develop as a consequence of prolonged exposure $(280,000 \mathrm{hr})$ to environments given in Table 3 needs to be determined. Since current ASME elevated-temperature design allowables are based on mechanical properties such as tensile, creep, and fatigue

${ }^{11} \mathrm{H}$. E. McCoy, "Type 304 Stainless Steel vs Flowing $\mathrm{CO}_{2}$ at Atmospheric Pressure and 1100-1800 F," Corrosion 81 84-94 (1965).

${ }^{12} \mathrm{C}$. P. Sullivan and M. J. Donachie, Jr:, "Microstructure and Mechanical Properties of Iron-Base (-Containing) Superalloys," Met. Eng. Q. 11(4): $1 \rightarrow$ (November 1971).

${ }^{13}$ F. S. Pettit and J. K. Tien, "Hut Gas Environment - Alloy Reactions and Their Relation to Fatigue," Corrosion Fatigue: Chemistry, Mechanics and Microstructure, National Association of Corrosion Engineers, NACE-2, 1972, pp. 576-89.

${ }^{14} \mathrm{G}$. W. Titus and W. L. Clarke, Jr., "Compatibility of Reactor Materials with High-Temperature Gases," Nucl. Eng. Des. 24: 125-44 (1973).

${ }^{15}$ D. S. Wood, M. Farrow, A. B. Baldwin, and W. T. Burke, "Creep Rupture Properties of Some High Temperature Reactor Circuit Materials in Helium," pp. 158.1-158.9 in Int. Conf. Creep and Fatigue in Elevated Temperature Applications, Inst. Mech. Eng. Conf. Publ. 13, Institution of Mechanical Engineers, London, 1973.

$16 \mathrm{~J}$. S. Brunhouse and G. W. Titus, Evaluation of Long-Term Gas Corrosion of Heat Resistant Alloys for Use as Gas-Cooled Reactor Fuel Cladding, USAEC Research and Development Report IDO-28605 (1963). 
that were generated in air, the impact of HTGR prototypic environments on these properties must be defined for design purposes. Toward this end, facilities for determining creep, subcritical crack growth, and strain-controlled fatigue behavior in HTGR prototypic environments were or are currently being developed and will be discussed in the following sections.

Table 3. Estimated Impurity Levels in Gas-Cooled Reactor Helium

\begin{tabular}{|c|c|c|c|}
\hline \multirow{2}{*}{ Impurity } & \multicolumn{3}{|c|}{ Impurity levels, fatm } \\
\hline & Minimum $^{a}$ & Expected $b$ & European ${ }^{c}$ \\
\hline $\mathrm{H}_{2} \mathrm{O}$ & $<1$ & 50 & $\mathrm{~d}$ \\
\hline $\mathrm{CH}_{4}$ & 20 & 50 & $20-50$ \\
\hline $\mathrm{CO}$ & 10 & 450 & $2-50$ \\
\hline $\mathrm{CO}_{2}$ & $<1$ & $<2$ & \\
\hline $\mathrm{H}_{2}$ & 200 & 1500 & $100-500$ \\
\hline $\mathrm{O}_{2}$ & $10^{-19}$ & $10^{-16}$ & $\ll 10^{-3}$ \\
\hline $\mathrm{N}_{2}$ & $<1$ & $<1$ & $<10$ \\
\hline \multicolumn{4}{|c|}{$\begin{array}{l}a_{\text {General Atomic Company estimate for totally leak- }} \\
\text { steam generator at equilibrium after startup. } \\
b_{\text {Estimate based on General Atomic Company technical }} \\
\text { ification limits. }\end{array}$} \\
\hline
\end{tabular}

Creep Test Facilities

Conventional high-precision creep testing (i.e., in air) involves, in brief, load train systems for applying uniaxial loads with a minimum of bending stresses, extensometry to monitor the strain which accrues with time, and furnaces and controls for maintaining the desired test temperature within narrow limits for long periods of time. Testing in a controlled environment adds substantially to the above in complexity, effort, and cost. The ten systems we are now using for environmental tests required extensive development related to the design of the specimen, load train, extensometry, environmental chamber, and, particularly, to the methods for supplying and monitoring the helium environments. Six frames were also built for testing of control specimens in air. 
Loading of the creep specimens is provided conventionally through calibrated lever arms. The load train itself is designed to minimize bending loads by the use of universal joints and the elimination of threaded connections. This practice is carried over to the specimens (see Fig. 3) by attaching them to the load train with tapered fittings clamped over each end. The environmental chamber (Fig. 4) is constructed of austenitic stainless steel pipe (enclosed in the furnace bore) with water-cooled flanges and metal bellows at each end. The bellows are provided to further facilitate alignment of the load train. U-cup seals, lightly lubricated to minimize friction, are used where the polished pull rods enter and exit the environmental chamber. This allows a positive environmental seal and, yet, permits application of load and unrestricted specimen extension. Seals are also used where the extensometer rods are led through the bottom of the chamber. The bores of the environmental chambers are seasoned (preoxidized) prior to use.

Three Chromel-Alumel thermocouples are attached equidistantly along the specimen gage length to monitor temperature. The three-zone furnace surrounding the environmental chamber bore is shunted to achieve a maximum of $2^{\circ} \mathrm{C}\left(3.6^{\circ} \mathrm{F}\right)$ difference over the 25.4-mm (1-in.) gage length. The control thermocouple is placed in the annulus between the chamber and the furnace to avoid any possibility of reaction between the thermocouple materials and the helium environment that would lead to possible changes in thermocouple output. Before any test specimen is brought to temperature and loaded, the environmental chamber is evacuated and then backfilled with helium.

Provision of a system for supplying, monitoring, and controlling the simulated HTGR primary-coolant helium environment has been the most difficult step in facility preparation. The three types of systems considered are (1) premixed (tank) gas supply, (2) once-through dynamicmix supply, and (3) recirculating-loop dynamic-mix supply. The first (premixed) can be provided at the lowest cost and is the most versatile system; however, it does not offer continuous on-line control of purity levels. Early conccrns relative to gas stability (i.e., possible changes in impurity levels in the tanks during storage and use) and cleanliness were, and continue to be, dispelled by our experience in the use of this method. Prior to adopting this method of supply, tanks containing controlled additions of $\mathrm{H}_{2}+\mathrm{CO}+\mathrm{CH}_{4}$ to helium were prepared and bled from 1000 psia to 50 psia over a $600-\mathrm{hr}$ period. (A normal period for tank use in test is $<300 \mathrm{hr}$ ). No changes in impurity levels were detected during thic pcriod. A schemarlc of the premixed system is shown in Fig. 5 .

Once-through dynamic-mix systems can provide simulated HTGR primarycoolant helium by continuous additions of $\mathrm{H}_{2}$, etc. (through micrometering valves), to high-purity helium. Such systems are intermediate in cost and versatility. Construction of such a system is in progress and is shown schematically with the premixed system in Fig. 6. We have also considered dynamic-mix recirculating loops whtch are attractive from 
ORNL-DWG 75-14128

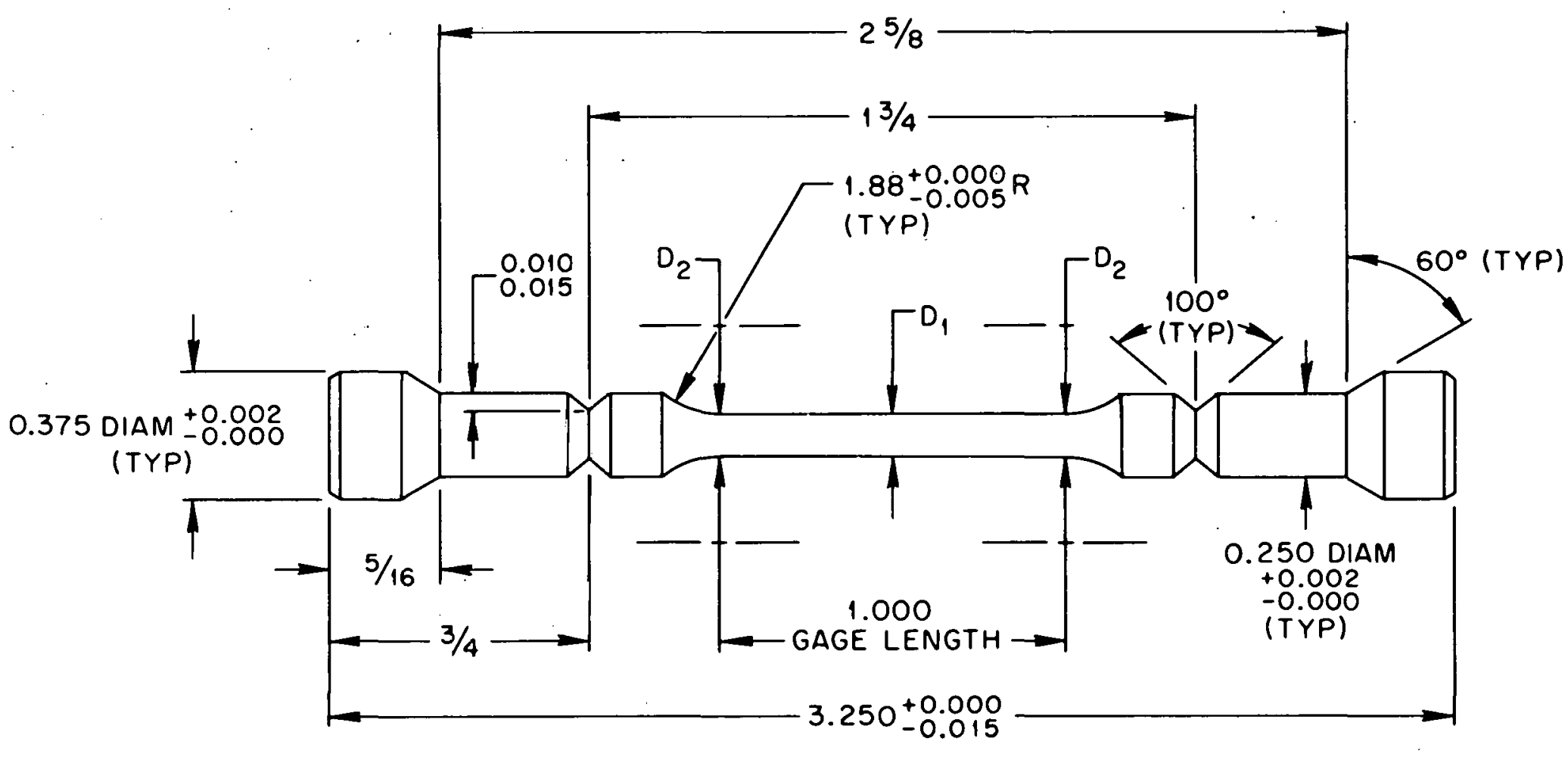

NOTE: ALL DIMENSIONS IN INCHES

$$
\begin{aligned}
& D_{1}= 0.125 \pm 0.001 \text { DIAM } \\
& D_{2}= \text { FROM O.0010 TO } 0.0015 \\
& \text { GREATER THAN } D_{1}
\end{aligned}
$$

Fig. 3. Environmental Creep Test Specimen. 1 in. $=25.4 \mathrm{~mm}$. 


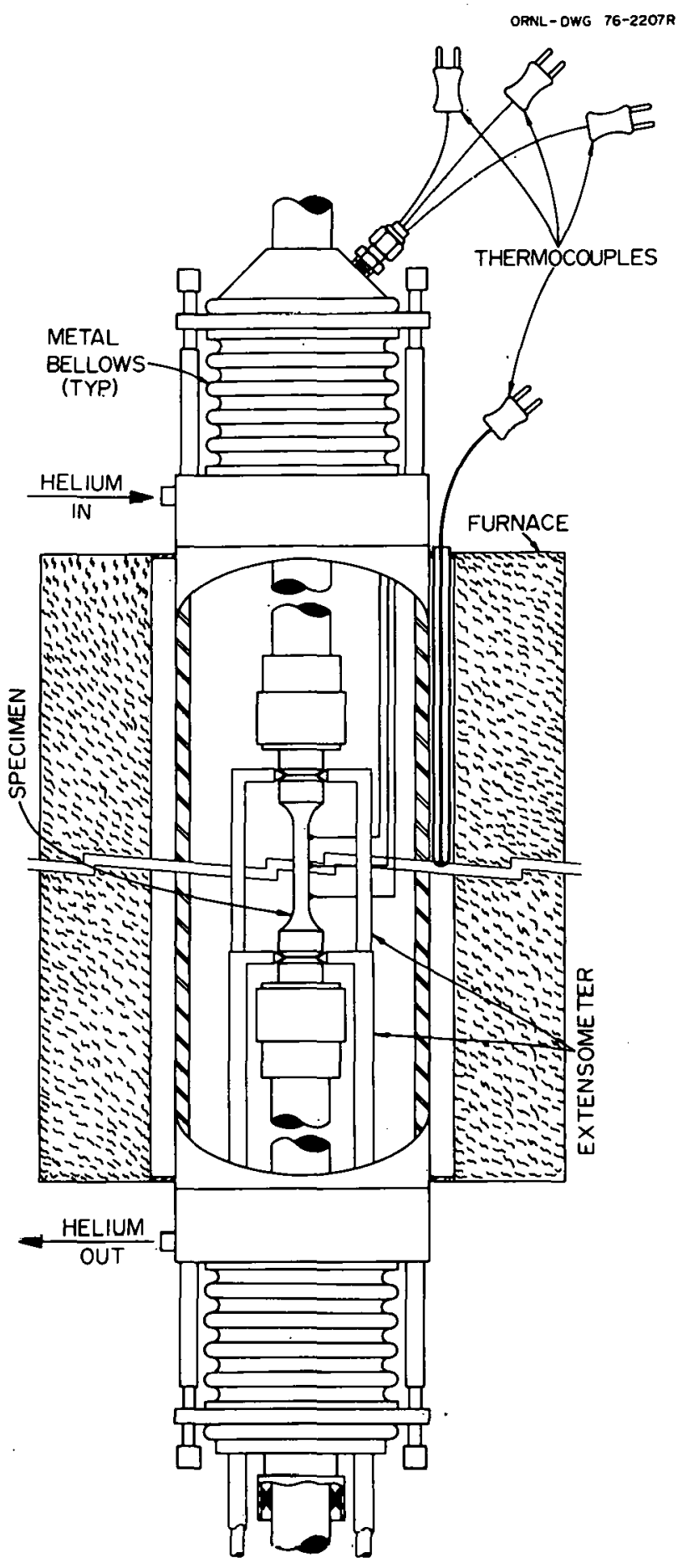

Fig, 4. Creep Environmental Test Chamber. 
ORNL-DWG 76-2206R 10 ENVIROMENTAL

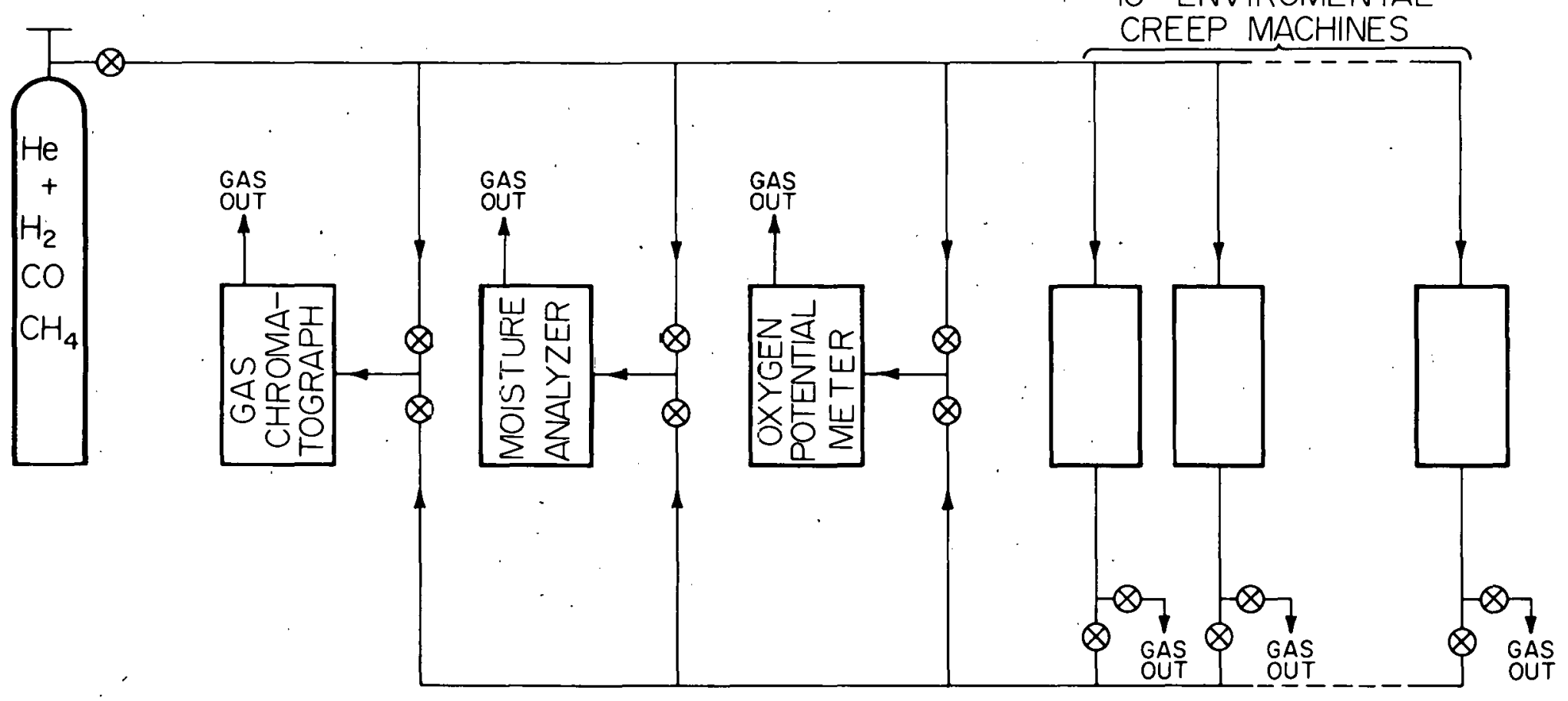

Fig. 5. Schemati= of the Premixed Gas Supply System. 
ORNL-DWG 75-141KR

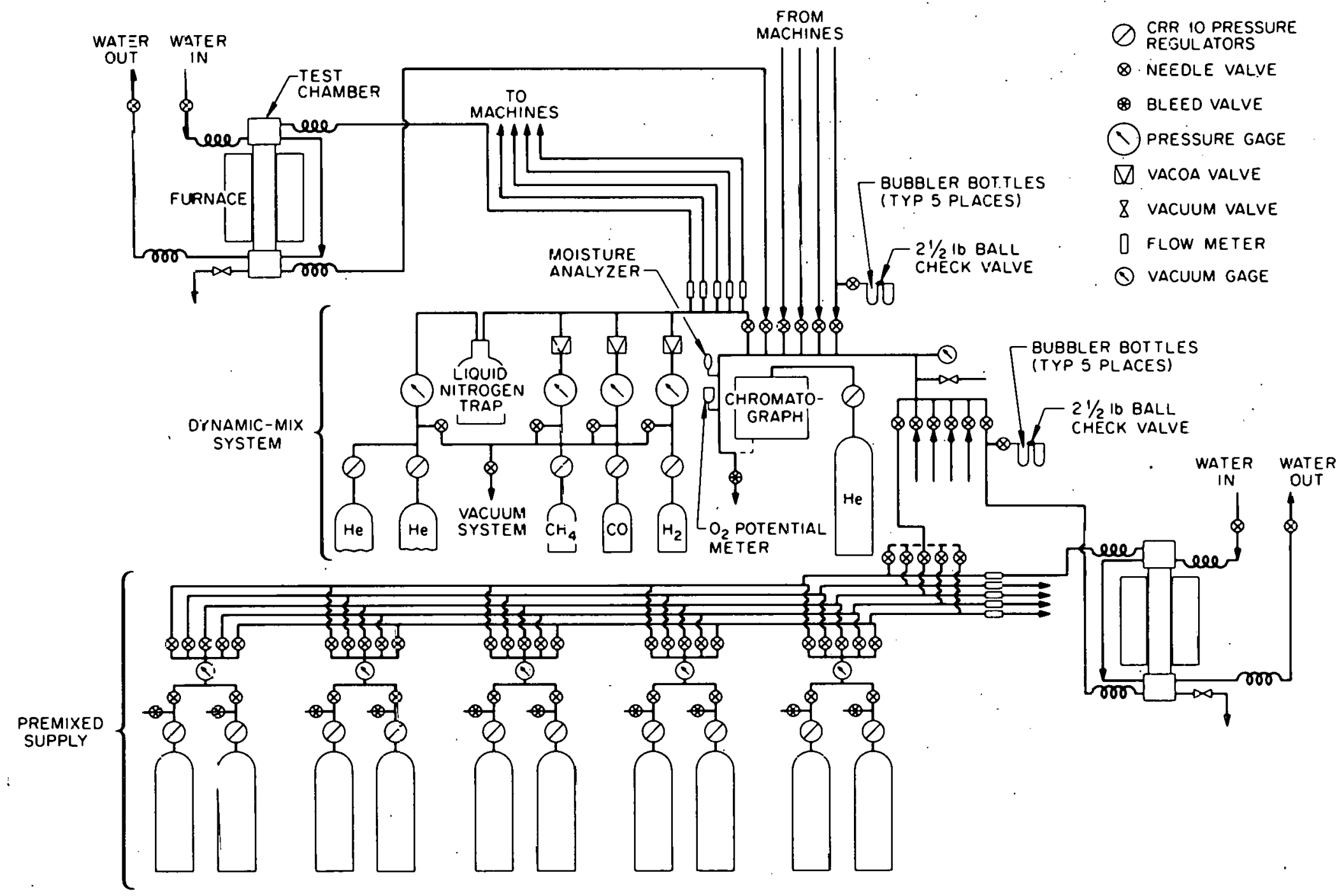

Fig. 6. Schematic of the Dynamic and Premixed Gas Supply System. 
the standpoint of helium costs and long-term stability of the helium environment. These systems are, however, of minimum versatility, and their construction costs far exceed those which could be considered in our program.

The impurity levels in the helium supply are monitored entering and leaving the environmental creep chambers. The $\mathrm{H}_{2}, \mathrm{CO}$, and $\mathrm{CH}_{4}$ levels are measured using a gas chromatograph. The chromatograph offers an additional leak-check feature by indicating $\mathrm{N}_{2}$ level. Water vapor content of the gas is followed with a separate moisture analyzer, and a solid-state oxygen potential meter is used as the oxygen partial pressure reference.

Until now the environment for all tests has been supplied from premixed tanks containing controlled additions of $\mathrm{H}_{2}, \mathrm{CO}$, and $\mathrm{CH}_{4}$. System pressure is normally 1.1 to $1.2 \mathrm{~atm}$, and the gas flow through the chambers ranges from 30 to $50 \mathrm{~cm}^{3} / \mathrm{min}$.

Impurity levels in the simulated HTGR primary-coolant helium before entering and after leaving the environmental chambers are typified by the values given in Table 4. Differences between the inflowing and effluent gas concentrations are due to metal-gas reactions occurring within the system. Comparison of the gas impurity levels given in Table 4 with the estimated impurity levels expected in steam-cycle gas-cooled reactors (Table 3 ) indicates that the test environments are appropriate.

Table 4. Impurity Levels in the Simulated HTGR Primary-Coolant Helium Before Entering and After Leaving the Creep Machines.

\begin{tabular}{|c|c|c|}
\hline Impurity & $\begin{array}{c}\text { Entering } \\
\text { content }(\mu \mathrm{atm})^{a}\end{array}$ & $\begin{array}{c}\text { Leaving } \\
\text { content }(\mu a t m)^{a}\end{array}$ \\
\hline $\mathrm{H}_{2}$ & $250-300$ & $230-290$ \\
\hline $\mathrm{CH}_{4}$ & $25-30$ & $20-30$ \\
\hline $\mathrm{CO}$ & $15-25$ & $10-15$ \\
\hline $\mathrm{H}_{2} \mathrm{O}$. & $2-7$ & $10-25$ \\
\hline $\mathrm{O}_{2}$ & $<10^{-15}$ & $<10^{-15}$ \\
\hline
\end{tabular}

Fatigue Test Facility

A schematic diagram of the vacuum and environmental fatigue test chamber under construction is shown in Fig. 7. Upon completion this chamber will be connected to the gas analysis and supply system discussed previously. Therefore, no tests have been conducted to date in helium 


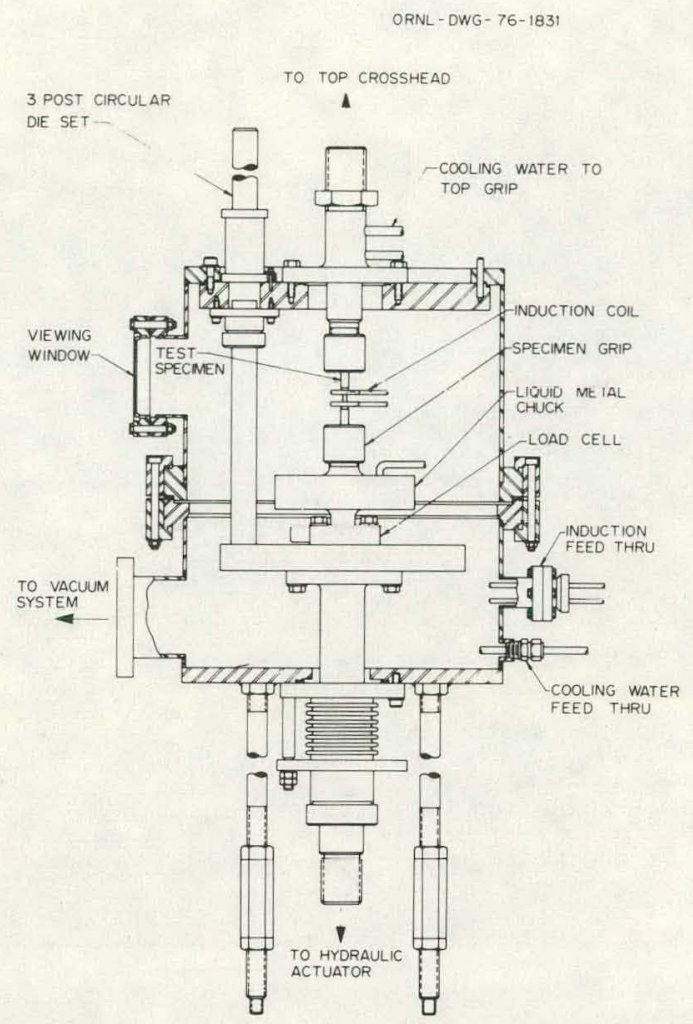
Chamber.

Fig. 7. Schematic of Vacuum and Environmental Fatigue Test

with controlled impurity levels; however, considerable baseline data generated in air at elevated temperatures have been obtained.

Fully reversed axial push-pull testing is accomplished in closedloop electrohydraulic fatigue test machines (Fig. 8). Axial strain control is maintained by employing a diametral extensometer and a simple diametral-to-axial strain computer. Total strain range, $\Delta \varepsilon_{t}$, was thus determined by the relation

$$
\Delta \varepsilon_{t}=(\Delta \sigma / E)(1-2 \nu)+2 \Delta \varepsilon_{d},
$$

where $E$ is Young's modulus, $\nu$ is Poisson's ratio, $\Delta \varepsilon_{d}$ is the diametral strain range, and $\Delta \sigma$ is the peak-to-peak stress range from the hysteresis loops.

A schematic drawing of a fatigue specimen is shown in Fig. 9. Specimens were heated by induction in air, with thermocouples attached to the specimens some distance from the point of minimum diameter. Tests were conducted at several temperatures ranging from room temperature to $871^{\circ} \mathrm{C}\left(1600^{\circ} \mathrm{F}\right)$. 

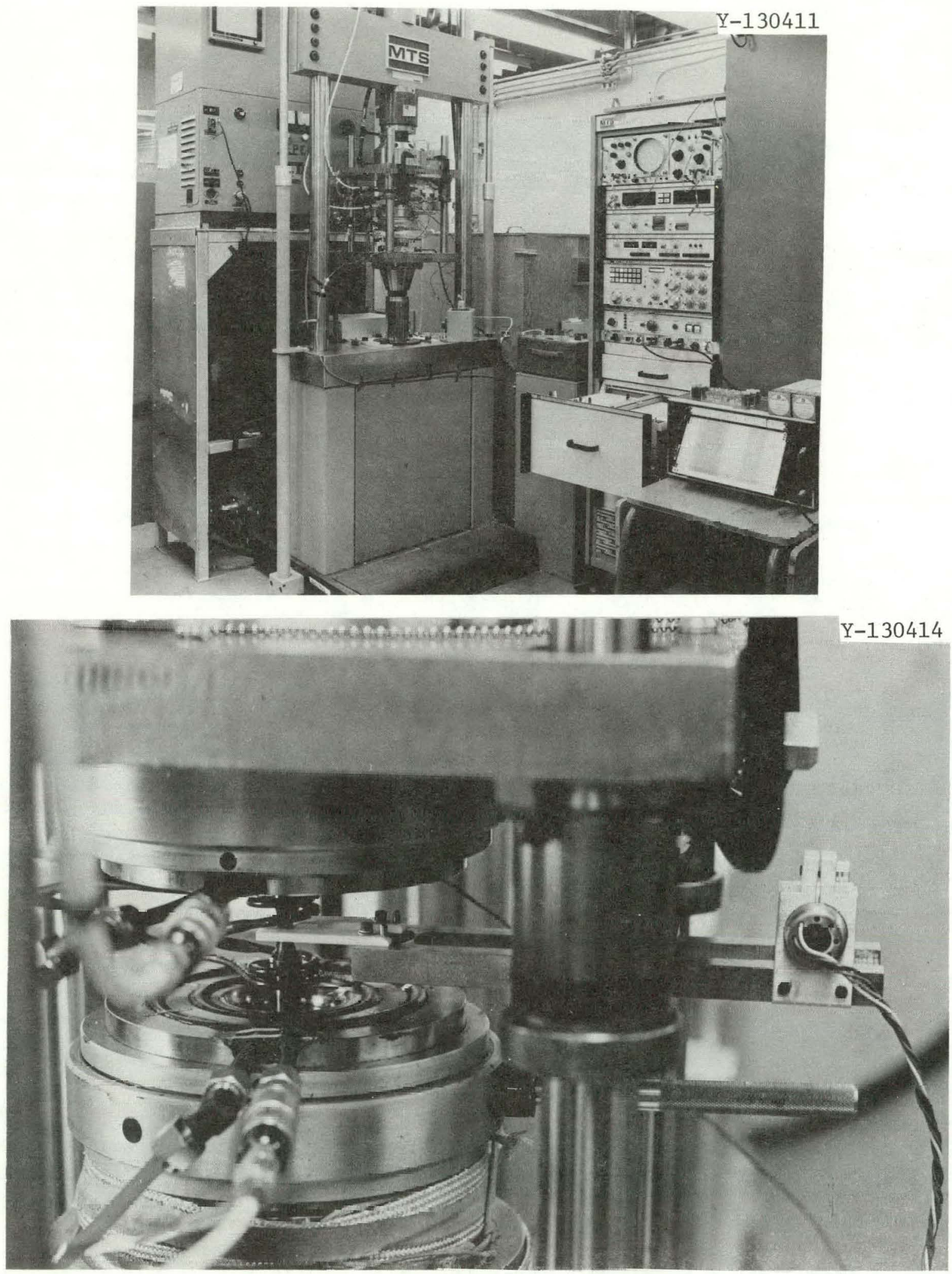

Fig. 8. Typical Strain-Controlled Fatigue System Used at ORNL for Elevated-Temperature Fatigue Testing. 


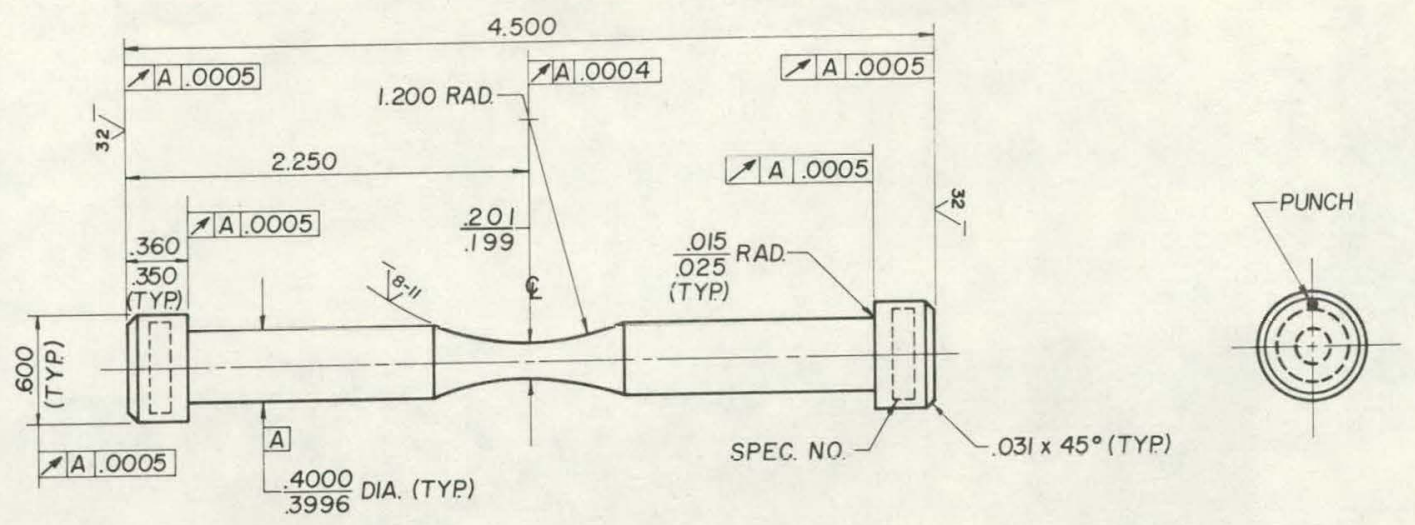

Fig. 9. Fabrication Drawing Showing Details of Fully Reversed Strain- or Load-Controlled Fatigue Specimen. All dimensions are in inches ( 1 in. $=25.4 \mathrm{~mm}$ ).

\section{Subcritical Crack Growth Test Facility}

Subcritical crack growth tests were conducted both in air and in an environmental chamber shown in Fig. 10. The gas supply and analysis system is essentially the premixed type shown in Fig. 5, and helium gas impurity levels are comparable to those given in Table 4.

Two specimen geometries were employed for subcritical crack growth testing: the compact tension specimen $(h / w=0.60)$ and the wedge opening load (WOL) specimen $(h / w=0.48)$ (see Fig. 11). The small compact tension specimen was chosen since it could be conveniently tested in an existing vacuum furnace, while the WOL specimen was selected as the reference specimen for most of the crack growth studies in air, since its longer length permits a lower rate of change of stress intensity factor with crack length, and more data can be collected from a given test. The stress intensity expression used for the WOL specimen was as follows:

$$
\begin{aligned}
\Delta K= & (\Delta P \sqrt{a} / B w)\left[30.96-195.8(a / w)+730.6(a / w)^{2}\right. \\
& \left.-1186.3(a / w)^{3}+754.6(a / w)^{4}\right],
\end{aligned}
$$

where

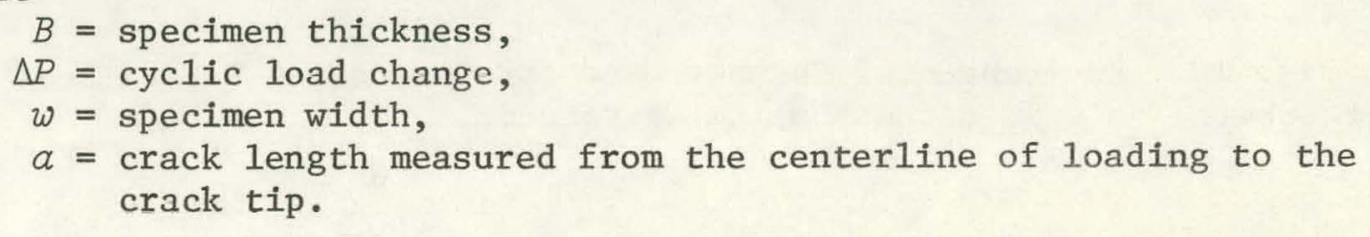




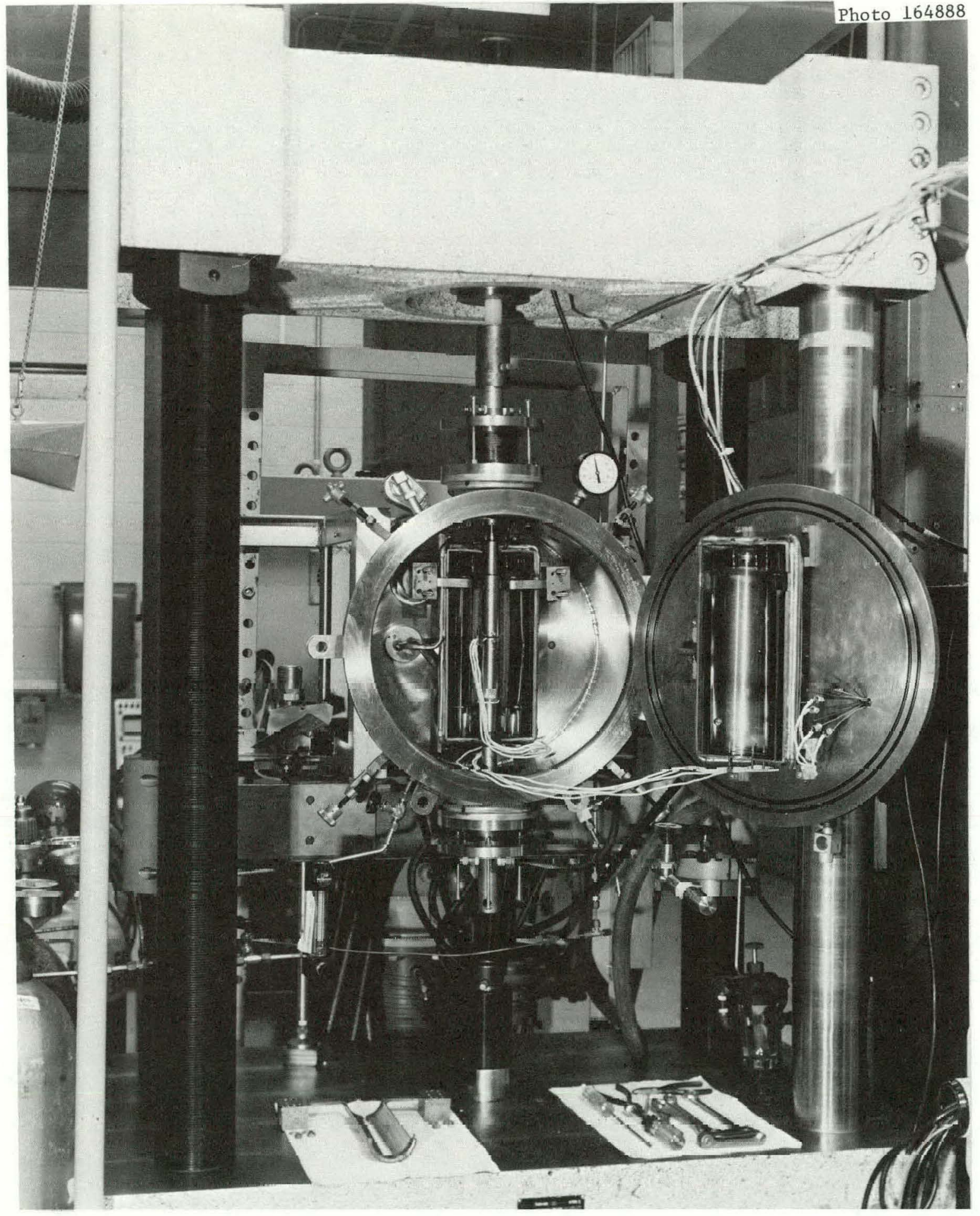

Fig. 10. Environmental Chamber Used for Conducting Subcritical Crack Growth Tests in Either Helium or Vacuum. 

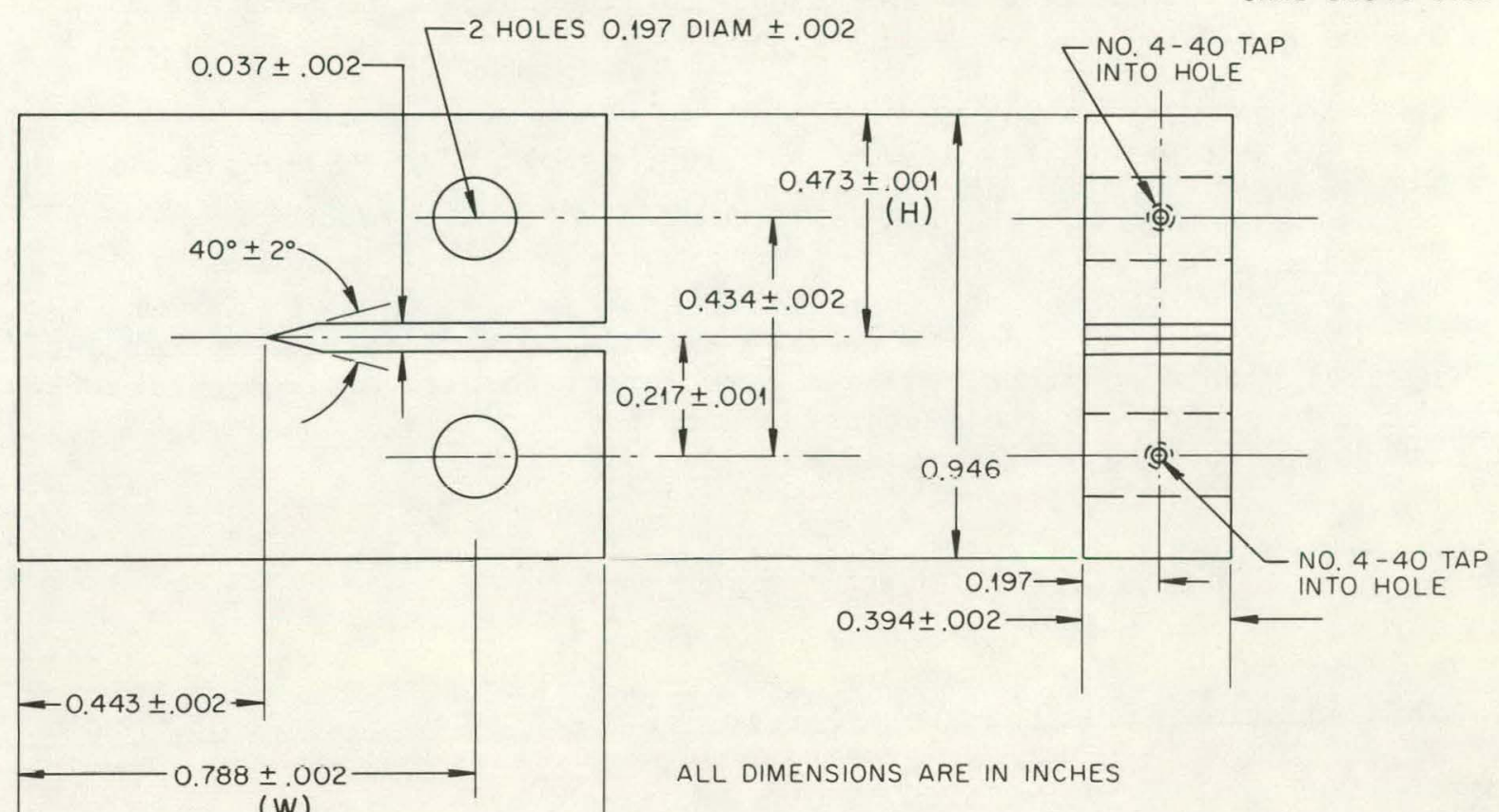

(a)

(a)

0.985

(a)

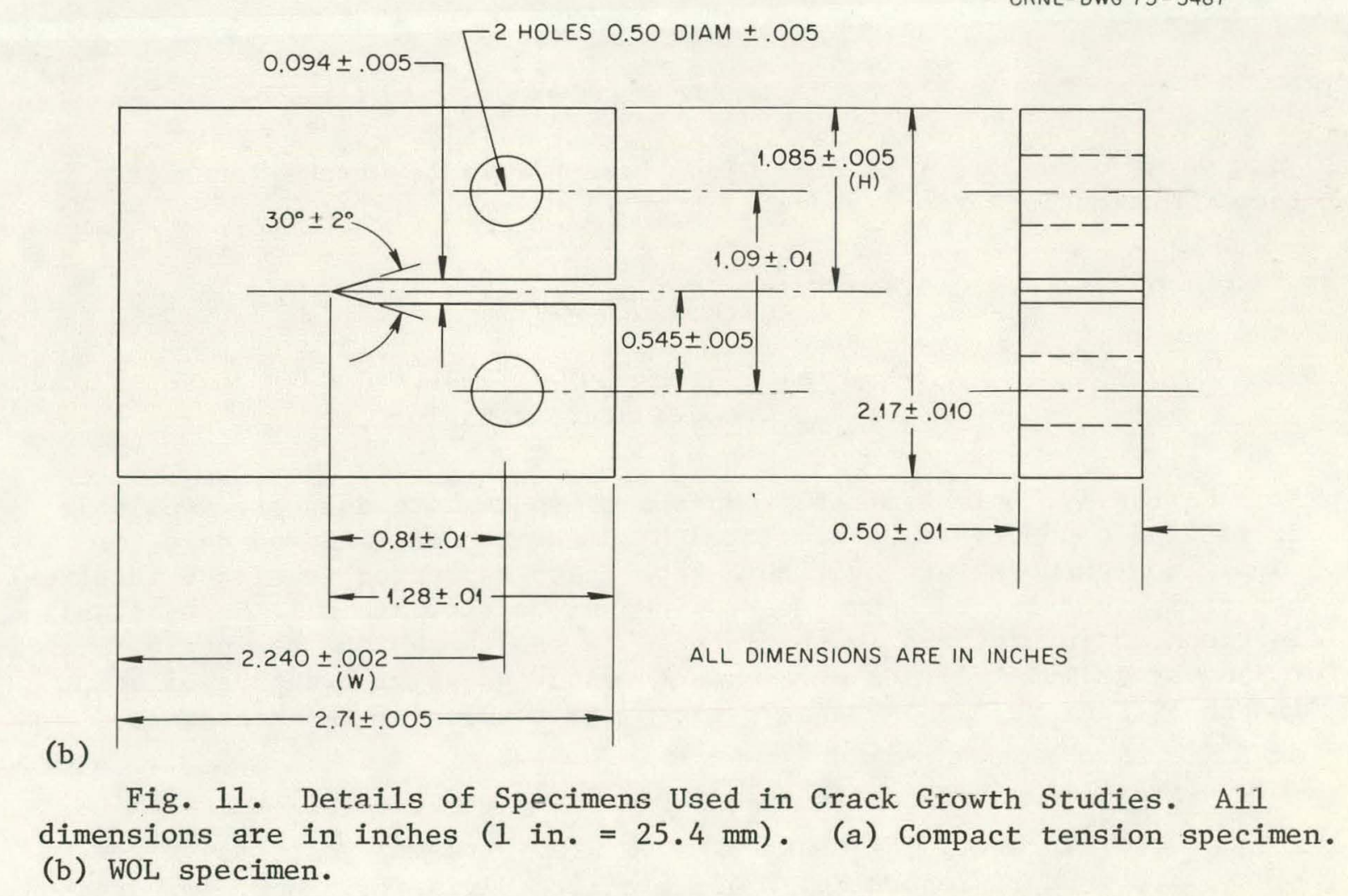


The stress intensity expression used for the compact tension specimen was as follows:

$$
\begin{aligned}
\Delta K= & (\Delta P / B \sqrt{w})\left[29.6(\alpha / w)^{0.5}-185.5(a / w)^{1 \cdot 5}+655.7(a / w)^{2 \cdot 5}\right. \\
& \left.-1017(a / w)^{3 \cdot 5}+638.9(a / w)^{4 \cdot 5}\right] .
\end{aligned}
$$

We calculated $d a / d N$ vs $\Delta K$ from recorded $a$ vs $N$ data ( $N=$ number of cycles) with a computer, using a first-order forward divided difference technique. For any two successive data points $\left(a_{i}, N_{i}\right)$ and $\left(a_{i+1}, N_{i+1}\right)$, crack growth rate was computed by

$$
\frac{d a}{d N}=\frac{a_{i+1}-a_{i}}{N_{i+1}-N_{i}} .
$$

This equation gives the average value of $d a / d N$ between cycles $N_{i}$ and $N_{i+1}$.

The associated $\Delta K$ for the same cycle increment is computed by use of the simple arithmetic mean of the crack length during that increment:

$$
a_{\text {av }}=\left(a_{i}+a_{i+1}\right) / 2
$$

This value of $a_{\text {av }}$ is then used with the appropriate stress intensity factor expressions given above.

\section{RESULTS}

\section{Creep and Creep-Rupture Behavior}

Currently, only limited creep and creep-rupture data are available from tests conducted in a simulated HTGR environment, and no data for comparison purposes are available from tests conducted in air on identical material, that is, the same heat. Comparison air data will be available in the near future, and in the interim it was thought to be instructive to compare simulated HTGR environment rupture data with data available in the literature. ${ }^{17-19}$ Table 5 gives the results of tests conducted

${ }^{17}$ Hastelloy AZZoy X, Technical Brochure, Cabot, Stellite Division, 1974.

${ }^{18} \mathrm{~J}$. W. Tackett, The Creep Rupture Properties of Hastelloy Alloy X Sheet, Tech. Dept. Report No. 8745, Stellite Division, Cabot, Corporation, Kokomo, Indiana, 1975.

${ }^{19}$ Component and Systems Development Progrom Q. Prog. Rep. Dec. 31, 1975, General Atomic Project 3218, GA-A13778 
Table 5. Interim Results of ORNL Creep-Rupture Tests on Hastelloy $\mathrm{X}$ in Progress or Completed.

\begin{tabular}{|c|c|c|c|c|c|c|c|c|c|c|}
\hline \multirow{2}{*}{$\begin{array}{c}\text { Test } \\
\text { No. }\end{array}$} & \multirow{2}{*}{$\begin{array}{l}\text { Heat } \\
\text { No. }\end{array}$} & \multicolumn{2}{|c|}{ Temperature } & \multicolumn{2}{|c|}{ Stress } & \multirow{2}{*}{$\begin{array}{l}\text { Rupture } \\
\text { Life } \\
\text { (hr) }\end{array}$} & \multirow{2}{*}{$\begin{array}{c}\text { Elongation } \\
(\%)\end{array}$} & \multirow{2}{*}{$\begin{array}{c}\text { Steady-State } \\
\text { Creep Rate } \\
\left(\mathrm{hr}^{-1}\right)\end{array}$} & \multirow{2}{*}{ Environment } & \multirow{2}{*}{$\begin{array}{l}\text { Time-to- } \\
\text { Tertiary } \\
\text { Creep } \\
\text { (hr) }\end{array}$} \\
\hline & & $\left({ }^{\circ} \mathrm{C}\right)$ & $\left({ }^{\circ} \mathrm{F}\right)$ & $(\mathrm{MPa})$ & (ksi) & & & & & \\
\hline 15772 & $2600-3-4936$ & 649 & 1200 & 172 & 25 & 6466 & 34.9 & $1.66 \times 10^{-5}$ & $\mathrm{He}$ & 3950 \\
\hline 16267 & $2600-3-4936$ & 649 & 1200 & 172 & 25 & In progress & In progress & & Air & \\
\hline 17329 & $2600-3-4936$ & 649 & 1200 & 138 & 20 & In progress & In progress & & $\mathrm{He}$ & \\
\hline 15771 & $2600-3-4936$ & 704 & 1300 & 172 & 25 & 1007 & 35.4 & $1.37 \times 10^{-4}$ & $\mathrm{He}$ & 550 \\
\hline 15058 & $2600-3-4936$ & 704 & $130 \mathrm{C}$ & 138 & 20 & 4045 & 21.4 & $1.72 \times 10^{-5}$ & $\mathrm{He}$ & 2010 \\
\hline 15792 & $2600-3-4936$ & 704 & $130 \mathrm{C}$ & 138 & 20 & 4588 & 23.0 & $1.08 \times 10^{-5}$ & $\mathrm{He}$ & 1830 \\
\hline 16268 & $2600-3-4936$ & 704 & 1300 & 138 & 20 & In progress & In progress & & Air & \\
\hline 17328 & $2600-3-4936$ & 704 & 1300 & 103 & 15 & In progress & In progress & & $\mathrm{He}$ & \\
\hline $1 \in 031$ & $2600-3-2792$ & 760 & 1400 & 152 & 22 & 159.3 & 57.5 & $1.24 \times 10^{-3}$ & $\mathrm{He}$ & 55 \\
\hline 17330 & $2600-3-4936$ & 760 & 1400 & 138 & 20 & In progress & In progress & & Air & \\
\hline 16490 & $2600-3-4936$ & 760 & 1400 & 103 & 15 & 2690 & 18.7 & $1.16 \times 10^{-5}$ & $\mathrm{He}$ & 1480 \\
\hline 17332 & $2600-3-4936$ & 816 & 1500 & 69 & 10 & In progress & In progress & & $\mathrm{He}$ & \\
\hline 16269 & $2600-3-4936$ & 816 & 1500 & 69 & 10 & In progress & In progress & & Air & \\
\hline 16054 & $2600-3-2792$ & 871 & 1600 & 62 & 9 & 554 & 34.8 & $9.25 \times 10^{-5}$ & $\mathrm{He}$ & 205 \\
\hline 16126 & $2600-3-4936$ & 871 & 1600 & 34 & 5 & In progress & In progress & & $\mathrm{He}$ & \\
\hline
\end{tabular}


to date or in progress at ORNL in a simulated HTGR helium environment. Table 6 outlines stress-rupture tests planned to be conducted during 1976. Data from five different stress-temperature test conditions generated in air by workers at Cabot-Stellite ${ }^{18}$ and data generated in a simulated HTGR environment by workers at General Atomic Co. ${ }^{19}$ as we11 as our own data are given in Table 7. In Fig. 12 all of the stress-rupture data are plotted for comparison purposes. Considering the wide variations known to exist in isothermal stress-rupture data due to subtle differences in heat-to-heat chemistry and variations in product form processing histories, no conclusions can be made regarding the influence of HTGR simulated environments on the stress-rupture properties of Hastelloy $\mathrm{X}$. However, if there are differences they do not appear to be large, at least over the short term. Figure 13 gives the complete creep curves for five ORNL creep tests conducted in helium. Additional data will soon be available from tests in progress.

Table 6. Stress-Rupture Tests to be Conducted on Hastelloy X during 1976.

\begin{tabular}{|c|c|c|c|c|c|c|}
\hline \multirow{3}{*}{$\begin{array}{l}\text { Heat } \\
\text { Number }\end{array}$} & \multicolumn{3}{|c|}{$649^{\circ} \mathrm{C} \quad\left(1200^{\circ} \mathrm{F}\right)$} & \multicolumn{3}{|c|}{$704^{\circ} \mathrm{C} \quad\left(1300^{\circ} \mathrm{F}\right)$} \\
\hline & \multicolumn{2}{|c|}{ Stress } & \multirow{2}{*}{ Environment } & \multicolumn{2}{|c|}{ Stress } & \multirow{2}{*}{ Environment } \\
\hline & $(\mathrm{MPa})$ & (ksi) & & (MPa) & (ksi) & \\
\hline $2600-3-4936$ & 207 & 30 & $\mathrm{He}$ & 103 & 15 & Air \\
\hline $2600-3-2792$ & 207 & 30 & $\mathrm{He}$ & & & \\
\hline
\end{tabular}

\section{Fatigue and Creep-Fatigue Interaction}

Fully reversed isothermal uniaxial strain-controlled fatigue tests have been completed on a single heat and product form (heat 2600-3-4936, plate) of Hastelloy $X$ over the temperature range from 24 to $871^{\circ} \mathrm{C}\left(75\right.$ to $\left.1600^{\circ} \mathrm{F}\right)$. Plots of total strain range, $\Delta \varepsilon_{t}$, plastic strain range, $\Delta \varepsilon_{p}$, and elastic strain range, $\Delta \varepsilon_{e}$, vs cycles to failure are given for room temperature, $538^{\circ} \mathrm{C}\left(1000^{\circ} \mathrm{F}\right), 649^{\circ} \mathrm{C}\left(1200^{\circ} \mathrm{F}\right), 760^{\circ} \mathrm{C}$ $\left(1400^{\circ} \mathrm{F}\right)$, and $871^{\circ} \mathrm{C}\left(1600^{\circ} \mathrm{F}\right)$ in Figs. 14 to 18 respectively. The data of Jaske and Porfilio ${ }^{20}$ were included in the plot of the $760^{\circ} \mathrm{C}\left(1400^{\circ} \mathrm{F}\right)$ data. These tests were conducted at a continuous cycling strain rate of $4 \times 10^{-3} / \mathrm{sec}$ except as noted, using a ramp wave form of the type shown in Fig. 19. Figure 19 also shows wave forms for tests in which a strain dwell or hold period was introduced in either or both the tensile

${ }^{20} \mathrm{C}$. E. Jaske and T. L. Porfilio, Low-Cycle Fatigue of Type 347 Stainless Steel and Hastelloy $X$ in Hydrogen Gas Environment, TID/SNA 2047, 1971. 
Table 7. Tabulation of Creep and Creep-Rupture Data Obtained from Several Sources and Environments for Hastelloy $\mathrm{X}$

\begin{tabular}{|c|c|c|c|c|c|c|c|c|c|c|c|c|}
\hline \multirow{2}{*}{$\begin{array}{l}\text { Tes: } \\
\text { No. }\end{array}$} & \multirow{2}{*}{$\begin{array}{l}\text { Heat } \\
\text { No. }\end{array}$} & \multicolumn{2}{|c|}{ Temperature } & \multicolumn{2}{|c|}{ Stress } & \multicolumn{2}{|c|}{$\begin{array}{c}\text { Hours for } \\
\text { Indicated } \\
\text { Creep Strain }\end{array}$} & \multirow{2}{*}{$\begin{array}{l}\text { Rupture } \\
\text { Life } \\
\text { (hr) }\end{array}$} & \multirow{2}{*}{$\begin{array}{l}\text { Elongat:on } \\
(\%)\end{array}$} & \multirow{2}{*}{$\begin{array}{c}\text { Steady-State } \\
\text { Creep Rate } \\
\left(10^{-4} \times \mathrm{hr}^{-1}\right)\end{array}$} & \multirow{2}{*}{ Environment } & \multirow{2}{*}{$\begin{array}{l}\text { Source } \\
\text { of Data }\end{array}$} \\
\hline & & $\left({ }^{\circ} \mathrm{C}\right)$ & $\left({ }^{\circ} \mathrm{F}\right)$ & (MPa) & (ksi) & $\overline{(2 \%)}$ & $\overline{(5 \%)}$ & & & & & \\
\hline $1577 ?$ & $2600-3-4936$ & 649 & 1200 & 172 & 25 & 850 & 2170 & 6466 & 34.9 & 0.17 & $\mathrm{He}$ & ORNL \\
\hline 13167 & 4248 & 649 & 1200 & 172 & 25 & 480 & 1400 & & & 0.32 & Air & Cabot \\
\hline 13703 & 4410 & 649 & 1200 & 172 & 25 & 490 & 1380 & 7704 & 68.3 & 0.28 & Air & Cabot \\
\hline 13143 & 4486 & 649 & 1200 & 172 & 25 & 640 & 1900 & & & 0.20 & Air & Cabot \\
\hline 12715 & 94210 & 649 & 1200 & 172 & 25 & 950 & 3200 & & & 0.11 & Air & Cabot \\
\hline 15053 & $2600-3-4936$ & 704 & 1300 & 138 & 20 & 340 & 1920 & 4045 & 21.4 & 0.17 & $\mathrm{He}$ & ORNL \\
\hline $1579 ?$ & $2600-3-4936$ & 704 & 1300 & 138 & 20 & 500 & 2590 & 4588 & 23.0 & 0.11 & $\mathrm{He}$ & ORNL \\
\hline \multirow[t]{3}{*}{16263} & $2600-3-4936$ & 704 & 1300 & 138 & 20 & 300 & & & & $0.10^{\mathrm{a}}$ & Air & ORNL \\
\hline & нН2798 & 760 & 1400 & 172 & 25 & 3.7 & 9.9 & 37.5 & 84 & 50 & $\mathrm{He}$ & $\mathrm{GA}^{\mathrm{b}}$ \\
\hline & нН 2798 & 760 & 1400 & 172 & 25 & 4.3 & 9.3 & 36.5 & 86 & 50 & $\mathrm{He}$ & $\mathrm{GA}^{\mathrm{b}}$ \\
\hline 13787 & 4410 & 760 & 1400 & 172 & 25 & 4.5 & 10.0 & 52.9 & 91.8 & 43 & Air & Cabot \\
\hline 12552 & 4438 & 760 & 1400 & 172 & 25 & 2.3 & 5.7 & 27.0 & 78.5 & 85 & Air & Cabot \\
\hline 12723 & 94210 & 760 & 1400 & 172 & 25 & 6.0 & 13.0 & 54.1 & 100.9 & 39 & Air & Cabot \\
\hline 16125 & $2600-3-4936$ & 760 & 1400 & 138 & 20 & 30 & 103 & 304.6 & 38.9 & 4.00 & $\mathrm{He}$ & ORNL \\
\hline 13163 & 4248 & 760 & 1400 & 138 & 20 & 14 & 36 & 149.0 & 68.9 & 14 & Air & Cabot \\
\hline 13783 & 4410 & 760 & 1400 & 138 & 20 & 18 & 48 & 513.4 & 91.5 & 10 & Air & Cabot \\
\hline 12573 & 4438 & 760 & 1400 & 138 & 20 & 8 & 20 & 110.1 & 67.2 & 25 & Air & Cabot \\
\hline 13147 & 4486 & 760 & 1400 & 138 & 20 & 9 & 33 & 182.0 & 86.8 & 13 & Air & Cabot \\
\hline \multirow[t]{3}{*}{12593} & 94210 & 760 & 1400 & 138 & 20 & 15 & 39 & & & 13 & Air & Cabot \\
\hline & HН2798 & 871 & 1600 & 69 & 10 & 22 & 67 & 201.5 & 79 & 5.0 & He & $\mathrm{GA}^{\mathrm{b}}$ \\
\hline & HН2798 & 871 & 1600 & 69 & 10 & & & 314 & 93 & 3.7 & $\mathrm{He}$ & $\mathrm{GA}^{\mathrm{b}}$ \\
\hline 13171 & 4248 & 871 & 1600 & 69 & 10 & 9.0 & 25 & 70.8 & 33.6 & 20 & Air & Cabot \\
\hline 1388: & 4410 & 871 & 1600 & 69 & 10 & 6.5 & 16 & 76.2 & 68.9 & 31 & Air & Cabot \\
\hline 12567 & 4438 & 871 & 1600 & 69 & 10 & 4.3 & 11.6 & 60.5 & 45.8 & 41 & Air & Càbot \\
\hline $1256 ;$ & 4438 & 871 & 1600 & 69 & 10 & 23.0 & 69 & 307.9 & 41.9 & 7 & Air & Cabot \\
\hline $1315 ?$ & 4486 & 871 & 1600 & 69 & 10 & 14.0 & 40 & 141.3 & 39.9 & 11 & Air & Cabot \\
\hline 12583 & 94210 & 871 & 1600 & 69 & 10 & 12.0 & 38 & 153.6 & 53.3 & 11 & Air & Cabot \\
\hline 12571 & 94210 & 871 & 1600 & 69 & 10 & 17.0 & 54 & 241.7 & 63.1 & 8 & Air & Cabot \\
\hline
\end{tabular}

${ }^{a}$ In the very first step of the steady-state creep and therefore the value is interim.

bata obtained from General Atomic Co. 


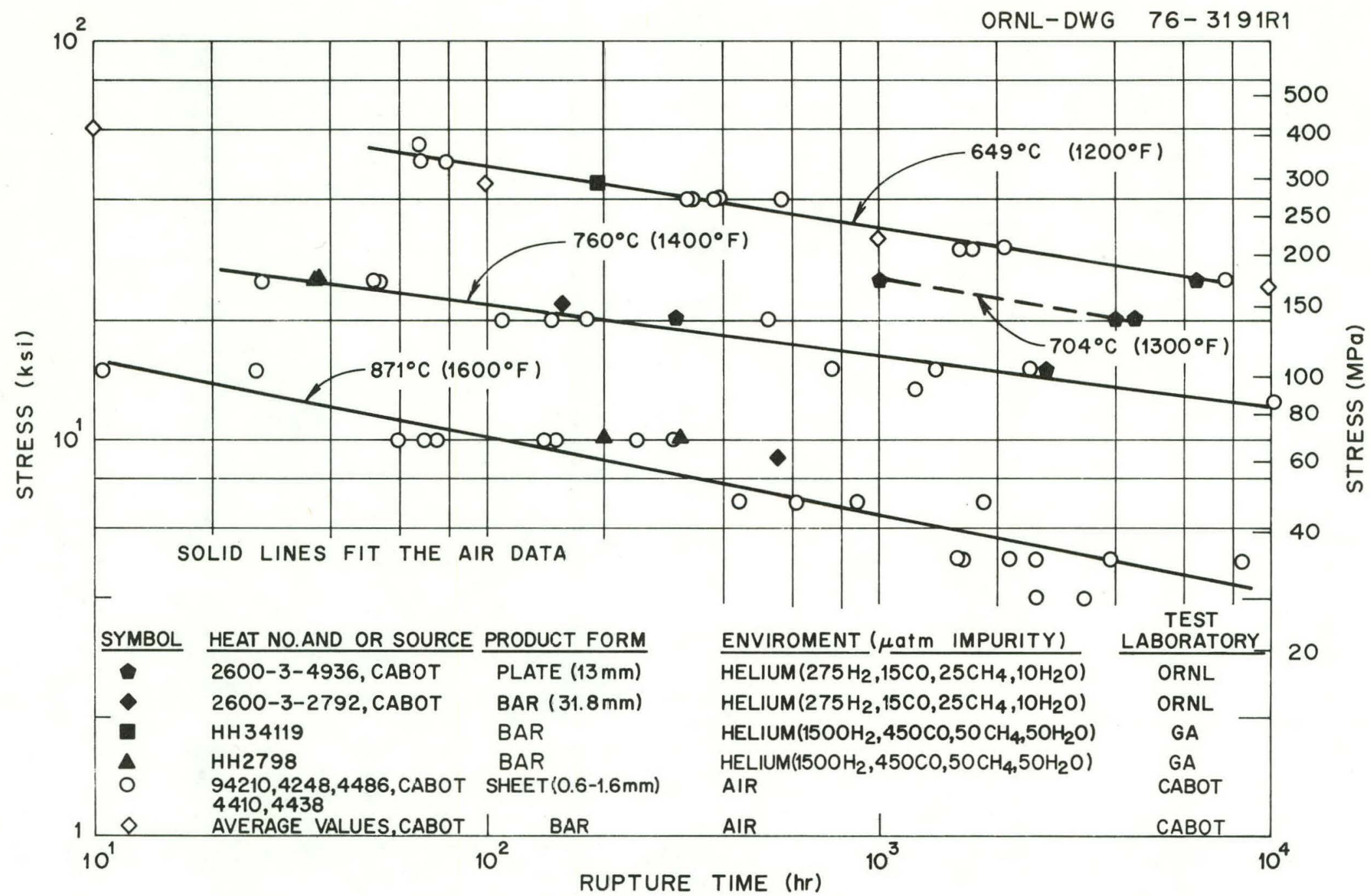

Fig. 12. Isothermal Stress-Rupture Plots for Hastelloy X Comparing Rupture Data from Tests Conducted in Helium with Controlled Impurities ( $1 \mathrm{~atm}=1.0 \times 10^{5} \mathrm{~N} / \mathrm{m}^{2}$ ) and Test Data Generated in Air as Reported From Several Sources. 

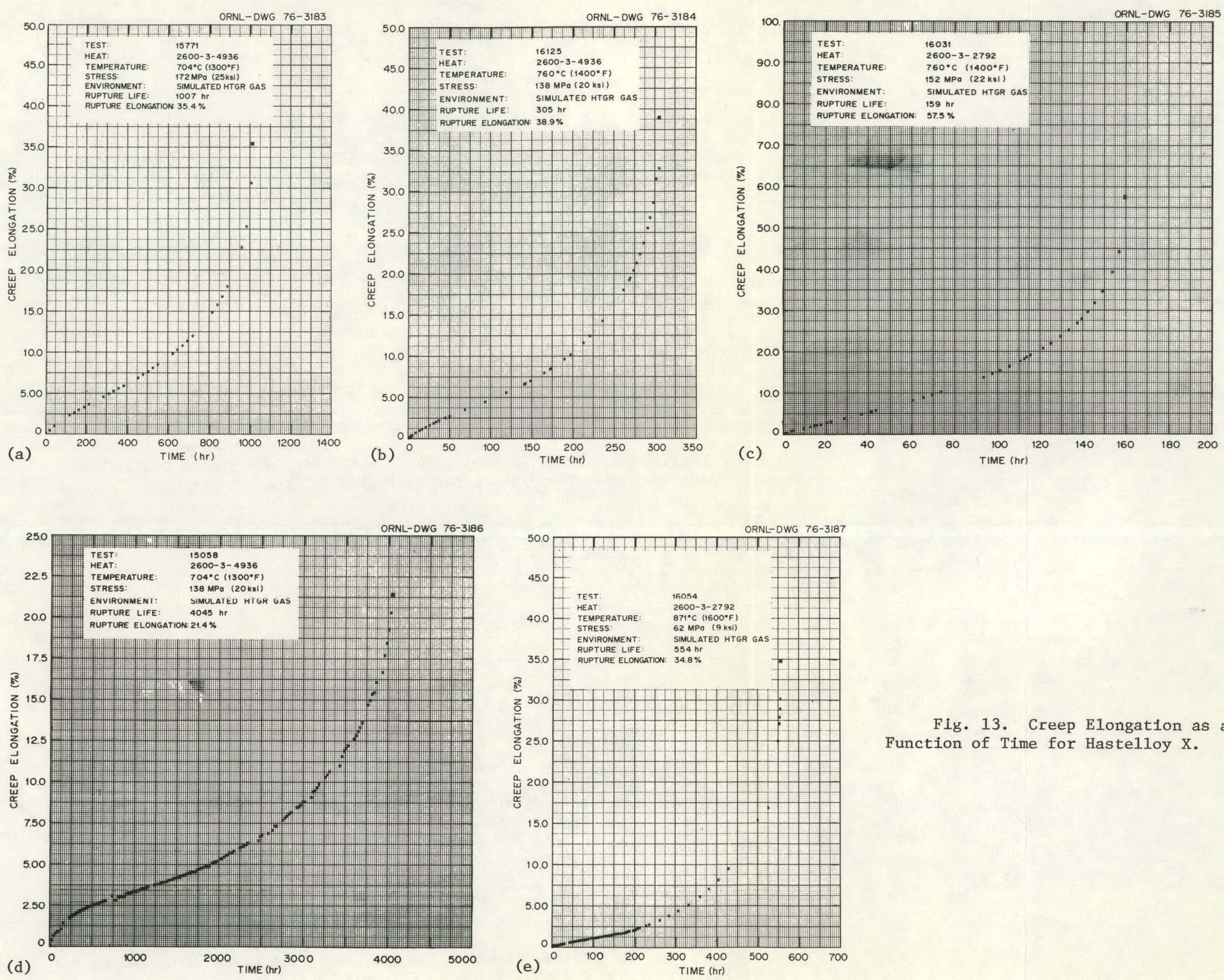

Fiy. 13. Creep Elongation as a Function of Time for Hastelloy $\mathrm{X}$. 


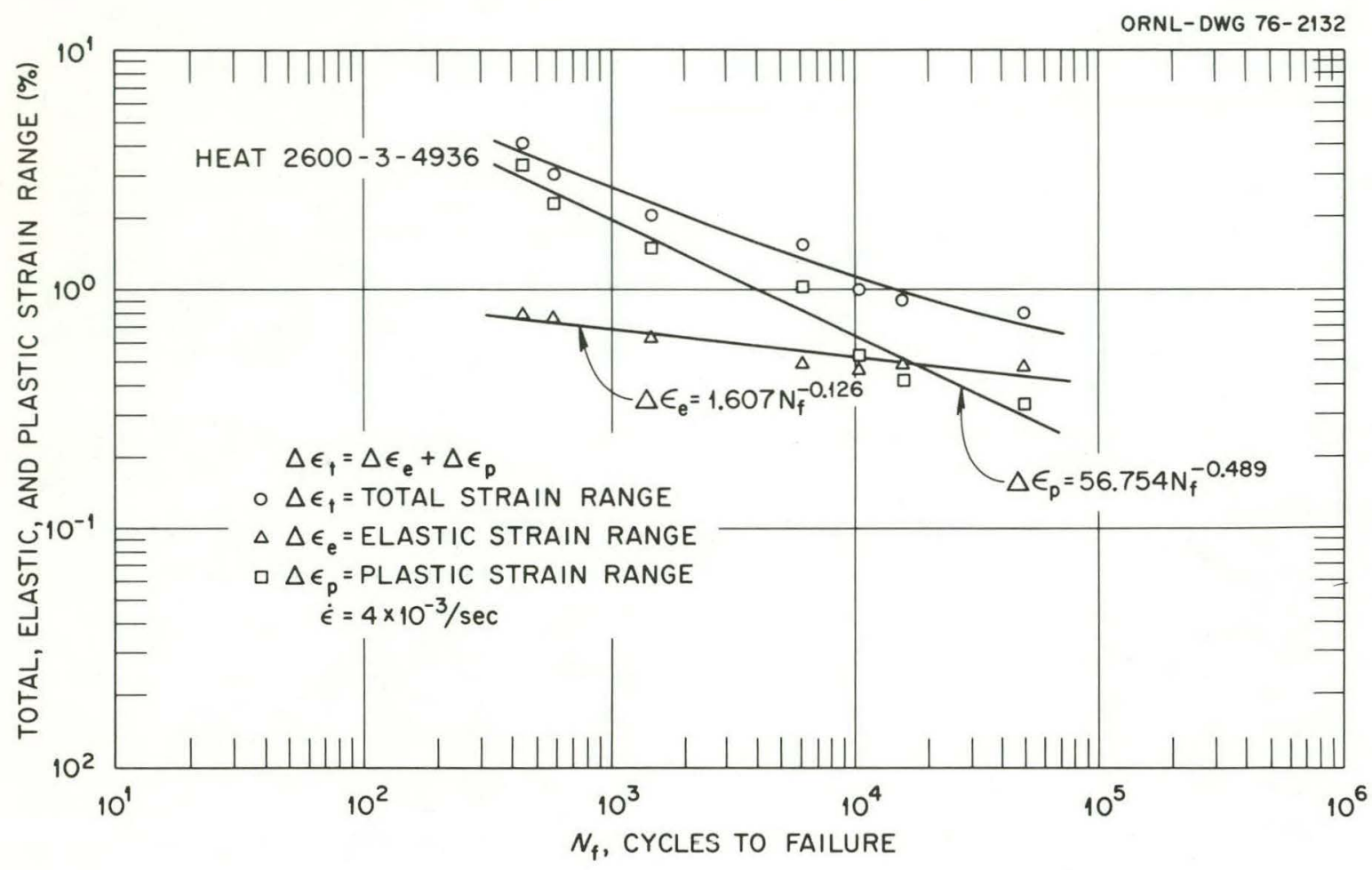

Fig. 14. Total, Elastic, and Plastic Strain Range vs Cycles to Failure at Room Temperature for Hastelloy X Tested in Air.

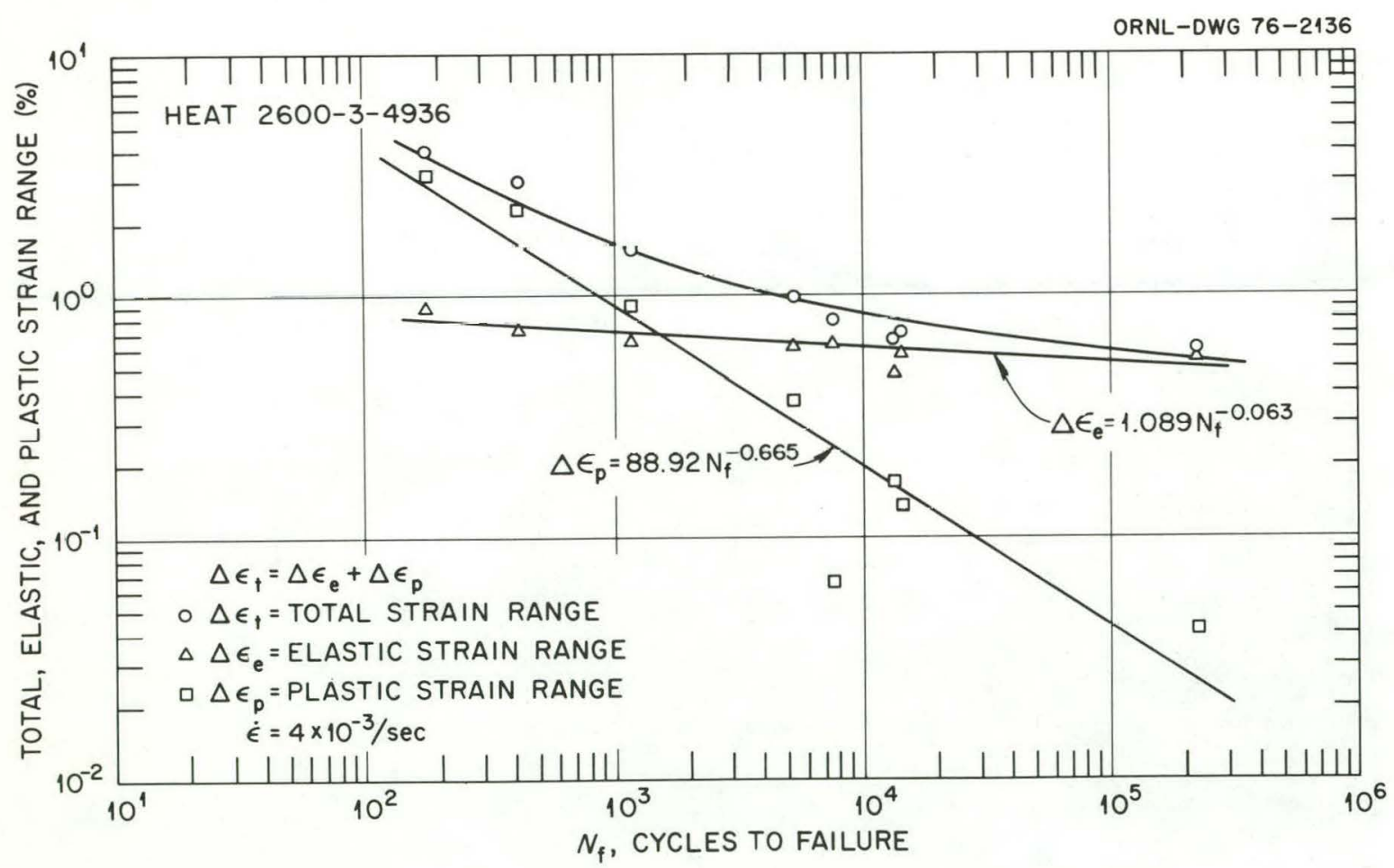

Fig. 15. Tota1, Elastic, and Plastic Strain Range vs Cycles to Failure at $538^{\circ} \mathrm{C}\left(1000^{\circ} \mathrm{F}\right)$ for Hastelloy $\mathrm{X}$ Tested in Air. 


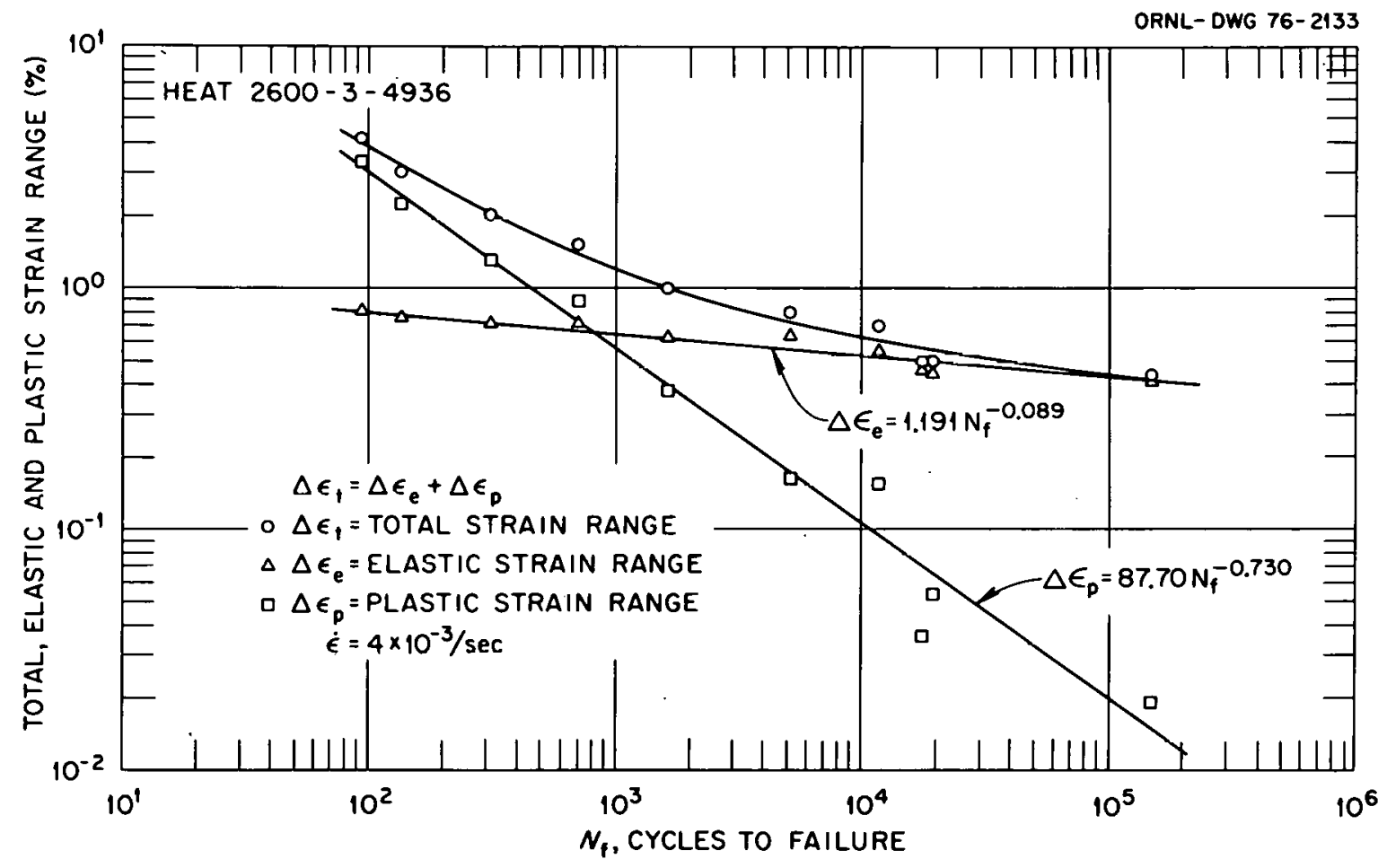

Fig. 16. Total, Elastic, and Plastic Strain Range vs Cycles to Failure at $649^{\circ} \mathrm{C}\left(1200^{\circ} \mathrm{F}\right)$ for Hastelloy $\mathrm{X}$ Tested in Air.

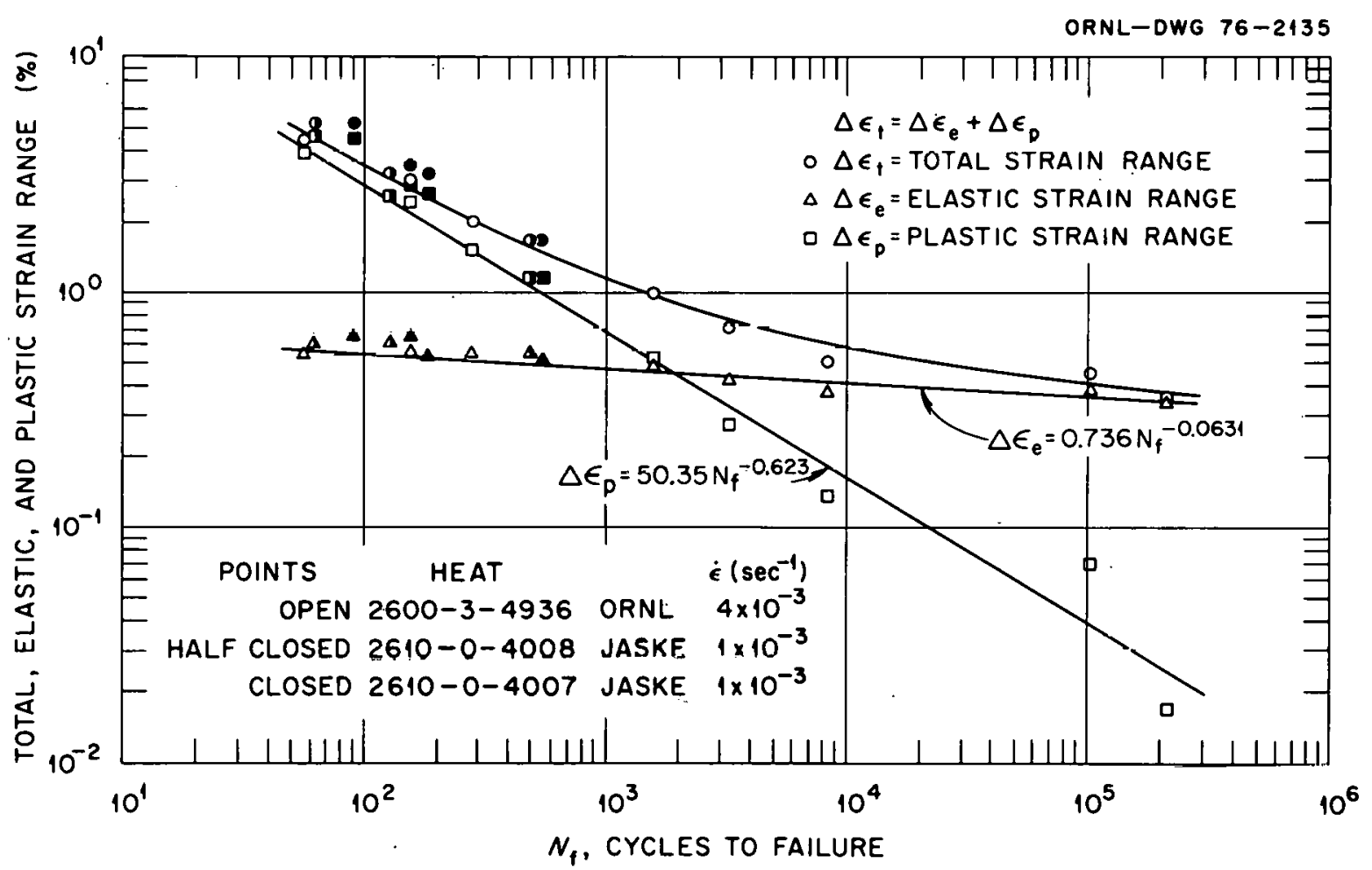

F1g. 17. Total, Elastic, and Plastic Strain Range vs Cycles to Failure at $760^{\circ} \mathrm{C}\left(1400^{\circ} \mathrm{F}\right)$ for Hastelloy. X Tested in Air. 


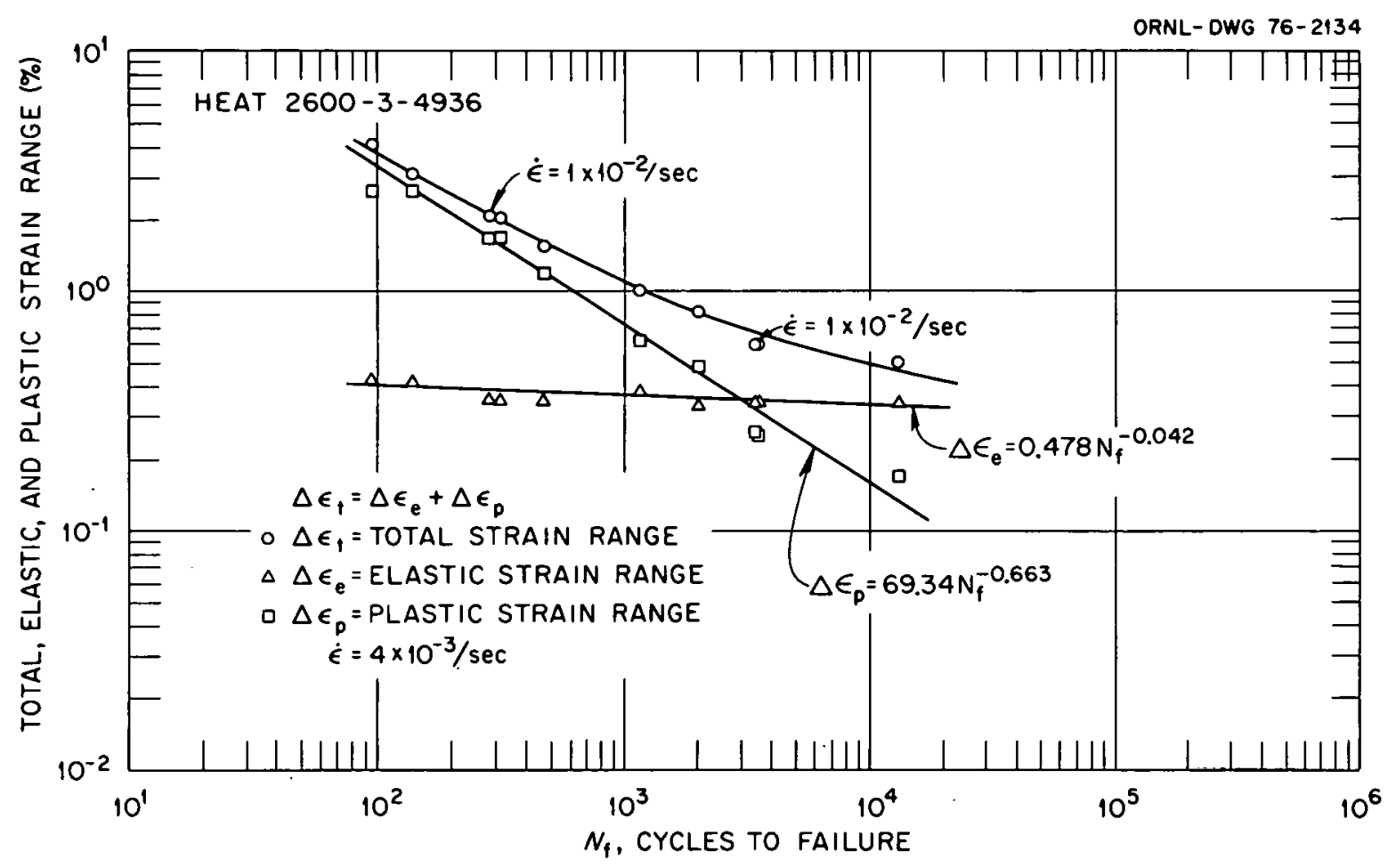

Fig. 18. Total, Elastic, and Plastic Strain Range vs Cycles to Failure at $871^{\circ} \mathrm{C}\left(1600^{\circ} \mathrm{F}\right)$ for Hastelloy $\mathrm{X}$ Tested in Air.

and compressive halves of the cycle. Fatigue data generated to date are given in Tables 8 and 9. Figures 14 to 18 demonstrate that the components of the total strain range, $\Delta \varepsilon_{t}$, namely the plastic, $\Delta \varepsilon_{p}$, and elastic, $\Delta \varepsilon_{e}$, strain ranges, can be expressed as sluple puwer law relationships; thus

$$
\begin{aligned}
& \Delta \varepsilon_{t}=\Delta \varepsilon_{p}+\Delta \varepsilon_{e}, \\
& \Delta \varepsilon_{t}=A N_{f}^{-a}+B N_{f}^{-b} .
\end{aligned}
$$

Values of the coefficlents and exponents in the above equation have been determined by linear least-squares analysis and are summarized in Table 10.

In Fig. 20 a summary comparison best-fit plot is given of the isothermal total strain range vs cycles to failure data. Increasing the temperature generally decreases the continuous-cycling fatigue life of Hastelloy $X$ as shown. Several tests were conducted at a strain rate of $1 \times 10^{-2} / \mathrm{sec}$ at $871^{\circ} \mathrm{C}\left(1600^{\circ} \mathrm{F}\right)$ in order to determine if fatigue life was strain-rate dependent within the creep range at strain rates in excess of $4 \times 10^{-3} / \mathrm{sec}$. The results of the higher strain rate tests gave essentially identical cyclic lives, indicating strain-rate independence for strain rates equal to or in excess of $4 \times 10^{-3} / \mathrm{sec}$. 
ORNL-OWG 75-11066
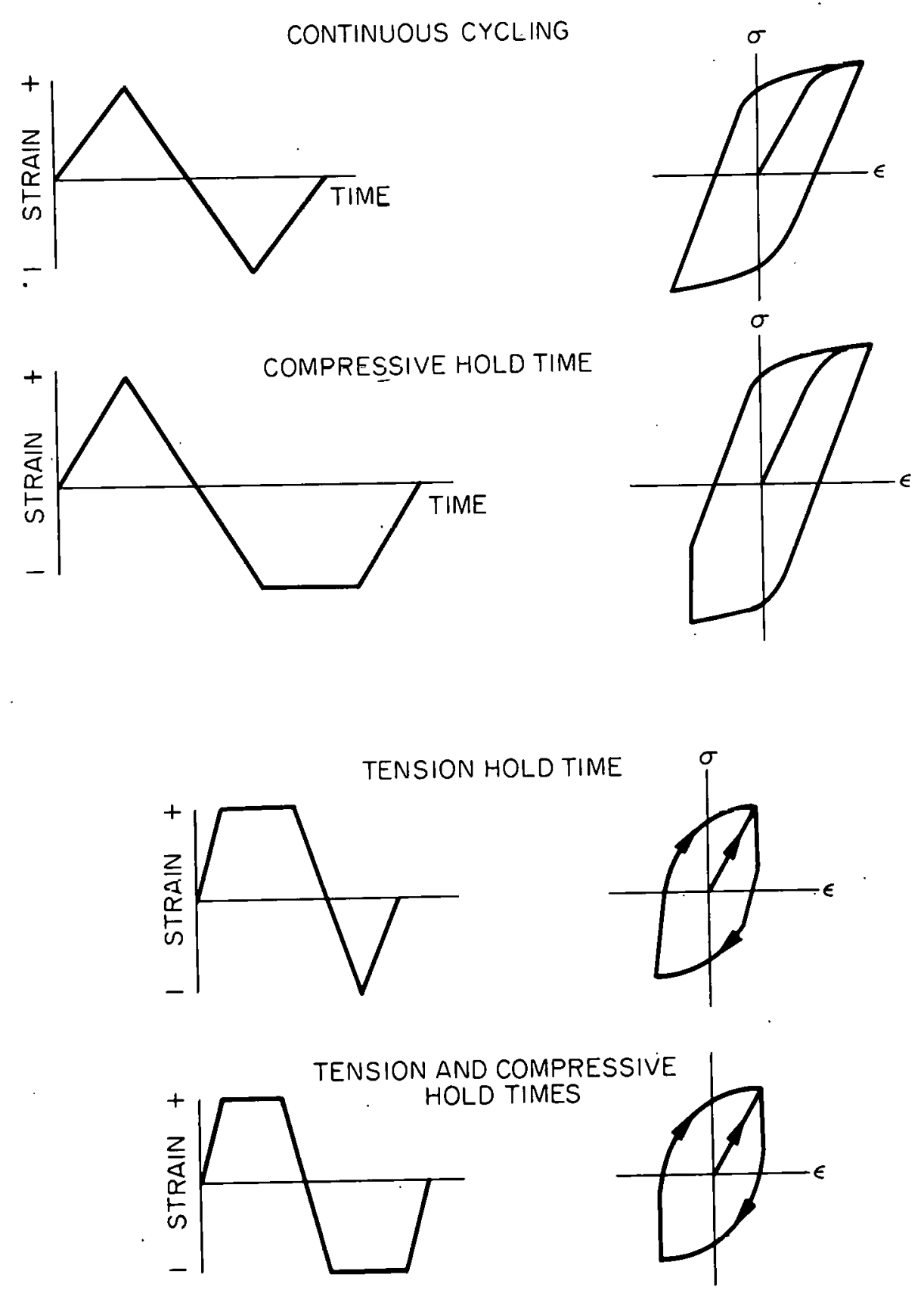

Fig. 19. Strain-Time Wave Forms and Associated Stress-Strain Hysteresis Loops for Fatigue and Creep-Fatigue Tests. 
Table 8. Results of Strain-Controlled Fatigue Tests on Hastelloy X [Heat 2600-3-4936 13-mm (1/2 in.) Plate] Tested in Air ${ }^{a}$

\begin{tabular}{|c|c|c|c|c|c|c|c|c|c|c|c|c|c|c|c|c|}
\hline \multirow[b]{2}{*}{ Spectoen ${ }^{6}$} & \multirow{2}{*}{$\begin{array}{l}\text { Poisson's } \\
\text { Racto. } \\
v\end{array}$} & \multirow{2}{*}{$\begin{array}{c}\text { Total } \\
\text { Strain } \\
\text { Range. } \\
\Delta \varepsilon_{t}\end{array}$} & \multicolumn{4}{|c|}{ Strain Ronge at $N_{f} / 2 . Z$} & \multirow{2}{*}{$\begin{array}{c}\text { Cycles } \\
\text { to } \\
\text { Fallure. } \\
N_{f}\end{array}$} & \multirow{2}{*}{$\begin{array}{c}\tau \text { tme } \\
\text { to } \\
\text { Patlure, } \\
t_{f}\end{array}$} & \multicolumn{2}{|c|}{$\begin{array}{l}\text { Scress Range at } \\
\text { 10th Cycle. } \Delta \sigma_{10} \\
\end{array}$} & \multicolumn{6}{|c|}{ Propert 1es of $N_{f} / 2$. IPe (ks1) } \\
\hline & & & \multicolumn{2}{|c|}{ Elastic, $\Delta \varepsilon_{e}$} & \multicolumn{2}{|c|}{ Inelastic, $\Delta c_{\text {in }}$} & & & (NPS) & (ks1) & Stres: & Ronge ${ }^{c}$ & $\begin{array}{l}\text { Tenail } \\
\text { Napp11t }\end{array}$ & $\begin{array}{l}\text { le Strean } \\
\text { tude, } o_{t}\end{array}$ & $\begin{array}{l}\text { Compreas } \\
\text { napplit }\end{array}$ & $\begin{array}{l}\text { lolve Streese } \\
\text { leude, of }\end{array}$ \\
\hline \multicolumn{17}{|c|}{ Tested at $22^{\circ} \mathrm{C}\left(72^{\circ} \mathrm{F}\right)\left(\right.$ Young's Modulug $E=199 \mathrm{CPa}-28.87 \times 10^{\circ} \mathrm{pa} 1$ ) } \\
\hline ExI-S1 & 0.315 & 4.10 & 0.79 & 0.72 & 3.31 & 3.38 & 439 & 146 & 1292 & 187.4 & 1625 & $(206.7)$ & 6980 & $(101.3)$ & 327 & (105.4) \\
\hline HOCL-29 & 0.265 & 3.04 & 0.76 & 0.70 & 2.28 & 2.34 & 591 & 148 & 1237 & 179.5 & 1392 & (201.9) & 681 & (98.8) & 711 & (103.1) \\
\hline EOC-2B & 0.285 & 2.11 & 0.62 & 0.59 & 1.49 & 1.51 & $\$ .494$ & 249 & 1087 & 157.7 & 117 & $(170.8)$ & 586 & $(84,8)$ & 593 & (86.0) \\
\hline HDC -27 & 0.280 & 1.50 & 0.49 & 0.49 & 1.02 . & 1.02 & 6,101 & 763 & 956 & 138.6 & 958 & $(240.4)$ & 478 & (69.3) & 490 & (71.1) \\
\hline $\mathrm{tXLL}-23$ & 0.278 & 0.99 & 0.46 & 0.43 & 0.53 & 0.56 & 10,245 & 854 & & & 862 & $(125.0)$ & 427 & $(62,0)$ & 435 & (63.1) \\
\hline $\mathrm{ExO}-67$ & 0.261 & 0.89 & 0.48 & 0.42 & 0.41 & 0.47 & 15.796 & 1.185 & 815 & 118.1 & 829 & $(120.3)$ & 407 & $(59.1)$ & 422 & $(61.2)$ \\
\hline $\operatorname{ExL}-22$ & 0.269 & 0.80 & 0.46 & 0.42 & 0.33 & 0.38 & 49.664 & 3,311 & & & 837 & $(121.4)$ & 406 & $(58.9)$ & 431 & $(62.5)$ \\
\hline & & & & Teate & d at $538^{\circ} \mathrm{C}$ & $\left(1000^{\circ} \mathrm{P}\right)$ (Yor & g' a Modulu & $B E=1620$ & $a-23$. & $10^{\circ} \mathrm{pg1}$ & & & & & & \\
\hline HOLL-46 & 0.299 & 4.06 & 0.89 & 0.94 & 3.18 & 3.12 & 177 & 59 & 1084 & 157.2 & 1530 & (221.9) & 748 & $(108.4)$ & 782 & (113.5) \\
\hline (x) 16 & 0.306 & 3.02 & 0.73 & 0.83 & 2.94 & 2.19 & 418 & 104 & 847 & 122.8 & 1353 & (196.3) & 665 & (96.5) & 688 & (99.8) \\
\hline $500-20$ & 0.274 & 1.56 & 0.65 & 0.70 & 0.91 & 0.86 & 1.181 & 148 & 764 & 110.8 & 1141 & (165.5) & 362 & $(81.6)$ & 579 & $(83.9)$ \\
\hline $1000-30$ & 0.302 & 0.99 & 0.62 & 0.63 & 0.37 & 0.36 & 5.182 & 432 & 666 & 96.6 & 1015 & $(147.3)$ & 496 & (71.7) & 521 & $(75.6)$ \\
\hline $\operatorname{ton} 2-3$ & 0.268 & 0.79 & 0.73 & 0.67 & 0.06 & 0.12 & 7,596 & sol & & & 1084 & (157.2) & 493 & (71.5) & 591 & (85.8) \\
\hline HXXT-2 & 0.290 & 0.71 & 0.57 & 0.53 & 0.13 & 0.18 & 14.240 & 831 & 571 & 83.7 & 855 & $(124.0)$ & 405 & $(58.7)$ & 450 & $(65.3)$ \\
\hline ExT -4 & 0.320 & 0.65 & 0.48 & 0.56 & 0.17 & 0.08 & 13.675 & 741 & 542 & 78.6 & 917 & $(133.0)$ & 446 & $(64.7)$ & 471 & (68.3) \\
\hline SxL-19 & 0.341 & 0.60 & 0.56 & 0.54 & 0.04 & 0.06 & 225,000 & 11,250 & & & 877 & $(127.2)$ & 444 & $(64.4)$ & 433 & $(62.8)$ \\
\hline & & & & Tegt & ad at $649^{\circ} \mathrm{C}$ & $\left(1200^{\circ} \mathrm{F}\right)<\mathrm{\gamma o}$ & LB's Moduju & $18 E-154$ & $=22$ & $10^{6} \mathrm{Ps1)}$ & & & & & & \\
\hline $\operatorname{man}-6$ & 0.312 & 4.17 & 0.80 & 0.96 & 3.37 & 3.21 & 94 & 31 & 1118 & 162.3 & 1476 & $(214.0)$ & 719 & $(104.2)$ & 737 & $(109.8)$ \\
\hline $\mathrm{HDC}-14$ & 0.323 & 3.00 & 0.76 & 0.91 & 2.24 & 2.09 & 133 & 33 & 1059 & 153.6 & 1612 & (204.8) & $693<$ & $(100.6)$ & 719 & $(104.2)$ \\
\hline$\$ 21-42$ & 0.316 & 2.03 & 0.72 & 0.82 & 1.31 & 1.21 & 318 & 53 & 872 & 126.5 & 1258 & (182.5) & 611 & (88.6) & 647 & (93.8) \\
\hline $\operatorname{ton}-44$ & 0.334 & 1.52 & 0.63 & 0.72 & 0.89 & 0.80 & 713 & 89 & 712 & 103.1 & 1119 & $(162.3)$ & 567 & (79.3) & 572 & (83.0) \\
\hline $\operatorname{tog}-8$ & n. 305 & 1.00 & 0.63 & 0.63 & 0.38 & 0.37 & 1,617 & 135 & & & 972 & $(141.0)$ & 478 & $(69.3)$ & 694 & $(71.7)$ \\
\hline EXTT-3 & 0.270 & 0.80 & 0.64 & 0.59 & 0.16 & 0.22 & 3.147 & 343 & 628 & 91.1. & 909 & (131.8) & 438 & (63.5) & 471 & $(68.3)$ \\
\hline $\operatorname{taxh}-10$ & 0.308 & 0.70 & 0.55 & 0.54 & 0.15 & 0.16 & 11,764 & 686 & & & 831 & (120.5) & 406 & $(58.9)$ & 425 & $(61.6)$ \\
\hline :xl-7 & 0.325 & 0.50 & 0.45 & 0.47 & 0.05 & 0.03 & 19,262 & 802 & & & 731 & (106.2) & 371 & (53.9) & 360 & (52.3) \\
\hline $\mathrm{ExL}-1$ & 0.258 & 0.50 & 0.46 & 0.46 & 0.04 & 0.04 & 17,820 & 742 & & & 115 & $(103.8)$ & 382 & (55.5) & 333 & $(48.3)$ \\
\hline BRL-15 & 0.381 & 0.44 & 0.62 & 0.45 & 0.02 . & & 148,497 & 5,445 & 454 & 65.9 & 100 & $(101.6)$ & 351 & $(51.0)$ & 349 & $(50.6)$ \\
\hline & & & & Teat & $d$ at $760^{\circ} \mathrm{C}$ & $\left(1400^{\circ} \mathrm{r}\right)$ & LR's Modulu & $18 E \cdot 14$ & - 21. & $\times 10^{6} \mathrm{pg} 12$ & & & & & & \\
\hline $\operatorname{mol}-13$ & 0.321 & 4.48 & 0.54 & 0.70 & 3.94 & 3.78 & 56 & 21 & 966 & 140.1 & 1016 & $(147.4)$ & 494 & (71.7) & 522 & $(75.7)$ \\
\hline $1000-11$ & 0.305 & 3.00 & 0.55 & 0.66 & 2.45 & 2.36 & 154 & 38 & 848 & 123.0 & 935 & (135.7) & 465 & $(67.4)$ & 470 & (68.2) \\
\hline kxL -48 & 0.282 & 2.07 & 0.55 & 0.62 & 1.52 & 1.45 & 280 & 46 & 725 & 105.2 & 902 & $(130.8)$ & 449 & $(65.2)$ & 453 & $(65.6)$ \\
\hline $1000-50$ & 0.316 & 1.50 & 0.50 & 0.55 & 1.00 & 0.95 & 598 & 75 & 663 & 96.2 & 800 & (116.1) & 396 & $(57.4)$ & 404 & $(58.7)$ \\
\hline $8 \times 6-2$ & 0.294 & 1.0 & 0.48 & 0.47 & 0.52 & 0.53 & 1,582 & 132 & & & 684 & $(99.2)$ & 339 & $(49.2)$ & 345 & $(s 0.0)$ \\
\hline (BDO-17 & 0.320 & 0.70 & 0.42 & 0.45 & 0.28 & 0.25 & 3,351 & 195 & & & 655 & $(95.0)$ & 323 & (66.9) & 332 & $(48.1)$ \\
\hline BDo-18 & 0.369 & 0.51 & 0.37 & 0.40 & 0.14 & 0.11 & 8.362 & 348 & 434 & 63.0 & 586 & $(85.0)$ & 293 & (42.5) & 293 & $(42.5)$ \\
\hline ExT-5 & 0.267 & 0.45 & 0.38 & 0.35 & 0.07 & 0.10 & 102,168 & 3.831 & 460 & 66.7 & 518 & $(75.1)$ & 256 & (37.2) & 262 & $(38.0)$ \\
\hline Exa-s & 0.308 & 0.35 & 0.34 & 0.32 & 0.02 & 0.03 & 215.747 & 6.293 & 363 & 52.7 & 476 & $(69.0)$ & 213 & (30.9) & 263 & $(38.1)$ \\
\hline & & & & st & od ac $871^{\circ} \mathrm{C}$ & $\left(1600^{\circ} F\right)\left(\gamma_{0}\right.$ & Ig. B Modulu & $18 E-137$ & -19 & $\left.10^{\circ} \mathrm{ps} 1\right)$ & & & & & & \\
\hline $\operatorname{tax}-41$ & 0.311 & 4.00 & 0.42 & ט.נ & 3.50 & 147 & 9h & 32 & 702 & 101.8 & 720 & $(104.7)$ & 347 & $(50.4)$ & 373 & $(58.0)$ \\
\hline $\cos -40$ & 0.326 & 3.01 & 0.41 & n. 97 & 2.60 & 2.49 & 138 & 34 & 690 & 100.1 & IIS 1 & (103.1) & נ4 & $(h, p)$ & $m$ & (as n \\
\hline $100-33$ & 0.337 & 2.01 & 0.34 & 0.44 & 1.67 & 1,57 & 312 & 52 & 536 & 11.8 & 610 & $(88.5)$ & 298 & $(43.2)$ & 312 & (45.3) \\
\hline txa-53e & 0.319 & 2.00 & 0.35 & 0.96 & 1.65 & 1.56 & 280 & 19 & 609 & 88.4 & 682 & $(99.0)$ & 333 & $(48.3)$ & 349 & $(50.7)$ \\
\hline $\operatorname{Ax} 2-36^{6}$ & 0.298 & 2.00 & & 0.47 & & 1.53 & 216 & 1,332 & 566 & 82.0 & 638 & $(92.6)$ & 318 & $(46,1)$ & 320 & $(46.4)$ \\
\hline $1000-35^{8}$ & 0.329 & 2.00 & & 0.48 & & 1.52 & 185 & 1,141 & 536 & $n 7.7$ & 655 & $(95.0)$ & 333 & (48.2) & 322 & (46.8) \\
\hline $\log -37^{6} \cdot 8$ & 0.320 & 2.00 & & 0.47 & & 1.53 & 196 & 2,384 & 521 & 75.6 & 644 & (93.4) & 319 & (46.3) & 325 & $(47.2)$ \\
\hline HXrT-7 & 0.307 & 1.50 & 0.34 & 0.44 & 1.16 & 1.08 & 466 & 58 & 542 & 78.6 & 604 & $(87.5)$ & 297 & $(43.1)$ & 307 & $(46.5)$ \\
\hline th: \% & 0.305 & 1.00 & 0.38 & 0.38 & 0.62 & 0.62 & 1,156 & 96 & 486 & 70.4 & 523 & (75.8) & 257 & $(37.2)$ & 266 & $(38.6)$ \\
\hline $\ln -54^{h}$ & 0.274 & 0.99 & & 0.389 & & 0.601 & 618 & 9,322 & 417 & 60.5 & 533 & $(77.3)$ & 275 & (39.8) & 258 & $(37.4)$ \\
\hline $800-43$ & 0.307 & 0.80 & 0.32 & 0.35 & 0.48 & 0.45 & 2.002 & 133 & & & 479 & $(69.5)$ & 236 & $(34.2)$ & 283 & (3s.2) \\
\hline $\operatorname{tax}-21$ & 0.270 & 0.39 & 0.36 & 0.33 & 0.25 & 0.26 & 3,433 & 172 & 408 & 59.2 & 452 & $(65.6)$ & 229 & (33.2) & 223 & $(32.4)$ \\
\hline $\log -24^{\circ}$ & 0.279 & 0.59 & 0.34 & 0.34 & 0.25 & 0.25 & 3.494 & 70 & & & 460 & $(66.8)$ & 232 & $(3.3 .6)$ & 228 & (33.2) \\
\hline $\operatorname{lom}-26^{f}, 1$ & 0.253 & 0.60 & & 0.37 & & 0.23 & 2,191 & 13.255 & 385 & 55.8 & 509 & (73.8) & 219 & $(31.8)$ & 290 & (42.1) \\
\hline $\operatorname{lng}-32^{8.1}$ & 0.315 & 0.60 & & 0.37 & & 0.23 & 1,084 & 6,558 & 383 & 55.5 & 510 & $(74.1)$ & 274 & (39.8) & 236 & (34.3) \\
\hline Ben-38 8 & 0.283 & 0.60 & & 0.36 & & 0.24 & 986 & 11,857 & 394 & 57.2 & 495 & (71.8) & 247 & (35.9) & 248 & (35.9) \\
\hline EXT-6 & 0.253 & 0.50 & 0.34 & $0.2 \mathrm{~A}$ & 0.16 & 0.22 & 13,234 & 551 & 374 & 54.3 & 392 & $(56.9)$ & 195 & $(28.3)$ & 197 & $(28.6)$ \\
\hline Etrat & 8. & 1 & 4. & & & & & & & & & & & & & \\
\hline
\end{tabular}


Table 9. Strain-Range Partitioning in Strain-Controlled Fatigue Tests on Hastelloy $\mathrm{X}$ in Air at $871^{\circ} \mathrm{C}\left(1600^{\circ} \mathrm{F}\right)$

\begin{tabular}{|c|c|c|c|c|c|c|c|c|c|}
\hline \multirow{2}{*}{ Specimen } & \multirow{2}{*}{$\begin{array}{c}\text { Strain } \\
\text { Rate } \\
\left.\text { ( } \sec ^{-1}\right)\end{array}$} & \multicolumn{2}{|c|}{ Hold Period, hr } & \multicolumn{2}{|c|}{ Relaxed Stress, MPa (ksi) } & \multicolumn{2}{|c|}{$\begin{array}{c}\text { Partitioned Inelastic } \\
\text { Strain Range, } \%\end{array}$} & \multicolumn{2}{|c|}{$\begin{array}{l}\text { Associated Cycle } \\
\text { Lifetimes, hr }\end{array}$} \\
\hline & & Tensile & Çompressive & Tensile, $\sigma t_{p}$ & Compressive, $\sigma_{c}$ & $\overline{\Delta \varepsilon_{p p}}$ & other & $N_{p p}$ & Other \\
\hline HXL-34 & $4 \times 10^{-3}$ & 0.1 & & $48(7.0)$ & & 1.34 & $\Delta \varepsilon_{c p}=0.20$ & 312 & $N_{c p}=70$ \\
\hline HXL-35 & 4 & & 0.1 & & $38(5.6)$ & 1.31 & $\Delta \varepsilon_{p c}=0.21$ & 320 & $N_{p e}=5 n$ \\
\hline HXL-37 & 4 & 0.1 & 0.1 & $33(4.8)$ & $33(4.8)$ & 1.32 & $\Delta \varepsilon_{c c}=0.21$ & 318 & $N_{c c}=58$ \\
\hline HXL-54 & 4 & & 0.25 & & $38(5.6)$ & 0.44 & $\Delta \varepsilon_{p c}=0.16$ & 1,746 & $N_{p c}=222$ \\
\hline HXL-26 & 9 & 0.1 & & $57(8.3)$ & & 0.11 & $\Delta \varepsilon_{c p}=0.11$ & 15,039 & $N_{c p}=1221$ \\
\hline HXL-32 & 9 & & 0.1 & & $49(7.1)$ & 0.090 & $\Delta \varepsilon_{p c}=0.14$ & 20,604 & $N_{p c}=669$ \\
\hline HXXL-38 & 4 & 0.1 & 0.1 & $26(3.9)$ & $30(4.3)$ & 0.079 & $\Delta \varepsilon_{c c}=0.16$ & 25,228 & $N_{c e}=667$ \\
\hline
\end{tabular}

${ }^{a}$ Based on calculated tnelastic strain range.

Table 10. Values for the Elastic and Plastic Strain Range Constants for Strain-Controlled Tests Conducted on Hastelloy $\mathrm{X}$ at a Strain Rate of $4 \times 10^{-3} / \mathrm{sec}$

\begin{tabular}{|c|c|c|c|c|c|c|}
\hline \multirow[t]{2}{*}{ Heat } & \multicolumn{2}{|c|}{ Temperature } & \multicolumn{4}{|c|}{$\begin{array}{l}\text { Values of Constants in } \\
\Delta \varepsilon_{t}=A N_{f}^{-a}+B N_{f}^{-b}\end{array}$} \\
\hline & $(C)$ & $(F)$ & $A$ & $a$ & $B$ & $b$ \\
\hline $2600-3-4936$ & Room & Room & 56.75 & 0.489 & 1.607 & 0.126 \\
\hline $2600-3-4936$ & 538 & 1000 & 88.92 & 0.665 & 1.089 & 0.0633 \\
\hline $2600-3-4936$ & 649 & 1200 & 87.70 & 0.730 & 1.191 & 0.0890 \\
\hline $2600-3-4936$ & 700 & 1400 & 50.35 & 0.623 & 0.736 & 0.0631 \\
\hline $2600-3-4936$ & 871 & 1600 & 69.34 & 0.663 & 0.478 & 0.0420 \\
\hline
\end{tabular}




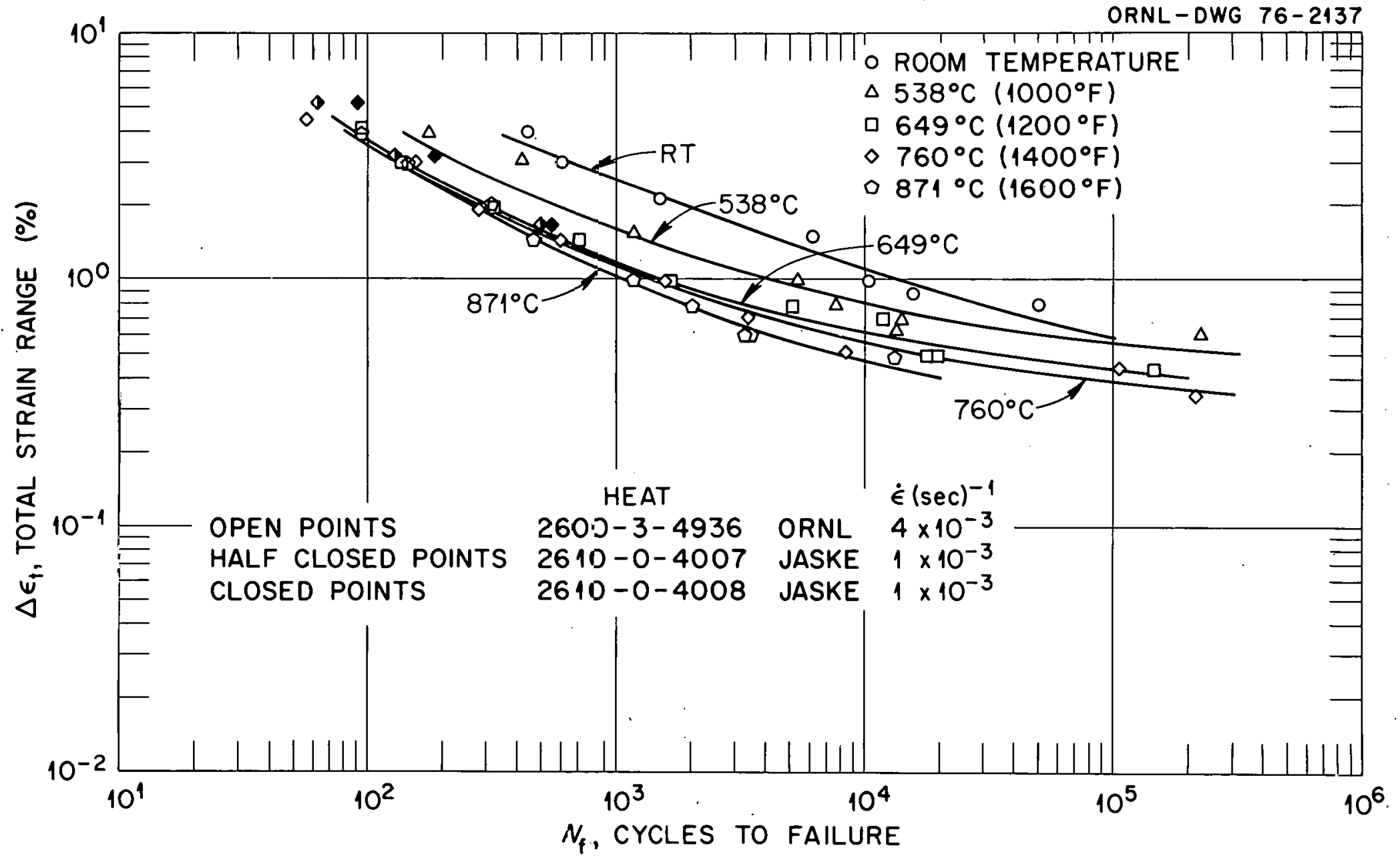

Fig. 20. Total Strain Range vs Cycles to Failure for Hastelloy X Tested in Air. 
Since other structural materials ${ }^{21,22}$ will be used for various components within HTGR systems, it was thought instructive to make comparisons between the continuous-cycling fatigue properties of Hastelloy $X$ and a number of these materials. These materials include Inconel alloy $718,{ }^{23}$ Incoloy alloy $800,{ }^{24-27} 21 / 4 \mathrm{Cr}-1$ Mo steel, 28 type 304 stainless steel, 24-27,29,30 type 316 stainless steel,24,26,31 and AISI 1010 steel. ${ }^{32}$ Product forms from which the data were generated, along with several tensile properties of interest in fatigue analysis at temperatures where comparisons can be made, are given in Table 11 . All data were generated in air at a continuous-cycling strain rate of $4 \times 10^{-3} / \mathrm{sec}$. Comparative plots are given in Figs. 21-23. Values of

${ }^{21} \mathrm{P}$. L. Rittenhouse, Initial Assessment of the Status of HTGR MetalZic Stmuctural Materials Technology, ORNL-TM-4760 (December 1974).

${ }^{22}$ P. L. Rittenhouse and C- S. Morgan, Status Report on Structural Materials of HTGR Primary System Components, ORNL/TM-5136 (January 1976).

${ }^{23} \mathrm{C}$. R. Brinkman and G. E. Korth, "Strain Fatigue and Tensile Behavior of Inconel 718 from Room Temperature to $650^{\circ} \mathrm{C}, " \mathrm{~J}$. Test. Eval. 2(4) : 249-59 (July 1974).

${ }^{24} \mathrm{~J}$. B. Conway, R. H. Stentz, and J. T. Berling, Fatigue, Tensize and Relaxation Behavior of Stainless Steels, USAEC TID-26135, Division of Reactor Research and Development, U.S. Atomic Energy Commission (1975).

${ }^{25}$ D. L. Keller, Progress on LMFBR Cladding, Structural, and Component Material Studies During July 1971 Through June 1972 - Final Report Task 32, BMI-1928, Battelle Columbus Laboratories.

${ }^{26} \mathrm{D}$. L. Keller, Progress on LMFBR Cladding, Structural, and Component Materials Studies During July 1970 Through June 1971 - Annual Report, Task 32, Final Report, Task 14, BMI-1914, Battelle Columbus Laboratories.

${ }^{27}$ Component and Systems Development Progrom, Quart. Prog. Rep. June 30, 1975, GA-A13512, General Atomic Company.

${ }^{28} \mathrm{C}$. R. Brinkman et a1., Interim Report on the Continuous cycling Elevated-Temperature Fatigue and Subcritical. Crack Growth Behavior of 2 1/4 Cr-1 Mo Steel, ORNL-TM-4993 (December 1975).

${ }^{29}$ Personal communication with D. R. Diercks, January 1976.

${ }^{30} \mathrm{C}$. R. Brinkman and G. E. Korth, Heat-to-Heat Variations in the Fatigue and Creep-Fatigue Behavior of AISI Type 304 Stainless Steel, and the Fatigue Behavior of Type 308 Stainless Steel Weld Material.s, ANCR-1097 Aerujet Nuclear Company (May 1973).

${ }^{31} \mathrm{C}$. R. Brinkman, G. E. Korth, and R. R. Hoblins, "Estimates of CreepFatigue Interaction in Irradiated and Unirradiated Austenitic Stainless Steels," Nucl. Technol. 16: 297-307 (October 1972).

${ }^{32} \mathrm{C}$. E. Jaske, "Low Cycle Fatigue of AISI 1010 Steel at Temperatures up to $1200^{\circ} \mathrm{F}\left(649^{\circ} \mathrm{C}\right), "$ to be presented at American Society of Mechanical Engineers International Joint Pressure Vessels and Piping and Petroleum Mechanical Engineering Conference, September 19-24, 1976, Mexico City, Mexico. 
Table 11. Comparison of Several Tensile Properties

(average values) of Several Structural Materials Used in Nuclear Reactor Construction

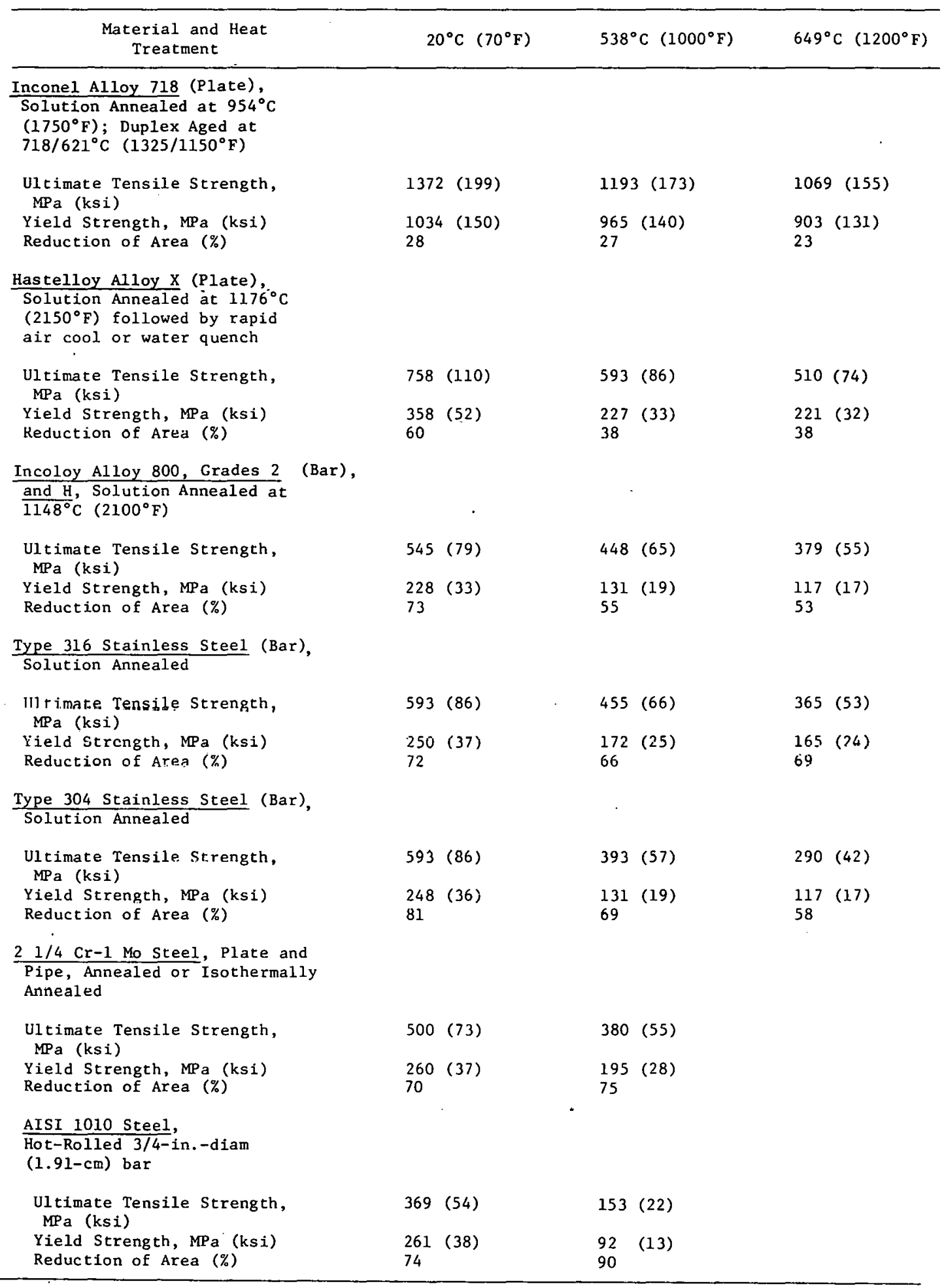




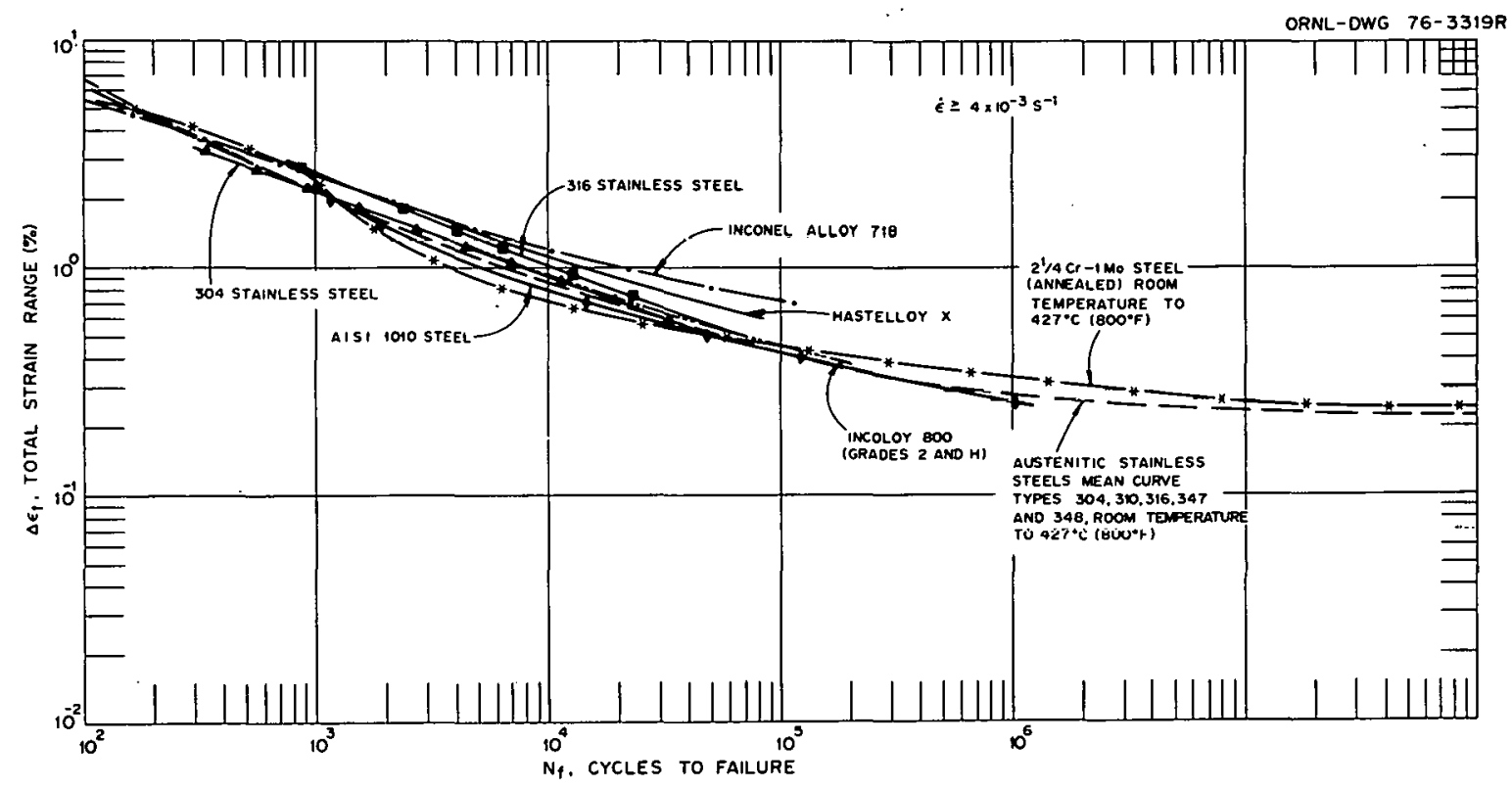

Fig. 21. Comparison of the Fatigue Behavior of Several Materials at Room Temperature (Except as Indicated). Lines represent best-fit values of actual data.

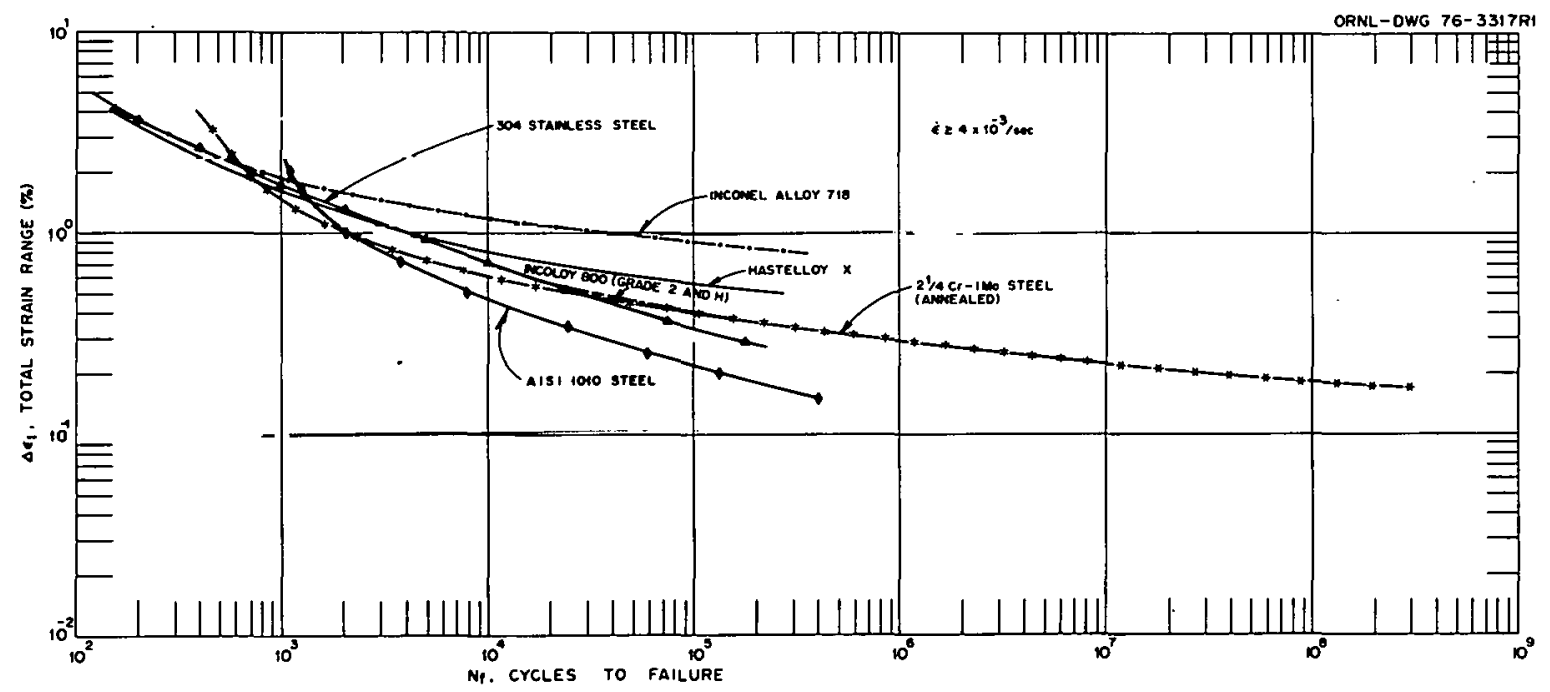

Fig. 22. Comparison of the Fatigue Behavior of Several Materials at $538^{\circ} \mathrm{C}\left(1000^{\circ} \mathrm{F}\right)$. Lines represent best-fit values of actual data. Data for type 304 stainless steel include tests conducted at $538^{\circ} \mathrm{C}\left(1000^{\circ} \mathrm{F}\right)$ and $566^{\circ} \mathrm{C}\left(1050^{\circ} \mathrm{F}\right)$. 


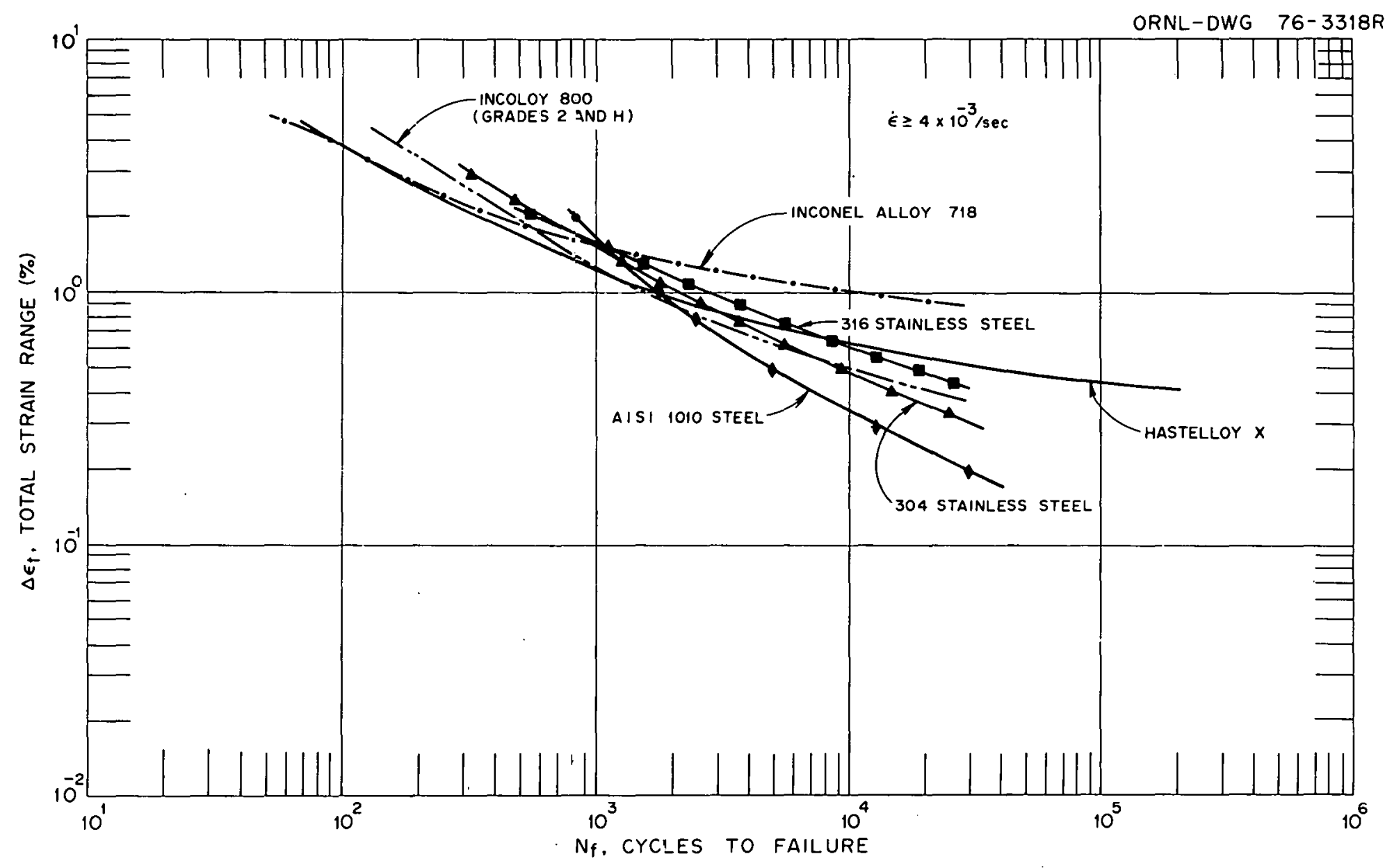

Fig. 23. Comparison of the Fatigue Behavior of Several Materials at $649^{\circ} \mathrm{C}\left(1200^{\circ} \mathrm{F}\right)$. Lines represent best-fit values of actual data. 
the constants defining equations for Hastelloy $\mathrm{X}$ are given in $\mathrm{Tab}$ le 10 , while equations for other materials are given in the Appendix.

Comparing the continuous-cycling fatigue of these materials in Figs. 21-23 indicates similar low-cycle fatigue behavior in the lowcycle range, even though they show wide differences in ductility, particularly at room temperature. However, as the total strain range is reduced, marked differences in fatigue life occur which are accentuated by increasing the temperature. High-cycle fatigue resistance is a function of the ultimate tensile strength, and, therefore, Inconel alloy 718 , having the highest value, shows the best high-cycle fatigue resistance, with Hastelloy $X$ showing the second best.

In addition to continuous-cycling fatigue tests, hold periods at constant strain (see Fig. 19) and load are being introduced each cycle in order to determine the influence of creep-fatigue and environmental interaction on the flow and failure behavior of Hastelloy X. Generally, the technique of strain range partitioning ${ }^{33,34}$ is being used as a guide in developing the necessary data. The experimental steps in order to generate the data so that the fatigue life of any complex cycle at temperatures within the creep range might be predicted are as follows:

1. generate curves for various inelastic strain modes, that is, $\Delta \varepsilon_{p p}$, $\Delta \varepsilon_{c p}, \Delta \varepsilon_{p c}$, and $\Delta \varepsilon_{c c}$;

2. conduct tests with mixed strain modes (two) to verify position of lines (single temperature);

3. conduct tests at several temperatures, including peak expected operating temperature (normal or accident) to verify damage lines;

4. conduct complex hysteresis loop tests;

5. conduct long-term tests for verification;

6. conduct environmental tests to determine impact of particular environments;

where

$\Delta \varepsilon_{p p}=$ range of tensile plasticity reversed by compressive plasticity strain or width of the hystersis loop generated at high enough strain rates to preclude creep or strain-rate effects; in Hastelloy $\mathrm{X}$ over the temperature range of interest, strain rates equal to or in excess- of $4 \times 10^{-3} / \mathrm{sec}$ were shown to be acceptable for this purpose;

${ }^{33}$ S. S. Manson, G. R. Halford, and M. H. Firshberg, "Creep-Fatigue Analysis by Strain-Range Partitioning," pp. 12-28 in Symposium on Design for Elevated Temperature Environments, ed. by S. Y. Zamrik, American Society of Mechanical Engineers, New York, 1971.

${ }^{34} \dot{M}$. H. Hirshberg and G. R. Halford, "Use of Strain-Range Partitioning to Predict High-Temperature Low-Cycle Fatigue Life," NASA Lewis Research Center, Cleveland, Ohio (to be published). 
$\Delta \varepsilon_{c p}=$ range of tensile creep reversed by compressive plasticity strain generated in work to date by tensile strain hold-time tests; however, other tests imposing load holds will also be conducted;

$\Delta \varepsilon_{p c}=$ range of tensile plasticity strain reversed by compressive creep strain; obtained from compressive hold-time tests; to date, only strain hold-time tests have been conducted;

$\Delta \varepsilon_{c c}=$ range of tensile creep reversed by compressive creep; obtained from tests in which a hold is introduced during both the tensile and compressive halves of each cycle; only strain holds have been conducted to date.

At this time, only a limited number of hold-time tests, all in the strain-controlled mode, have been conducted on Hastelloy $X$. The tests were conducted at $871^{\circ} \mathrm{C}\left(1600^{\circ} \mathrm{F}\right)$, and the interim data are reported in Table 9. Hysteresis loops at roughly half the cycle life for two strain ranges (i.e., 2 and $0.6 \%$ ) are compared with those generated without hold periods in Fig. 24, which shows for the $0.6 \%$ total strain range that tests conducted with a tensile hold time only developed a mean compressive stress and that tests conducted with a compressive hold period developed a mean tensile stress; while for a test generated with both a tensile and compressive hold, little or no mean stress was developed. Figure 24 also shows that compressive hold times tend to be the most damaging mode.

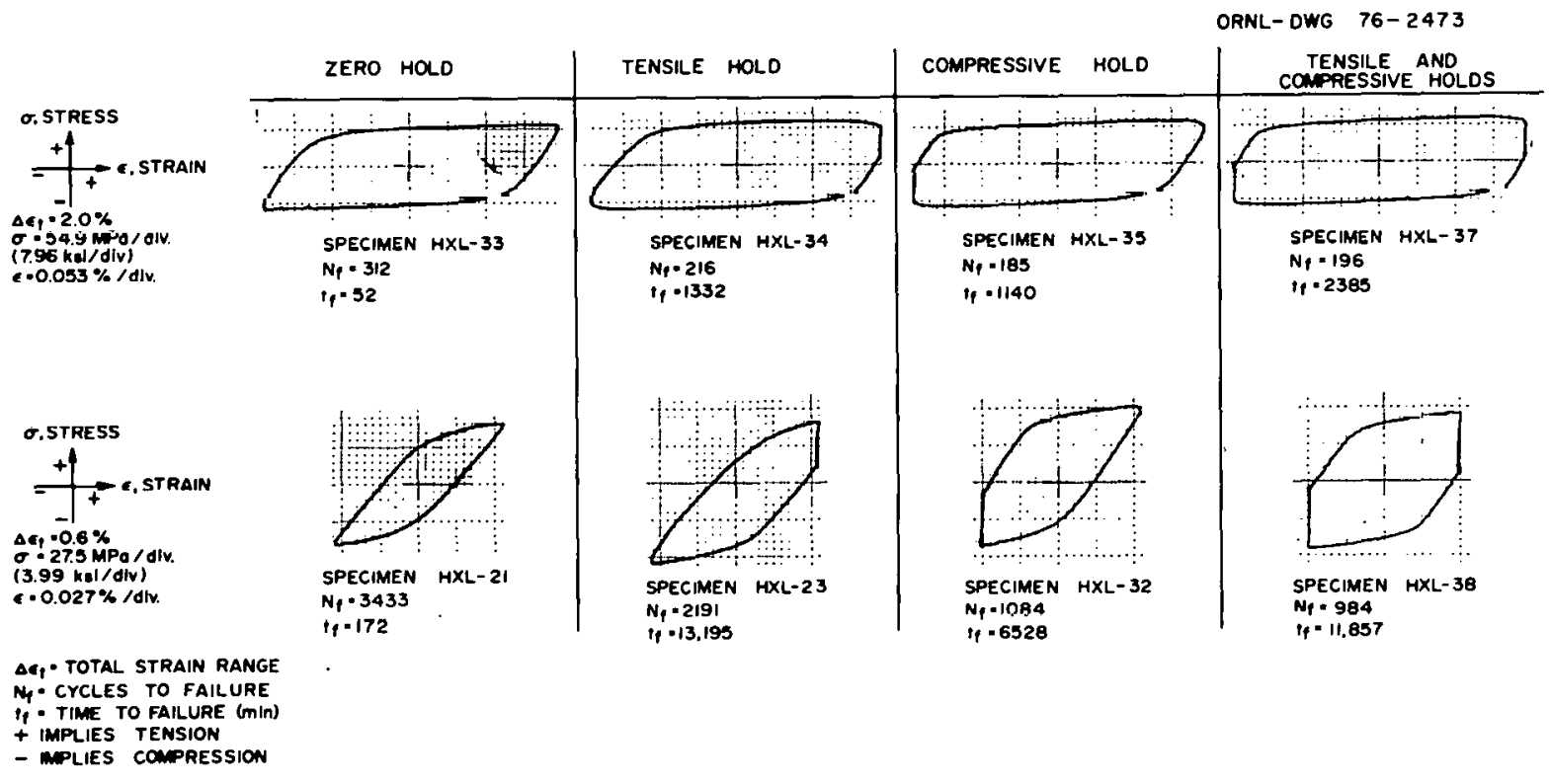

Fig. 24. Comparison of Actual Hysteresis Loops from Strain-Controlled Low-Cycle Fatigue Tests Involving Zero Hold Periods or 0.1-hr Hold Periods at Peak (Maximum, Minimum, or Both) Strain Amplitudes. Tests were conducted on Hastelloy $X$ (Heat $2600-3-4936)$ at $871^{\circ} \mathrm{C}\left(1600^{\circ} \mathrm{F}\right.$ ) in air. 
Lord and Coffin ${ }^{35}$ characterized the low-cycle fatigue and hold-time behavior of cast Rene' 80 and found that compressive hold times were more damaging than tensile hold times. They qualitatively explained this behavior in terms of the ability of the material to sustain a mean stress at cycle lives beyond the transition fatigue life; that is, the elastic strain range was greater than the plastic strain range. They postulated that in this material, compressive hold times were particularly deleterious at low strain ranges, because tensile mean stresses could be maintained which enhanced crack growth rates. For Haste11.oy $X$ tested at $871^{\circ} \mathrm{C}\left(1600^{\circ} \mathrm{F}\right)$, the cycle life of a continuously cycled specimen tested at $0.6 \%$ total strain range is greater than the transition fatigue life. Therefore, the above explanation as to why compressive hold times are more damaging than tensile hold times is plausible.

Plots of the inelastic strain components from tests conducted to date are given in Fig. 25. Only data in the range $649^{\circ} \mathrm{C}\left(1200^{\circ} \mathrm{F}\right.$ ) to $871^{\circ} \mathrm{C}\left(1600^{\circ} \mathrm{F}\right)$ are included in this plot. The $\Delta \varepsilon p p$ plastic strain data obtained from tests conducted at temperatures of $538^{\circ} \mathrm{C}\left(1000^{\circ} \mathrm{F}\right)$ and lower were excluded from the plot, since values clearly fell above the high-temperature data.

Cyclic lines associated with the various components of timedependent inelastic strain, that is, $N_{c p}, N_{p c}$, and $N_{c c}$, were calculated
using the interaction damage rule: ${ }^{36}$

$$
\frac{F_{p p}}{N_{p p}}+\frac{F_{p c}}{N_{p c}}+\frac{F_{c p}}{N_{c p}}+\frac{F_{c c}}{N_{c c}}=\frac{1}{N_{f}},
$$

where

$$
\begin{aligned}
& F_{p p}=\Delta \varepsilon_{p p} / \Delta \varepsilon_{\text {in }}, \\
& F_{p c}=\Delta \varepsilon_{p c} / \Delta \varepsilon_{\text {in }},
\end{aligned}
$$

${ }^{35}$ D. C. Lord and L. F. Coffin, Jr., "Low-Cycle Fatigue Hold Time Behavior of Cast Rene' 80," MetalZ. Trans. 4: 1647 (1973).

${ }^{36}$ S. S. Manson, "The Challenge to Unify Treatment of High Temperature Fatigue - A Partisan Proposal Based on Strain Range Partitioning," pp. 744-75 in Fatigue at Elevated Temperatures, Am. Soc. Test. Mater. Spec. Tech. Publ. 520, ed. by A. E. Cardin, A. J. McEvily, and C. Wells, American Society for Testing and Materials, Philadelphia, 1973. 


$$
\begin{aligned}
& F_{c p}=\Delta \varepsilon_{c p} / \Delta \varepsilon_{\text {in }}, \\
& F_{c c}=\Delta \varepsilon_{c c} / \Delta \varepsilon_{\text {in }},
\end{aligned}
$$

$$
\begin{aligned}
\Delta \varepsilon_{\text {in }}= & \text { total inelastic strain range associated with the } \\
& \text { particular cycle being analyzed. }
\end{aligned}
$$

Tests in air are continuing, and tests in helium will begin in the near future.

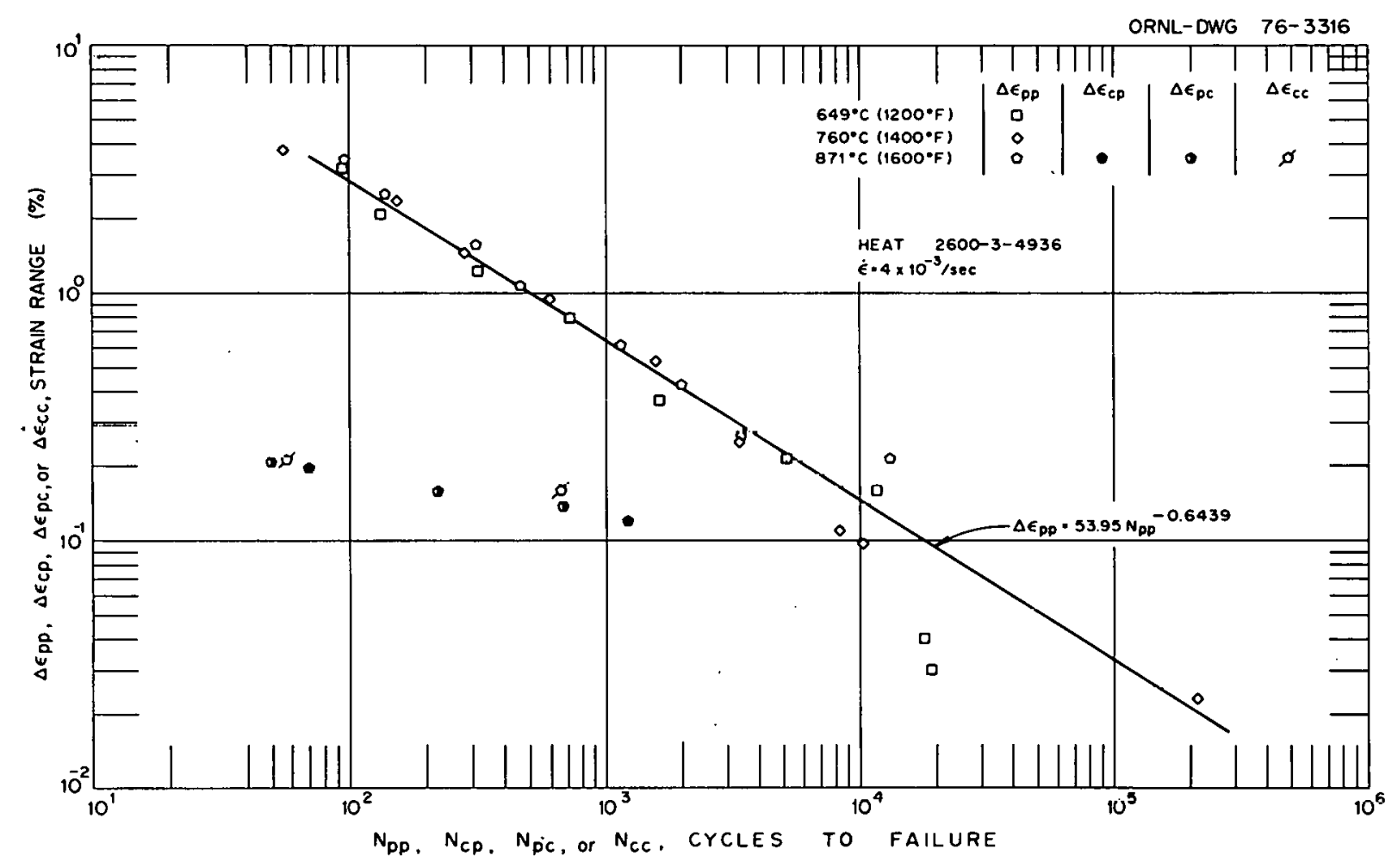

Fig. 25. Partitioned Inelastic Strain Components vs Associated Figure Lifetimes For Hastelloy X. 


\section{SUBCRITICAL CRACK GROWTH}

Numerous investigations ${ }^{37-41}$ have shown that the fatigue behavior of structural alloys, specifically the crack growth rate, is dependent on the test environment in addition to the more conventional parameters of temperature, frequency, and mean stress level. To determine the effects of simulated HTGR primary coolant on the fatigue crack propagation behavior of Hastelloy $\mathrm{X}$, tests were conducted in air at 25, 538, and $649^{\circ} \mathrm{C}\left(77,1000\right.$, and $\left.1200^{\circ} \mathrm{F}\right)$, and comparative tests were conducted in HTGR helium at the elevated temperatures. All tests had an $R$ ratio (ratio of minimum to maximum stress intensity) of 0.05 and were run at a frequency of $1 \mathrm{~Hz}$ at the elevated temperatures. and $40 \mathrm{~Hz}$ at room temperature, where thermally induced processes are largely inactive. The results are shown in Figs. 26-28. Data on Hastelloy X 280, a lowcobalt version of Hastelloy $X$, is shown for comparison at room temperature and at $538^{\circ} \mathrm{C}\left(1000^{\circ} \mathrm{F}\right) .{ }^{42}$

No difference in crack growth rate was observed in simulated HTGR helium at either of the elevated test temperatures when compared with results obtained in air with specimens of similar geometry. However, a systematic, reproducible difference was observed at all temperatures between the compact tension and the WOL specimens. A similar effect has been observed in a previous study $^{14}$ using the same specimen geometries. It is probably due to a slight departure from linear elastic fracture mechanics testing conditions within the small compact tension specimen in as much as an excessively large plastic zone is generated, relative to the planar specimen dimensions. Hence, the calculated value of stress intensity is not strictly valid. None the less, comparison of crack growth rates using the compact tension specimen in both air and simulated HTGR helium indicates no difference in crack growth rates as shown in Figs. 27 and 28.

Averaged results of both test geometries are given in Fig. 29 for all test temperatures. Crack growth rate is clearly shown to increase with increasing temperature at a constant level of $\Delta k$.

${ }^{37}$ H. H. Smith, P. Shahinian, and M. R. Achter, Trans. AIME 245: 947 (1969).

${ }^{38}$ M. R. Achter, G. J. Danek, Jr., and H. H. Smith, Trans. AIME 227: 1296 (1963).

${ }^{39} \mathrm{~L}$. A. James and R. L. Knecht, "Fatigue-Crack Propagation Behavior of Type 304 Stainless Steél in a L1quid Sodium Environment," Metaiz. Trans. 6a(1): 109-16 (1975).

"10. A. James and R. L. Knecht, Subcritical Crack Growth, HEDL-TME 74-4, HEDL Quarterly Technical Report, 1: C13-C19 (January 1975).

${ }^{41}$ W. R. Corwin, "Subcritical Crack Growth Studies," Mechanical Properties Test Data for Structural Materials Q. Prog. Rep. Oct. 31, 1975, ORNL-5107, pp. 196-201.

${ }^{42}$ L. A. James, The Effect of Temperature Upon the Fatigue-Crack Propagation Behavior of HasteZZoy X-280, HEDL-TME 76-40 (May 1976). 


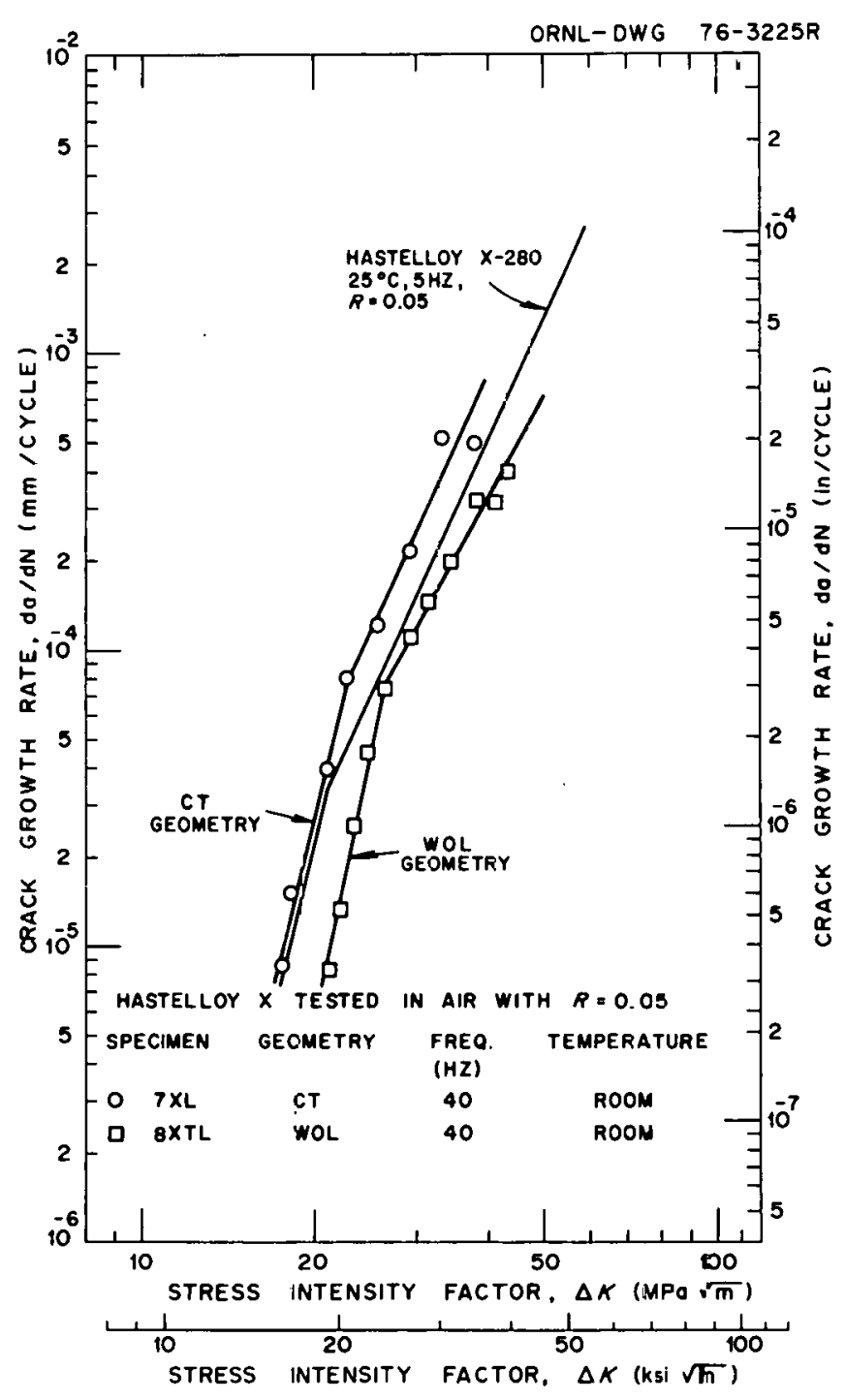

Fig. 26. Effect of Specimen Geometry on Fatigue Crack Growth Rate at Room Temperature.

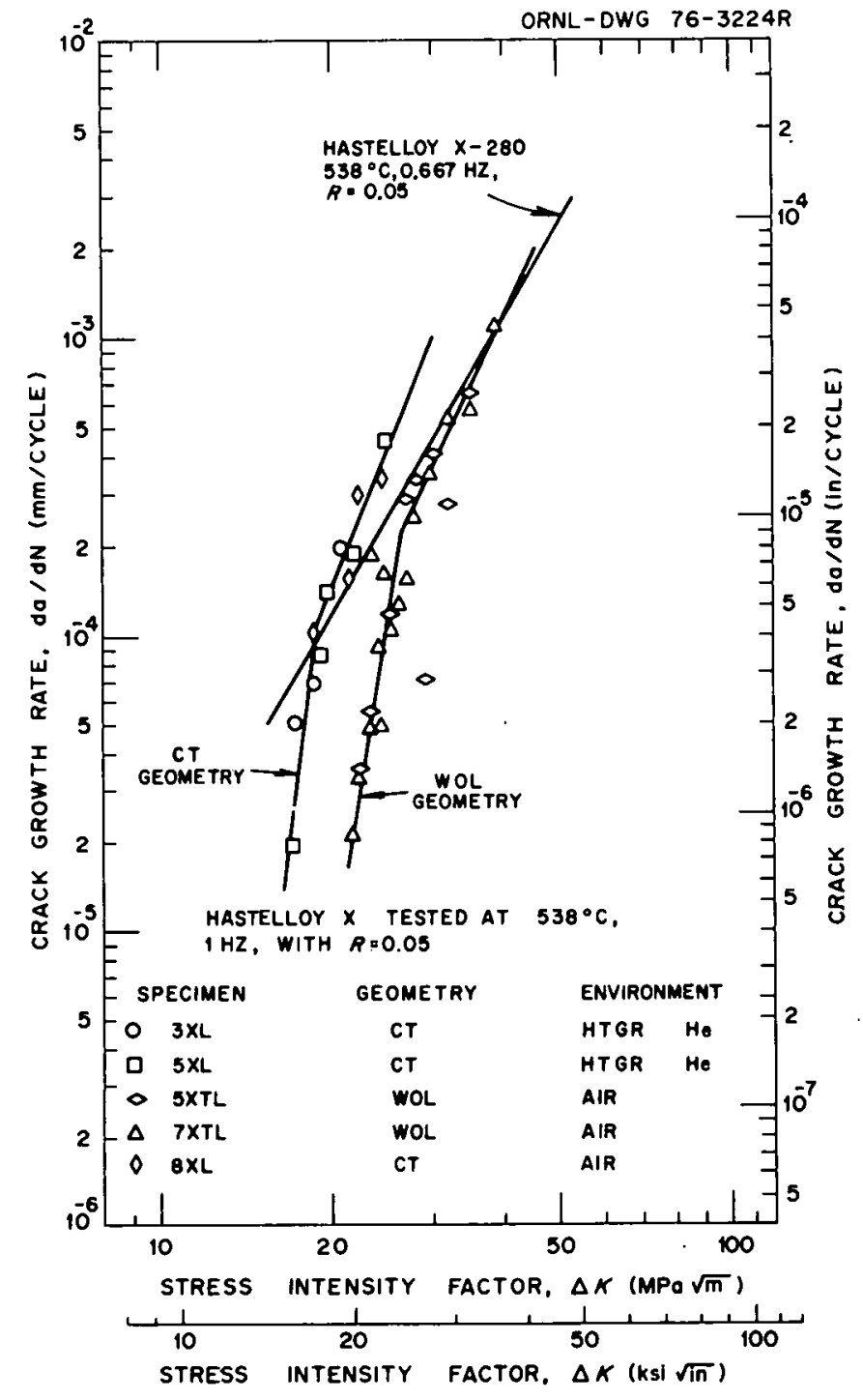

Fig. 27. Effect of Simulated HTGR Primary Coolant and Specimen Geometry on Fatigue Crack Growth Rate at $538^{\circ} \mathrm{C}\left(1000^{\circ} \mathrm{F}\right)$. 


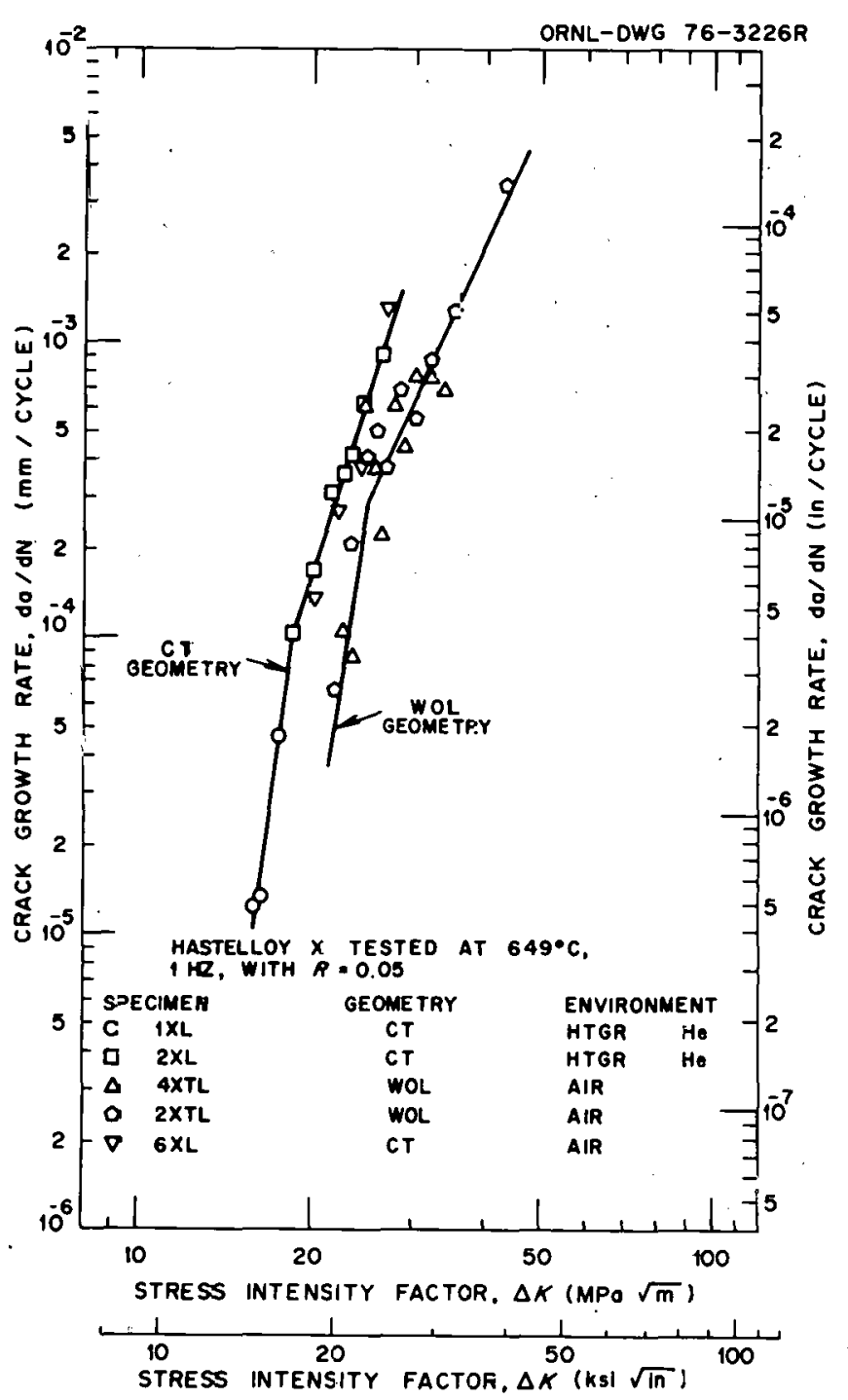

Fig. 28. Effect of Simulated HTGR Primary Coolant and Specimen Geometry on Fatigue Crack Growth Rate at $649^{\circ} \mathrm{C}\left(1200^{\circ} \mathrm{F}\right)$.

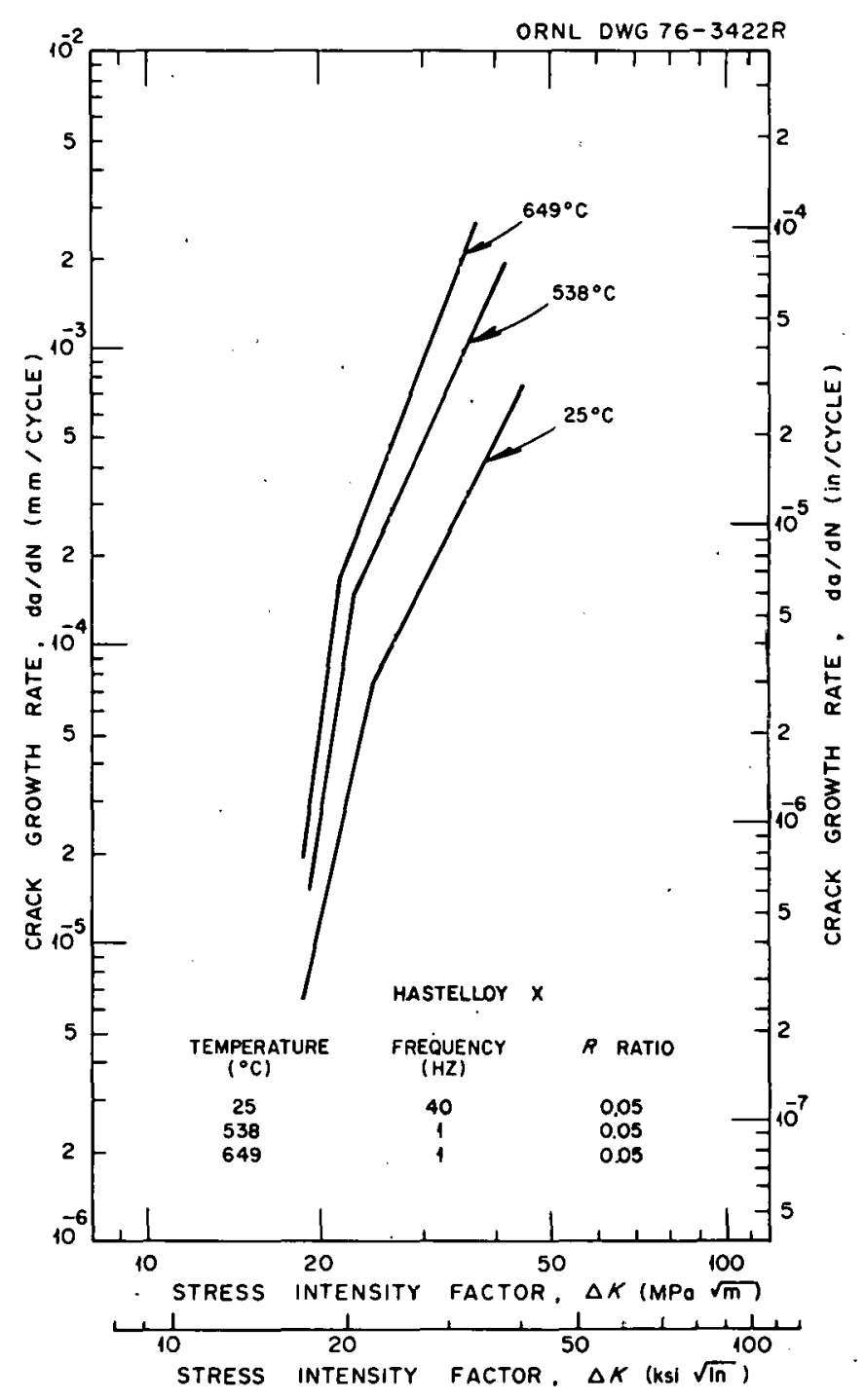

Fig. 29. Effect of Temperature on the Averaged Fatigue Crack Growth Behavior of Hastelloy $\mathrm{X}$. 
Results obtained at $538^{\circ} \mathrm{C}\left(1000^{\circ} \mathrm{F}\right)$ for Hastelloy $\mathrm{X}$ are compared in Fig. 30 with those for several other structural materials which are candidates for use in the HTGR and other reactor systems. The data for types 304 (ref. 43) and 316 (ref. 44) stainless steel, Inconel 718 (ref. 45) and Incoloy 800 (ref. 46) are all results obtained at $538^{\circ} \mathrm{C}$ $\left(1000^{\circ} \mathrm{F}\right)$. The line of $d a / d N$ vs $\Delta K$ for $21 / 4 \mathrm{Cr}-1$ Mo steel ${ }^{41}$ was obtained by linear interpolation of results at 510 and $593^{\circ} \mathrm{C}\left(950\right.$ and $\left.1100^{\circ} \mathrm{F}\right)$ and is also shown for comparison. Overall, Inconel alloy 718 shows the lower crack growth rate for most of the stress intensity values in comparison with the other materials at this temperature. The reasons for differences in crack growth rates for a given stress intensity displayed by the seven materials compared in Fig. 30 are not readily apparent. Pelloux, ${ }^{47}$ in reviewing the various theories and laws of fatigue crack propagation, showed crack growth rates to be a function of many factors, including the plastic zone size and the shape at the tip of the crack, as well as the cyclic stress-strain hardening behavior of the material. ' In this respect, crack growth rates tend to be inversely proportional to the yield strength. Table 11 shows that at $538^{\circ} \mathrm{C}\left(1000^{\circ} \mathrm{F}\right)$, Incone 1 alloy 718 has a much higher yield strength than the other materials shown and therefore generally displays the lower crack growth rate for a given stress intensity.

Thermal Stability

As was indicated previously, the design lifetime of an HTGR plant is set at $280,000 \mathrm{hr}$. Therefore, the long-term elevated-temperature stability of any candidate alloy such as Hastelloy $\mathrm{X}$ proposed for elevatedtemperature service in HTGR systems is important. Hastelloy $X$ is a

${ }^{43}$ L. A. James, "Fatigue Crack Growth in Type 304 Stainless Steel Weldments at Elevated Temperatures," J. Test. Eval. 1(1): 52-57

(January 1973).

${ }^{44} \mathrm{~L}$. A. James, "The Effect of Elevated Tempcrature upon the FatigueCrack Propagation Behavior of Two Austenitic Stainless Steels," pp: 341-52 in Mechanical Behavior of Materials, vol. III, Society of Materlals Science, Japan, 1972.

${ }^{45}$ L. A. James, Fatigue Crack Propagation Behavior of Inconel 728, HEDL-TME 75-80 (in press).

${ }^{46} \mathrm{~L}$. A. James, "Fatigue-Crack Growth of Incoloy 800 at Elevated Temperatures," J. Eng. Mater. Technol. 96(4): 249-54 (1974).

${ }^{47}$ R. M. Pelloux, "Review of Theories and Laws of Fatigue Crack Propagation," Proceedings of the Air Force Conference on Fatigue and Fracture of Aircraft Structures and Materials, AFFDL TR 70-144, Miami Beach, Florida, 15-18 December 1969. 


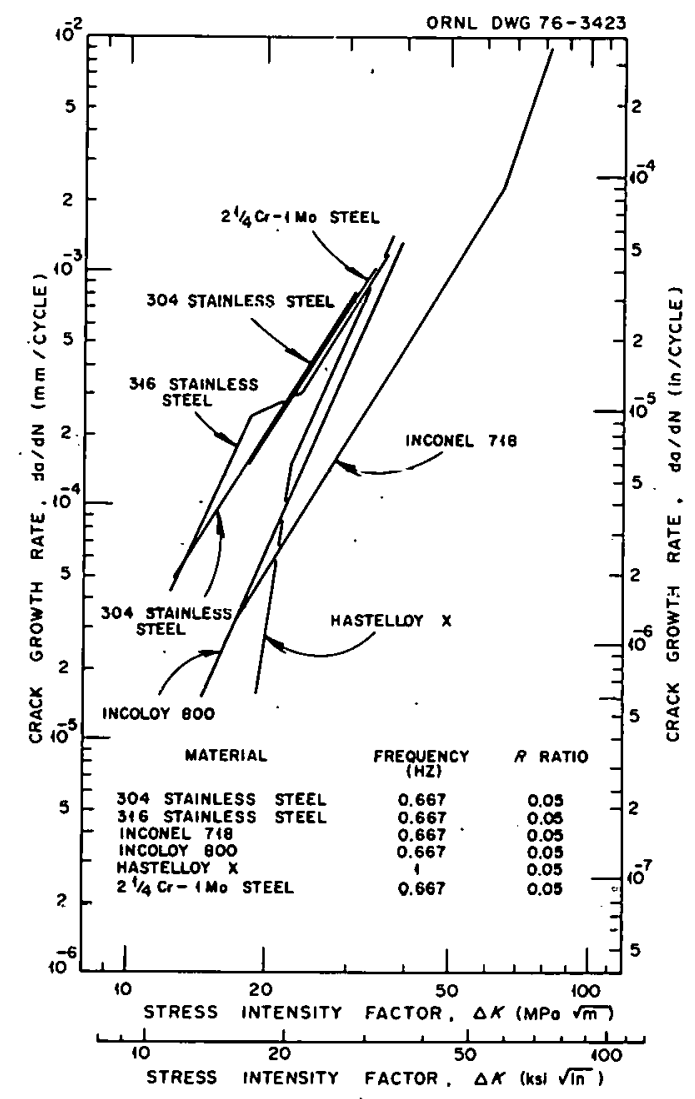

Fig. 30. Comparison of Fatigue Crack Growth Behavior of Several Candidate Structural Materials For Use in the HTGR at. $538^{\circ} \mathrm{C}\left(1000^{\circ} \mathrm{F}\right)$.

solution-hardened alloy and as such is not expected to show large changes in mechanical properties at temperatures appropriate to HTGR dcsign. However, the presence of molybdenum, chromium, and tungsten within the lattice may contribute to precipitation of carbides after extended periods of exposure. In an effort to determine the long-term elevatedtemperature aging response of this material, samples are being exposed to high temperatures of interest to HTGR design. Following aging exposure in the unstressed conditions, tensile, creep and fatigue tests along with metallographir examination will be used to determine the magnitude and cause of any changes found. No data are yet available from this part of the program. ${ }^{48-51}$

${ }^{48}$ E. L. Wagoner, "Physical Metallurgy and Mechanical Properties of Hastelloy X," Haynes Stellite Company, Division of Union Carbide Corporation, Kokomo, Indiana, 1961.

${ }^{49}$ D. A. Yablonski, "High Temperature Fatigue rrark Propagation Behaviur of Two Superalloys," Master's Thesis, Massachusetts Institute of Technology, 1976.

${ }^{50} \mathrm{G}$. W. Titus and W. L. Clarke, Jr., "Compatibility of Reactor Materials with High Temperature Gases," Nucl. Eng. Des. 24: 125-44 (1973).

${ }^{51}$ F. A. Comprelli, High-Temperature Tensize Properties of Selected A7.loys after Prolonged Thermal Exposure, General Electric Co., GEAP-4794 (1965). 
A number of investigators have reported changes in the roomtemperature tensile properties of Hastelloy $\mathrm{X}$ following various aging treatments at elevated temperatures. Typical changes in selected tensile properties are indicated in Fig. 31. The data trend lines indicate that at temperatures in excess of about $649^{\circ} \mathrm{C}\left(1200^{\circ} \mathrm{F}\right)$, thermal aging may result in an initial increase or decrease in room-temperature strength. Prolonged aging treatments apparently reduce strength levels below those of the virgin material. Comprelli ${ }^{5}$ has reported that increases in room-temperature strength and reduction in elongation below $15 \%$ following aging at as low a temperature as $566^{\circ} \mathrm{C}\left(1050^{\circ} \mathrm{F}\right)$ can occur. These changes are due to the changes in microstructure. Wagoner ${ }^{48}$ has reported that aging over the temperature range 649 to $1038^{\circ} \mathrm{C}$ (1200 to $1900^{\circ} \mathrm{F}$ ) resulted in the formation of grain boundary and matrix carbides of various types, including $\mathrm{M}_{6} \mathrm{C}, \mathrm{M}_{6} \mathrm{C}^{-}, \mathrm{M}_{23} \mathrm{C}_{6}$, and an " $\mathrm{X}$ " phase. Comprelli reported also minor amounts of the $\mathrm{AB}_{2}$-type Laves phase, while Titus and Clarke ${ }^{0}$ have also reported the presence of sigma and mu phases in this material subsequent to aging.

Changes of the type indicated above must be further quantified as to their impact on mechanical properties for HTGR design.

\section{Helium Corrosion}

Hastelloy $\mathrm{X}$ shows superior resistance to oxidation in air, perhaps because of the unique oxidation-resistant spinel that forms as the outer layer of a duplex oxide. The long-term behavior of this material in nonoxidizing environments, however, where carburization may occur, needs to be determined. Further, static and dynamic stresses will be imposen that may influence oxidation resistance. Therefore, the surfaces of specimens are being examined as a part of this program fulluwlus creep and fatigue testing. Only limited information, however, is currently available. Figures 32 and 33 show some typical photomicrographs of specimens following creep-rupture testing in helium. As expected, oxidation not only depends on the temperature but also on the stress. Figure 32 shows the specimen from test 16031 [152 $\mathrm{MPa}(22 \mathrm{ksi}), 760^{\circ} \mathrm{C}$

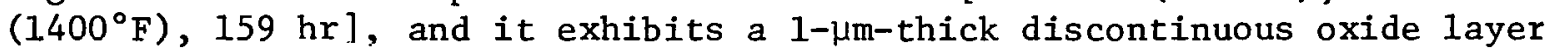
on the surface and many 40- to 50- $\mu \mathrm{m}$-deep grain boundary penetrations in the stressed (gage) section of the specimen. The surface of the lower stressed section of the specimen (at the shoulder) was covered with a smooth, green continuous $1-\mu \mathrm{m}$-thick oxide, and there was no indication of grain boundary attack. Figure 33 shows photomicrographs from test No. $16054\left[62 \mathrm{MPa}(9 \mathrm{ksi}), 871^{\circ} \mathrm{C}\left(1600^{\circ} \mathrm{F}\right), 554 \mathrm{hr}\right]$. Here the surface film was very thin $(<1 \mu \mathrm{m})$ at the stressed part of the specimen, and there were only few 20- to 30- $\mu$ m-deep penetrations. At the unstressed part of the specimen, there was also a very thin oxide layer, and there was no indication of oxidation attack. 

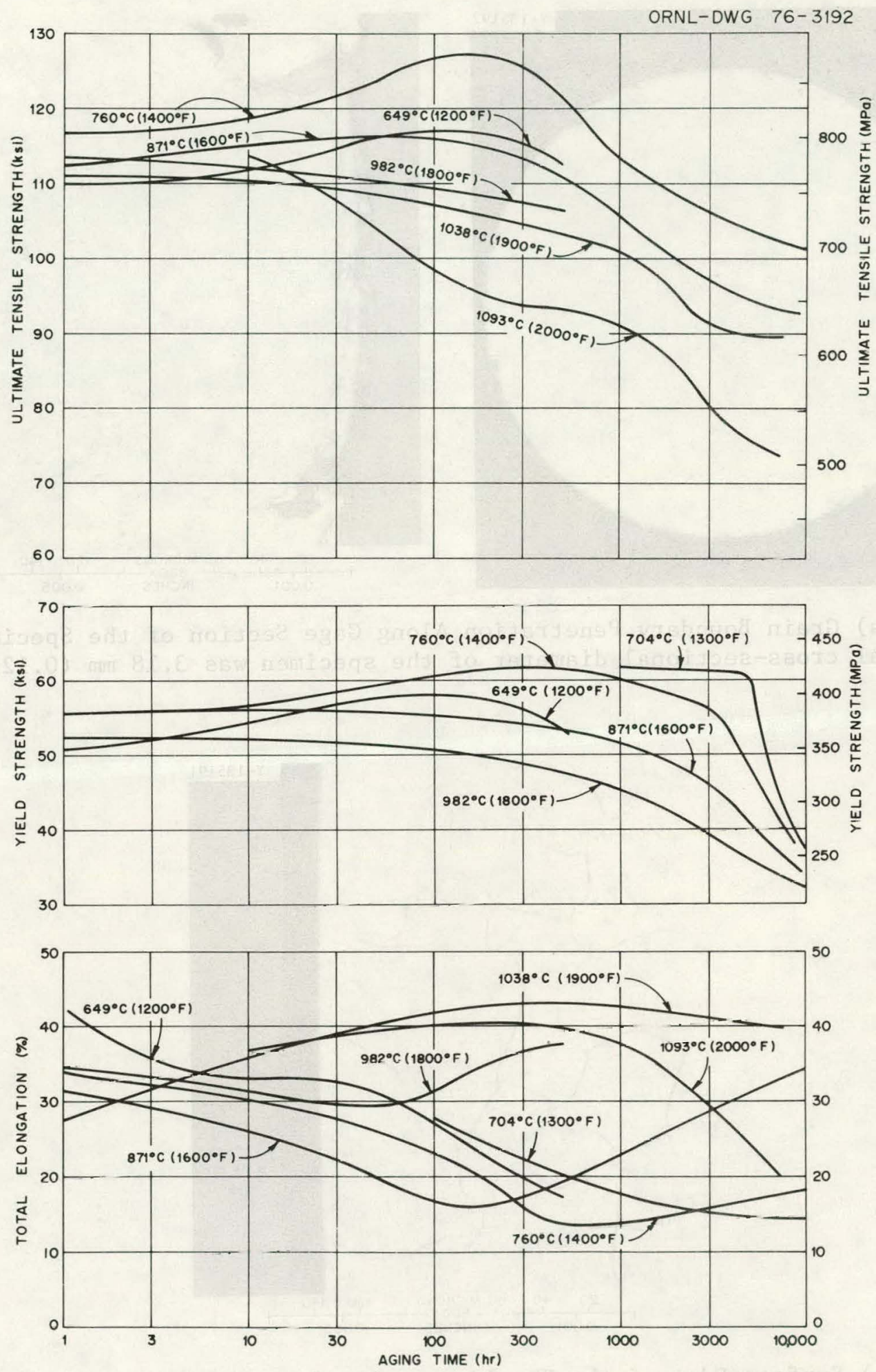

Fig. 31. Influence of Thermal Aging Time (In Air) at Several Temperatures on the Room-Temperature Tensile Properties of Hastelloy $\mathrm{x}$. 

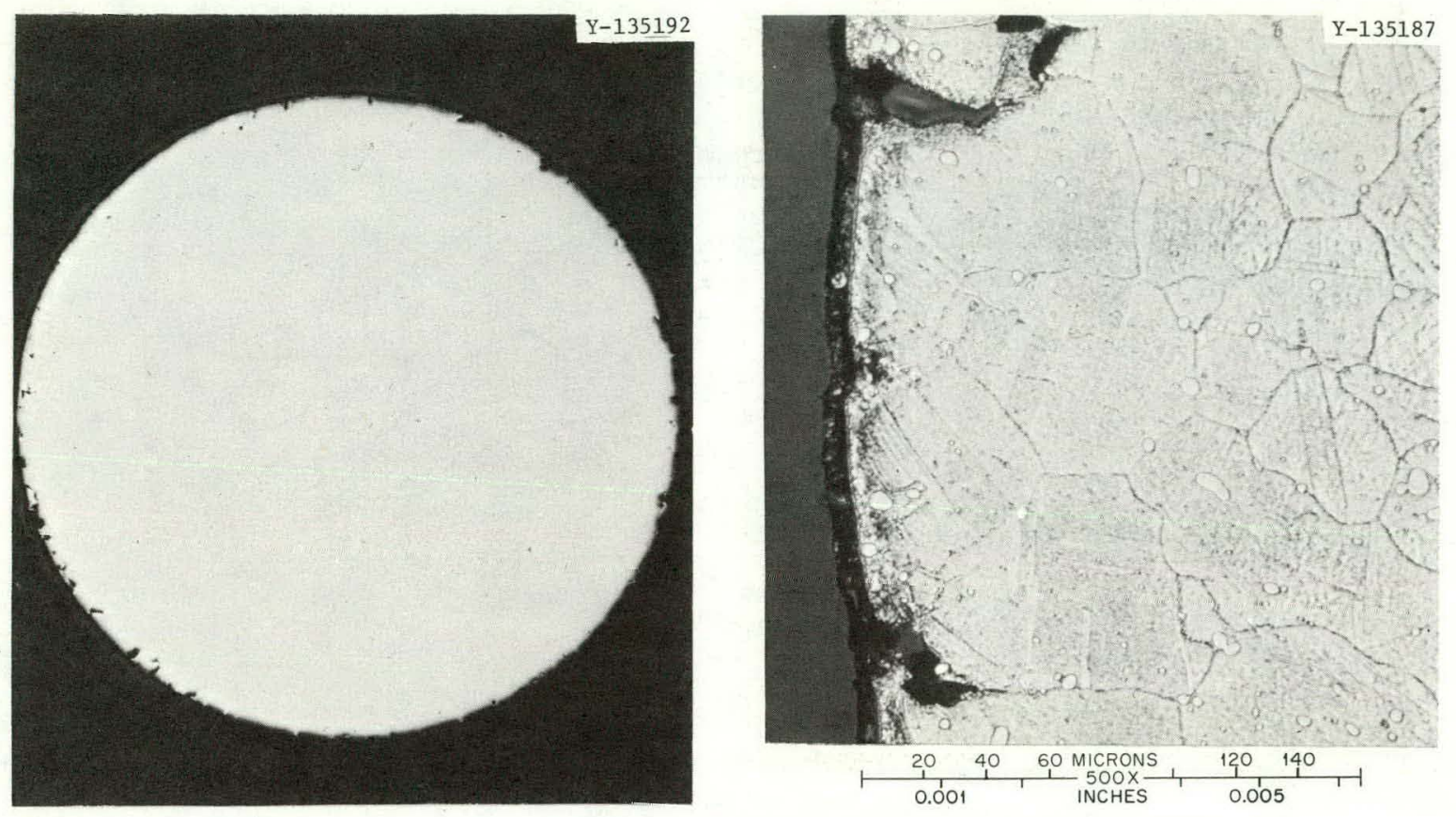

(a) Grain Boundary Penetration Along Gage Section of the Specimen. Original cross-sectional diameter of the specimen was $3.18 \mathrm{~mm}$ ( $0.125 \mathrm{in}$.).

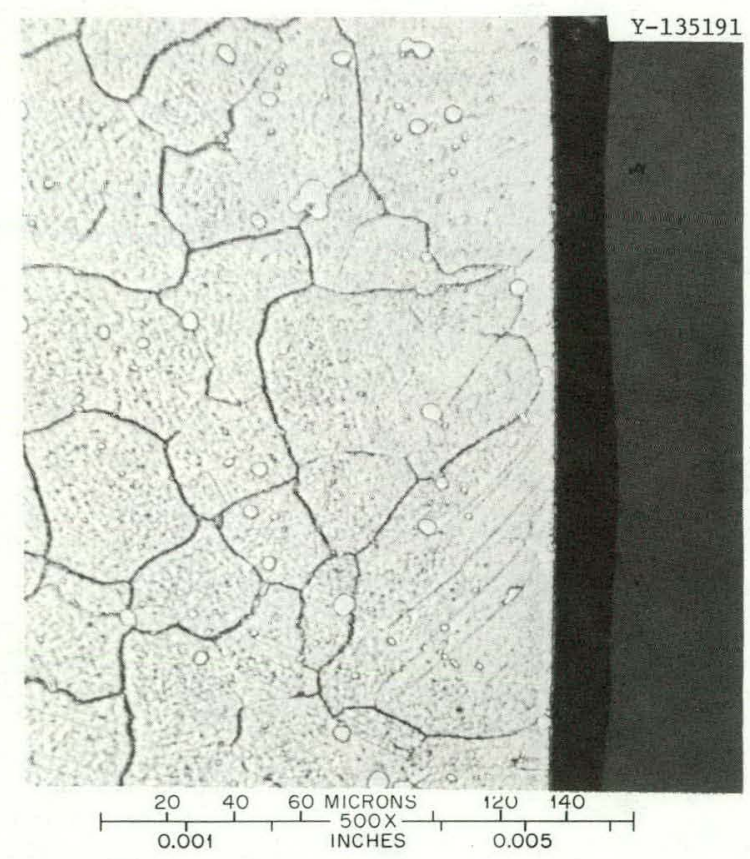

(b) Surface Edge of the Shoulder or Low Stressed Region of the Specimen.

Fig. 32. Photomicrographs of the Cross Section of Test Specimen 16031 stressed at $152 \mathrm{MPa}(22 \mathrm{ksi})$ at $760^{\circ} \mathrm{C}\left(1400^{\circ} \mathrm{F}\right)$. Specimen failed after $159 \mathrm{hr}$. 

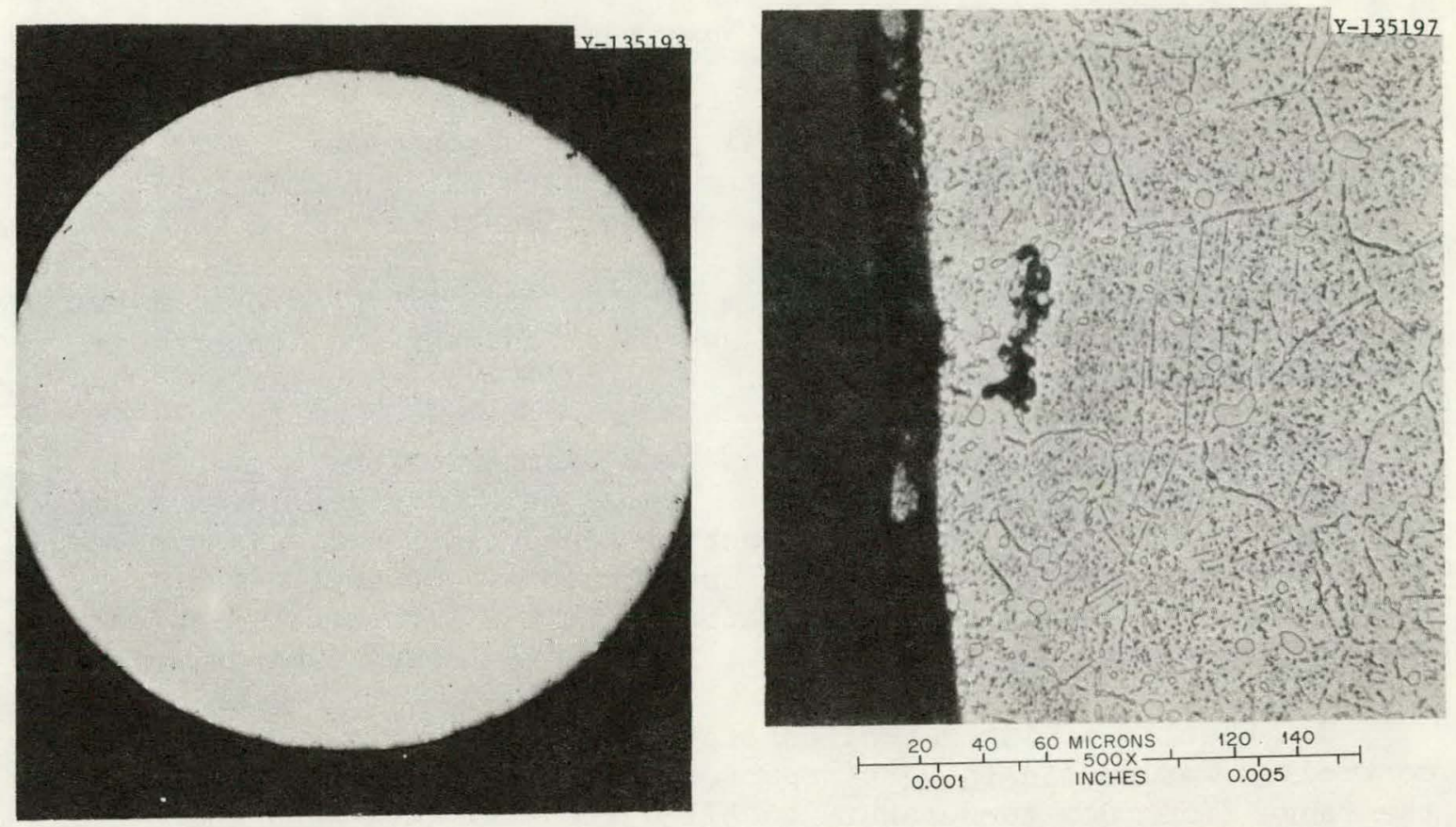

(a) Surface Cross Section Along Gage Section of the Specimen. Original cross-sectional diameter of the specimen was $3.18 \mathrm{~mm}$ (0.125 in.).

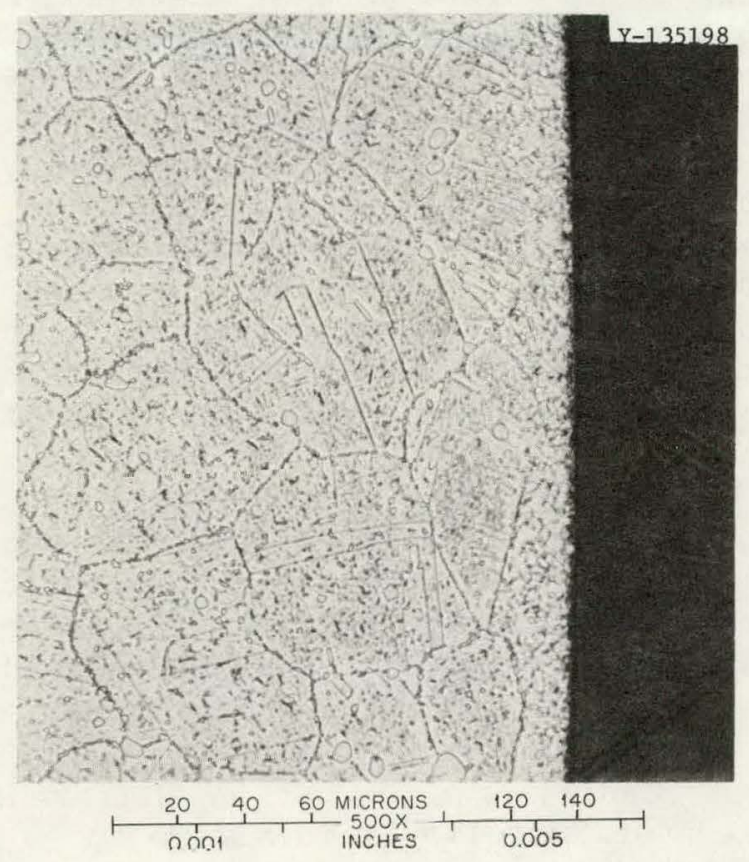

(b) Surface Edge of the Shoulder or Low Stressed Region of the Specimen.

Fig. 33. Photomicrographs of the Cross Section of Test Specimen 16054 Stressed at $62 \mathrm{MPa}(9 \mathrm{ksi})$ at $871^{\circ} \mathrm{C}\left(1600^{\circ} \mathrm{F}\right)$ for $554 \mathrm{hr}$. 
Results from interim mechanical property tests conducted to date on Hastelloy $\mathrm{X}$ at elevated temperatures in both air and helium with controlled impurity levels indicate the following:

1. A minimum in the short-term tensile ductility, as determined by reduction-of-area measurements, was observed over the temperature range 500 to $750^{\circ} \mathrm{C}\left(930\right.$ to $\left.1380^{\circ} \mathrm{F}\right)$.

2. Creep-rupture and creep data are available from tests that have been extended to about $6500 \mathrm{hr}$. These data were generated from specimens tested in helium with impurity concentration levels expected to be prototypic of HTGR operating environments. Creep-rupture results are comparable to those available in the literature, indicating, for the test times employed to date, little or no environmental effect.

3. Results of isothermal continuous-cycling fully reversed straincontrolled fatigue tests were reported. Increasing the temperature over the range from room temperature to $871^{\circ} \mathrm{C}\left(1600^{\circ} \mathrm{F}\right)$ decreased the cyclic life (cycles to failure), with the largest reduction occurring between room temperature and $649^{\circ} \mathrm{C}\left(1200^{\circ} \mathrm{F}\right)$.

4. Comparisons were made of the best-fit curves through the fully reversed strain-controlled fatigue data of Hastelloy $X$ and several other alloys used or proposed for use as reactor structural alloys. These alloys included types 304 and 316 stainless steel, Inconel alloy 718, $21 / 4 \mathrm{Cr}-1$ Mo steel (annealed), and Incoloy alloy 800. Comparisons were made from room temperature to $649^{\circ} \mathrm{C}$. These alloys tended to genera11y exhibit similar low-cycle fatigue lifetimes (as determined by comparing cycles to failure for a yiven otrain range): however, highcycle fatigue behavior was clearly dependent upon the short-term tensile strength, with Inconel alloy 718 showing the best high-cycle fatigue resistance and Hastelloy $X$ the second best. Differences in high-cycle fatigue resistance between these materials were accentuated by increasing the temperature.

5. Hold periods introduced during either the peak tension or compression, or both, portions of the strain-controlled cycle were found to decrease the cycles to failure of Hastelloy $X$ fatigued in air at $871^{\circ} \mathrm{C}$. Interim results indicate that compressive holds are more detrimental than tensile hold periods of equivalent duration.

6. For the test conditions examined, no difference was found between the crack growth rates of Hastelloy $X$ in air vs those in simulated HTGR primary coolant. This might be expected because of the excellent oxidation resistance of this material over the temperature range studied. If HTGR helium does affect the fatigue crack propagation rate behavior of Hastelloy $\mathrm{X}$, it will be at higher temperatures and/or lower cyclic frequencies than those investigated to date. 
7. Varying the test specimen geometry was shown to have an effect on the fatigue crack growth rate of Hastelloy $\mathrm{X}$ tested in air. An adequate explanation of this behavior has not been made to date.

8. The fatigue crack growth rate increases monotonically with increasing temperature over the range investigated.

9. Room-temperature tensile test results available from the literature were discussed and compared with those conducted on Hastellloy $\mathrm{X}$ that had been aged for various times and temperatures. Aging at temperatures at or in excess of about $566^{\circ} \mathrm{C}\left(1050^{\circ} \mathrm{F}\right)$ generally results in an initial increase in room-temperature strength and loss of some ductility, followed by a decrease in strength. Additional elevated-temperature tests conducted on material aged for times in excess of $10,000 \mathrm{hr}$ are recommended.

\section{ACKNOWLEDGMENTS}

The authors gratefully acknowledge the following personnel for their assistance in conducting the tests reported herein: E. Bolling, L. K. Egner, E. B. Patton, Jr., C. O. Stevens, W. B. Johnson, and R. F. Eaves. We also express our appreciation to R. B. Parker for editing the document and to Collene Trammell for typing the manuscript. 
THIS PAGE

\section{WAS INTENTIONALLY LEFT BLANK}


APPENDIX 
THIS PAGE

\section{WAS INTENTIONALLY LEFT BLANK}


Calculation of Equations Defining Fatigue Behavior of Several Materials

Given below are the equations defining cycles to failure for various strain ranges for several materials compared with Hastelloy $X$ in Figs. 21-23. The equations give best-fit lines through straincontrolled data generated at a strain rate of $4 \times 10^{-3} / \mathrm{sec}$.

\section{$21 / 4 \mathrm{Cr}-1$ Mo steel, annealed}

Cycles to failure $\left(N_{f}\right)$ can be expressed as a function of total strain range $\left(\Delta \varepsilon_{t}, \%\right)$ by

$$
\log N_{f}=\alpha_{0}+\alpha_{1} \log \Delta \varepsilon_{t}+\alpha_{2}\left(\log \Delta \varepsilon_{t}\right)^{2}+\alpha_{3}\left(\log \Delta \varepsilon_{t}\right)^{3} \text {, }
$$

where $\alpha_{0}, \alpha_{1}, \alpha_{2}, \alpha_{3}$ are unknown constants estimated by the method of least squares:

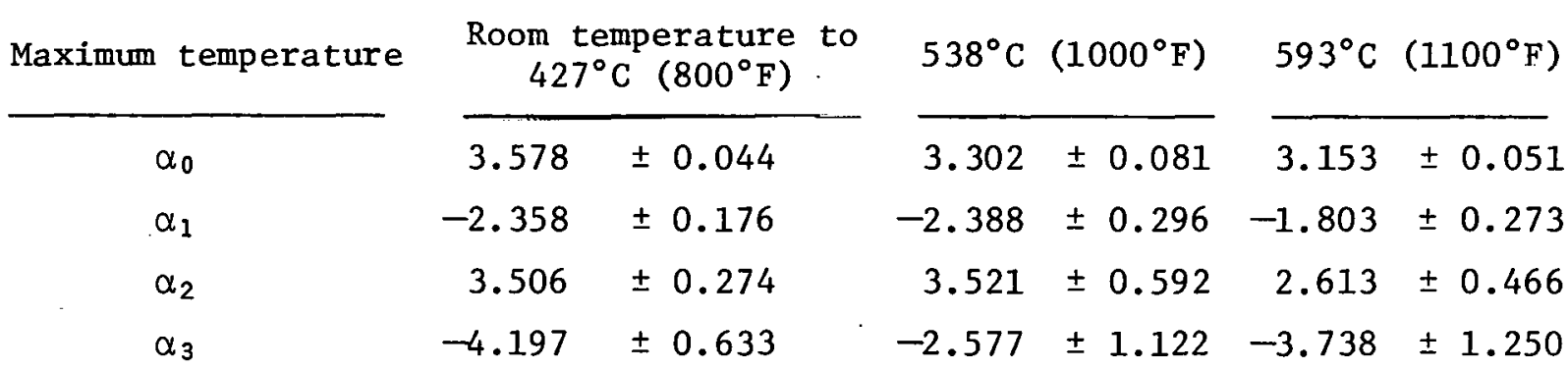

Applicable for cycllc strain rates $\approx 4 \times 10^{-3} / \mathrm{sec}$.

Applicable product forms: plate, pipe, bar in the annealed or isothermally annealed condition.

Data collected conformed to the following limitations:
Carbon content:
$0.07-0.15$ wt \%

Chromium content.

$2.0-2.5$ wt $\%$

Molybdenum content: $0.9-1.1$ wt \%

Minimum room temperature ultimate tensile strength: $414 \mathrm{MPa}$ (60 ksi) Minimum room temperature $(0.2 \%$ offset) yield strength: $207 \mathrm{MPa}$ (30 ksi)

Notes: No attempts were made to correct for the effects of mean strain or stress.

Except for minimum carbon, these restrictions are a subset of those given in the Nuclear Systems Materials Handbook under ASME Spec. SA-336-F22A and SA-387-22-C1.2. Other applicable specifications permit either a wider range in chemical composition or greater minimum strength values. The minimum carbon content of $0.07 \%$ is in accordance with ASME Sect. III for components in service at about $371^{\circ} \mathrm{C}\left(700^{\circ} \mathrm{F}\right)$. 
Inconel alloy $718,954^{\circ} \mathrm{C}$ solution annealed

Room temperature

$$
\begin{aligned}
\log N_{f}= & 4.317-4.184 \log \Delta \varepsilon_{t}+3.295\left(\log \Delta \varepsilon_{t}\right)^{2} \\
& -2.562\left(\log \Delta \varepsilon_{t}\right)^{3},
\end{aligned}
$$

$538^{\circ} \mathrm{C}\left(1000^{\circ} \mathrm{F}\right):$

$$
\begin{aligned}
\log N_{f}= & 4.590-8.673 \log \Delta \varepsilon_{t}+12.178\left(\log \Delta \varepsilon_{t}\right)^{2} \\
& -7.048\left(\log \Delta \varepsilon_{t}\right)^{3}, \\
649^{\circ} \mathrm{C}\left(1200^{\circ} \mathrm{F}\right): & \\
\log N_{f}= & 4.082-7.872 \log \Delta \varepsilon_{t}+12.364\left(\log \Delta \varepsilon_{t}\right)^{2} \\
& -8.494\left(\log \Delta \varepsilon_{t}\right)^{3}
\end{aligned}
$$

$\Delta \varepsilon_{t}$ in $\%$

Type 316 stainless steel

Room temperature:

$\Delta \varepsilon_{t}=\Delta \varepsilon_{p}+\Delta \varepsilon_{e}$

$\log \Delta \varepsilon_{p}=-0.176-0.499 \log N_{f}$

$\log \Delta \varepsilon_{e}=-1.75-0.179 \log N_{f}$

${ }^{\Delta} \varepsilon_{p, e}$

$649^{\circ} \mathrm{C}\left(1200^{\circ} \mathrm{F}\right):$

$\Delta \varepsilon_{t}=\Delta \varepsilon_{p}+\Delta \varepsilon_{e}$

$\log \Delta \varepsilon_{p}=-0.264-0.560 \log N_{f}$

$(A-7)$ 
$\log \Delta \varepsilon_{e}=-1.91-0.153 \log N_{f}$

$\Delta \varepsilon_{\rho, e}$

Type 304 stainless steel

Room temperature:

$\Delta \varepsilon_{t}=\Delta \varepsilon_{p}+\Delta \varepsilon_{e}$

$\log \Delta \varepsilon_{\rho}=-0.608-0.403 \log N_{f}$

$\log \Delta \varepsilon_{e}=-1.30-0.303 \log N_{f}$

$\Delta \varepsilon_{\rho, e}$

538 and $566^{\circ} \mathrm{C}\left(1000\right.$ and $\left.1050^{\circ} \mathrm{F}\right)$ :

$\Delta \varepsilon_{t}=\Delta \varepsilon_{p}+\Delta \varepsilon_{e}$

$\log \Delta \varepsilon_{\rho}=1.67-0.515 \log N_{f}$

$\log \Delta \varepsilon_{e}=0.0704-0.149 \log N_{f}$

${ }^{\Delta \varepsilon_{\rho, e}}$ in $\%$

$649^{\circ} \mathrm{C}\left(1200^{\circ} \mathrm{F}\right):$

$\Delta \varepsilon_{t}=\Delta \varepsilon_{p}+\Delta \varepsilon_{e}$

$\log \Delta \varepsilon_{\rho}=0.113-0.681 \log N_{f}$

$\log \Delta \varepsilon_{e}=-1.88-0.188 \log N_{f}$

$\Delta \varepsilon_{\rho, e}$ not in $\%$ 
Austenitic stainless steels, types 304, 310, 316, 347, and 348 (ref. 1)

Room temperature to $427^{\circ} \mathrm{C}\left(800^{\circ} \mathrm{F}\right)$ :

$\Delta \varepsilon_{t}(\%)=64.0 N_{f}^{-0.5}+0.223$

Incoloy alloy 800 , grades 2 and $\mathrm{H}$

Room temperature:

$$
\begin{aligned}
\log N_{f}= & 3.903-2.903 \log \Delta \varepsilon_{t}+0.831\left(\log \Delta \varepsilon_{t}\right)^{2} \\
& -0.177\left(\log \Delta \varepsilon_{t}\right)^{3}
\end{aligned}
$$

$538^{\circ} \mathrm{C}\left(1000^{\circ} \mathrm{F}\right):$

$\log N_{f}=3.485-2.391 \log \Delta \varepsilon_{t}+2.272\left(\log \Delta \varepsilon_{t}\right)^{2}$

$$
-3.009\left(\log \Delta \varepsilon_{t}\right)^{3}
$$

$649^{\circ} \mathrm{C}\left(1200^{\circ} \mathrm{F}\right):$

$\log N_{f}=3.191-2.099 \log \Delta \varepsilon_{t}+1.495\left(\log \Delta \varepsilon_{t}\right)^{2}$

$$
-1.295\left(\log \Delta \varepsilon_{t}\right)^{3}
$$

$\Delta \varepsilon_{t}$ in $\%$

AISI 1010 steel

Room temperature:

$\log N_{f^{\prime}}=3.710-2.706 \log \Delta \varepsilon_{t}+1.910\left(\log \Delta \varepsilon_{t}\right)^{2}$

$538^{\circ} \mathrm{C}\left(1000^{\circ} \mathrm{F}\right):$

$\log N_{f}=3.320-1.410 \log \Delta \varepsilon_{t}+1.670\left(\log \Delta \varepsilon_{t}\right)^{2}$

${ }^{1}$ Personal communication from C. E. Jaske, Battelle Columbus Laboratory, June $16,1975$. 
$649^{\circ} \mathrm{C}\left(1200^{\circ} \mathrm{F}\right):$

$\log N_{f}=3.250-1.280 \log \Delta \varepsilon_{t}+0.681\left(\log \Delta \varepsilon_{t}\right)^{2}$

$\Delta \varepsilon_{t}$ in $\%$ 
THIS PAGE

WAS INTENTIONALLY

LEFT BLANK 
ORNL/TM-5405

Distribution

Category UC-77

\section{INTERNAL DISTRIBUTION}

1-2. Central Research Library

3. Document Reference Section

4-13. Laboratory Records Department

14. Laboratory Records, ORNL RC

15. ORNL Patent Office

16. R. J. Beaver

17. M. K. Booker

18-27. C. R. Brinkman

28. J. P. Callahan

29. D. A. Canonico

30. J. H. Coobs

31. J. M. Corum

32-34. W. R. Corwin

35. F. L. Culler

36. J. E. Cunningham

37. J. H. DeVan

38-40. J. R. DeStefano

41. R. G. Donnelly

42. G. G. Fee

43. B. L. Greenstreet

44. J. C. Griess, Jr.

45. J. P. Hammond

46. W. O. Harms

47-49. M. R. Hill

50. J. M. Holmes

51. H. Inouye

52. P. R. Kasten

53. J. F. King

54. R. T. King

55. K. L. KIueh

56. K. C. Liu
57. C. T. Liu

58. E. L. Long, Jr.

59. A. L. Lotts

60. A. P. Malinauskas

61. W. R. Martin

62. H. E. McCoy

63. H. C. McCurdy

64. C. J. McHargue

65. R. K. Nanstad

66. J. P. Nichols

67. P. Patriarca

68. S. Peterson

69. H. Postma

70. C. E. Pugh

71. P. L. Rittenhouse

72. T. K. Roche

73. R. Salmon

74. J. P. Sanders

75. J. L. Scott

76. V. K. Sikka

77. G. M. Slaughter

78-85. J. P. Strizak

86. D. B. Trauger

87. J. R. Weir, Jr.

88. G. D. Whitman

89. P. M. Brister (consultant)

90. John Moteff (consultant)

91. Hayne Palmour III (consultant)

92. J. W. Prados (consultant)

93. N. E. Promisel (consultant)

94. D. F. Stein (consultant) 
EXTERNAL DISTRIBUTION

95-96. - USERDA DIVISION OF NUCLEAR RESEARCH AND APPLICATIONS, Washington, DC 20545

Director

97-98. USERDA DIVISION OF NUCLEAR FUEL CYCLE AND PRODUCTION, Washington, DC 20545

99-100. USERDA OAK RIDGE OPERATIONS OFFICE, P.0. BOX E, Oak Ridge, TN 37830

Director, Reactor Division

Director, Research and Technical Support Division

101-267. USERDA TECHNICAL INFORMATION CENTER, Office of Information Services, P.0. Box 62, Oak Ridge, TN 37830

For distribution as shown in TID-4500 Distr1but1on Category, UC-7? (Gas-Cooled Reactor Technology) 